Historic, Archive Document

Do not assume content reflects current scientific knowledge, policies, or practices. 



\section{SEEDS of the}

\section{WILSON QUALITY \\ For Your 1926 Garden}

Especially

Wilson's Evergreen Lawn Seed

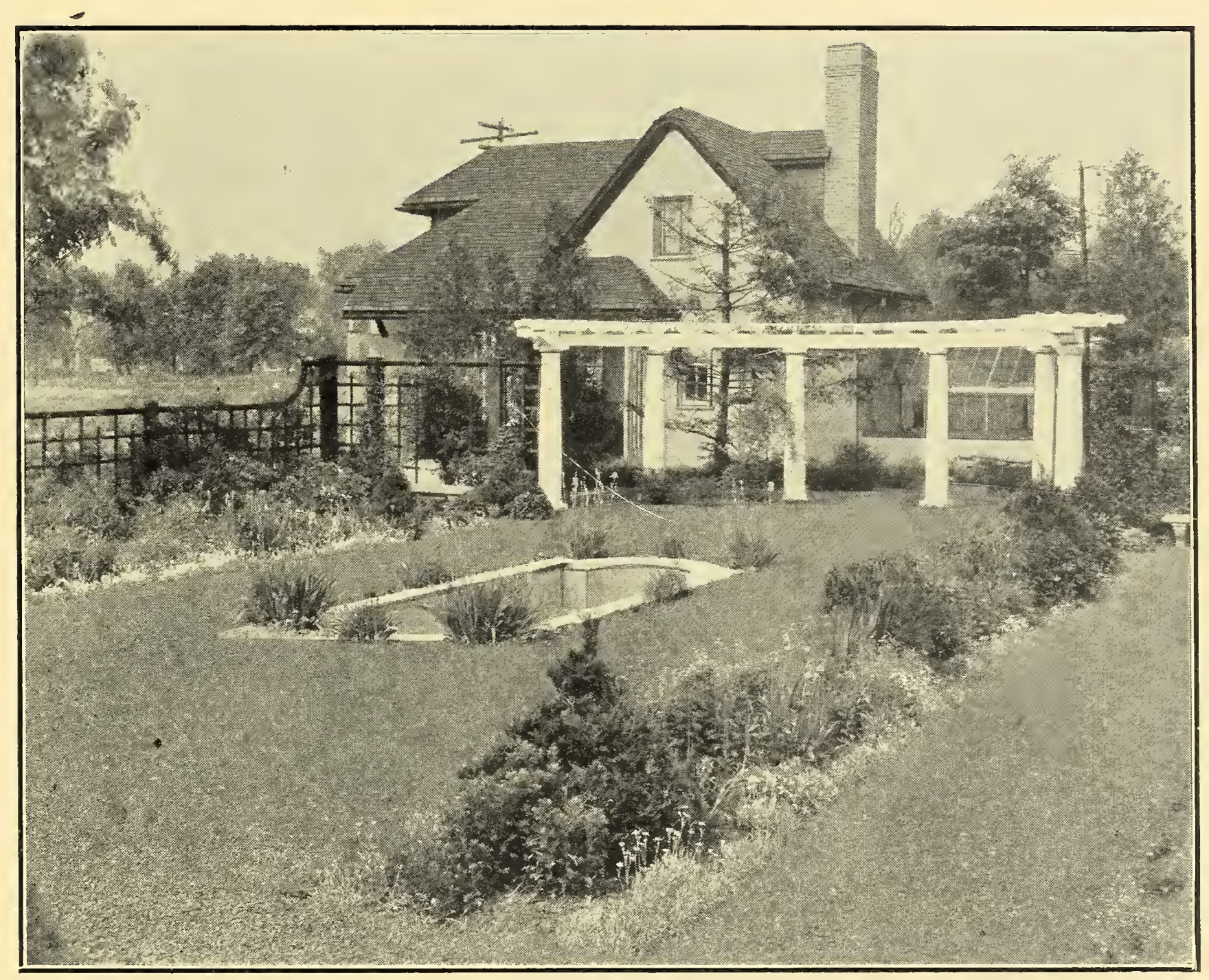

A WILSON EVERGREEN LAWN (See page 3)

\section{J.J.WILSON SEED COMPANY, Incorporated Your Friendly Seed Store}

79 Orange Street NEWARK, NEW JERSEY Close to Broad St. 




\section{HOW TO MAKE A LAWN}

T.

HE production of a good lawn is not difficult. Dig the soil about 6 inches deep, but only when it is dry. Turn each clod completely over, striking it with the back of the fork to break it Remove all stones, sticks, and rubbish. Scatter Wilson's 4 Seasons Grass Fertilizer on the dug earth 1 ton per acre or 1 pound to each 25 square feet Draw a rake back and forth until the soil is smooth and friable. Sow wilson's Evergreen Iraw seed at the minimum rate of 120 pounds per acre, or 1 pound (nearly 2 quarts) to each 200 square feet. Double the quantity when turf is needed quickly. Select a day when no wind is blowing; divide the seed into two portions and sow the land twice to insure its even covering; stir the contents of the bag now and again. When you have sown the seed, rake once more, but lightly. Roll the seeded area, but should rain fall before the work is completed, defer the rolling until the soil has dried.

How long will it take to produce a Lawn?

This varies with the time of year, quality of soil, rainfall, etc Under very favorable conditions the young seedlings show through in less than ten days and the whole area looks green in about two weeks; wait four weeks more before walking on the grass except to mow and roll it.

When is the best time to make a Lawn?

Early spring and late summer are the best, but seed will usually grow quite well if sown at any time of the year except July.

Will the above directions hold on poor land?

Before commencing work on poor soil, use Pulverized Poultry or Sheep Manure at the rate of 2 tons to the acre or 1 pound to each 10 square feet. Do not attempt to grow a lawn on excavated soil, subsoil, or "fill" without first applying manure, digging, then adding at least an inch of top-soil; two or three if possible. Then apply 4 Seasons Grass Fertilizer, and proceed as suggested.

How about moist, sour soil?

Spread hydrated or ground lime at the rate of 2 tons per acre or 1 pound to each 10 square feet: then follow directions as set forth in first paragraph of this article.

Should I water the new Lawn?

Best not for the first two or three weeks, as it is likely to do more harm than good. Later when the grass has well started, it should b watered in dry weather: use an approved type of sprinkler and scak once every week.

\section{What after-care is needed?}

As soon as the young grass is 2 inches high begin cuttîng it and keep it regularly mown: roll it now and then with a medium weight roller (about $200 \mathrm{lbs}$.) and water during dry weather.

\section{How about Weeds?}

wilson's Seeds are as free from weeds as care and modern machinery can make them. All soils, however, contain weed seeds-some more than others-and many of these start to grow with the grass. Close cutting will kill most, but the few that remain must be taken out, and the holes filled with good soil in which you have mixed some grass seed.

\section{How about White Clover?}

We include Clover in our Evergreen Iawn Seed, because Clover is a valuable source of nitrogen and because it resists drought, etc. I forms a splendid turf and goes a long way toward the elimination of weeds.

Is "Wilson's Evergreen" the best seed to use?

No seeds are purer and no seeds grow more vigorously than the grass seeds in Wilson's Evergreen, which is a mixture of five distinct varieties, and for the finest lawns cannot be surpassed. For shade and special conditions use the mixtures described on page 3 .

Sow Wilson's Evergreen on open lawns and Wilson's "Shady Spot" Evergreen on shaded lawns.

Top-dress every Fall and Spring with Four Seasons, the ordorless, organic, fool-proof plant food and stimulant. See page 5. 


\section{THIRTEENTH YEAR OF YOUR FRIENDLY SEED STORE'S \\ UNUSUAL SEED SERVICE}

THIS IS OUR THIRTEENTH ANNUAL CATALOG. Many of OUR FRIENDS have been with us since we started in 1913, whilst some have only found us recently. "To all we extend our hearty thanks for favors and courtesies shown us and we invite YOU, who do not yet know us, to become one of our large circle of FRIENDLY CUSTOMERS.

REMEMBER! The most accessible Seed Store in Newark is WILSON'S, 79 Orange Street, just a few steps in from Broad Street. Plenty of room for your car right before the door!

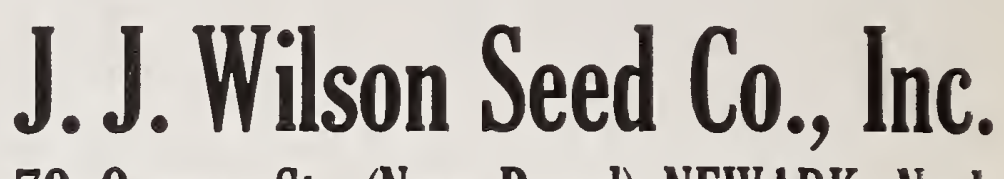
79 Orange St. (Near Broad) NEWARK, N. J. Phone HUMBOLDT 2477.

be sure to sign your name and give full address. All prices include cost of transportation, evcept where otherwise noted.

"Wilson's Seeds" are the best that can be grown-that's why we ask you to buy them.

\section{Wilson's "Quality" Fertilizers}

Delivered free within fifty miles of Newark.

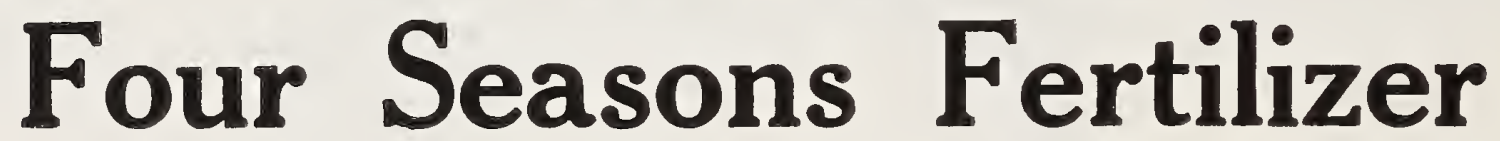

\section{'Used The Year Round'}

Nothing to equal it for lawns.

\section{A Natural Humus, Growth Stimulant and Plant Food.} Don't fail to read all about it on page 5 .

Special Complete Garden Fertilizer, High Grade. A quick-acting safe and reliable food and stimulant for all crops. 5 lbs, 35 cts. 10 lbs, 60 cts. 25 lbs. $\$ 1.35 ; 50$ lbs. $\$ 2.25 ; 100$ lbs. $\$ 4.25$.

Iawn Fertilizer. A high-grade plant food in available form. For top-dressing apply before a rain or wash in with a hose. 5 lbs. 35 cts.; 10 lbs. 60 cts.: $25 \mathrm{lbs}$. (for $20 \times 100$ feet) $\$ 1.35$; $50 \mathrm{lbs}$. (for $50 \times 100 \mathrm{ft}$.), $\$ 2.25 ; 100$ lbs. $\$ 4.25$.

Sheep Manure, Pulverized. Fine for mixing with potting soil, for lawns, etc For liquid use 3 lbs to 5 gals. water. 5 lbs. 40 cts.; 10 lbs. $70 \mathrm{cts}$. 25 lbs. $\$ 1.50 ; 50$ lbs. $\$ 2.50 ; 100$ lbs. $\$ 4.50$.

\section{POULTRY MANURE, PULVERIZED} Much Superior to Sheep Manure

For flowers, fruits, vegetables and for lawns. Produces quick growth, rapid development and enormous yields. 5 lbs. 40 cts.; 10 lbs. 70 cts.; 25 lbs. $\$ 1.50 ; 50$ lbs. $\$ 2.50 ; 100$ lbs. $\$ 4.50$.

Florists Special Tankage (Fine for Dahlias). For cabbage, cauliflower, corn and other crops of big surface growth. 5 lbs. 45 ets.; 10 lbs. 80 cts.; 25 lbs. $\$ 1.75 ; 50$ lbs. $\$ 3.00 ; 100$ lbs. $\$ 5.50$.

Potash Marl. A valuable plant food for vegetable crops, flowers and lawns. Odorless. For lawns use $200 \mathrm{lbs}$. to 1,000 square feet. $100 \mathrm{lbs}$. $\$ 3.50$.

Pure Bone Meal. Figh grade. Fine for rose culture and for plants of every kind. 5 lbs. 50 cts.; 10 1bs. 80 cts.; 25 lbs. $\$ 1.75 ; 50$ lbs. $\$ 3.00 ; 100$ $1 \mathrm{bs}$. $\$ 5.50$.

Nitrate of Soda. Do not apply until plants are above ground. Lb. 15 cts.; 5 lbs. 60 cts.; 10 lbs. $\$ 1.00 ; 25$ lbs. $\$ 2.00 ; 50$ lbs. $\$ 3.75 ; 100$ lbs. $\$ 7.00$. For liquid use $1 \mathrm{oz}$. ( 2 heaping teaspoons) to a gallon or 5 lbs. to 80 gallons of water. Price subject to change.

Plant Iime. Finely ground limestone. Best by far for all agricultural purposes. Apply at the rate of 10 pounds to 100 square feet, or 1 to $1 \frac{1 / 2}{\text { tons }}$ per acre. 5 lbs. 30 cts.; 10 lbs. 50 cts.; 25 lbs. $\$ 1.00 ; 50$ lbs. $\$ 1.50 ; 100$ lbs. $\$ 2.00$.

Stim-U-PlanT. Plant stimulant tablets.

Small size ( 30 tablets)

Medium size ( 100 tablets)

Large size (1,000 tablets)
By Mail. $\$ .30$ .80 3.65

\section{Insecticides and Remedies for Plant Diseases} TRANSPORTATION CHARGES gXTRA

Arsenate of Iead. (Powder.) For all leaf-eating insects. 1 lb. 45 ct's.; 5 lbs. $\$ 2.00$.

Ilcotine Sulphate (40\%). Destroys sucking insects, aphis on roses, etc. 1 oz. bottle 35 cts.; $1 / 21 \mathrm{~b}$. tins $\$ 1.25 ; 2$ lb. tins $\$ 3.50 ; 101 \mathrm{~b}$. tins $\$ 13.50$.

Bordeaux Mixture. For all fungous diseases. Powder, 1-1b. tin 45 cts.; 5-lb. tin $\$ 2.00$.

Bordeaux Iead. (Powder.) Safest spray for leafeating insects: prevents blight and fungus diseases. 1 lb. 45 cts.; 5 lbs. $\$ 2.00$.

Fish Oil Soap. For washing trees and destroying insects. Box about 1-1b. 25 cts.; 5 boxes for $\$ 1.00$.

salphar. For mildew on roses, etc. 1 lb, 15 cts. 5 lbs. 50 cts.; 10 lbs. 90 cts.

Crape Dust, Iammond's. For mildew on grapes, blight, etc. 1-lb. carton 40 cts.; 5 lbs. $\$ 1.00$.
Iime-Sulphur. For San Jose and other scale. (Dry.) Lb. 35 cts.; 5 lbs. $\$ 1.50 ; 10$ lbs. $\$ 2.25$.

slug shot, Hammond's. For destroying potato bugs. currant worms, ants, etc. Lb. 25 cts.; 5 lbs. 65 cts.; 10 lbs. $\$ 1.15 ; 25$ lbs. $\$ 2.50$.

Tobacco Dust. Lb. 15 cts.; 5 lbs. 60 cts.; 10 lbs $\$ 1.00 ; 25$ lbs. $\$ 2.00 ; 100$ lbs. $\$ 7.00$.

weed rxterminator, wilson's. Destroys weeds of all kinds on roadways, paths, gutters, tennis courts. 1 gal. makes 40 gals. by adding water. Quart 75 cts.; gal. $\$ 2.00 ; 5$ gals. $\$ 8.00$.

Worm Fradicator, Wilson's. Rids lawns of earth worms. Use 1 oz. to 3 gals. water. 8 ozs. bottle 50 cts.; gal. $\$ 4.00 ; 5$ gals. $\$ 17.50$.

wilson's O. K. Plant Spray. For rose bugs, red spider, thrips, aphis, etc. Fine dormant spray for grapes. $1 / 2$ pt'.35 cts.; qt. $\$ 1.00$; gal. $\$ 3.00$.

Sulpho-Tobacco soap. For green fiy on roses, etc Per 1/2-1b. box, 25 cts.; 1-1b. bars, $40 \mathrm{c}$ each. 


\section{Wilson's 4 Seasons Fertilizer The Perfect Plant Food}

A natural combination of Vegetable products which forms humus after decomposition. It feeds gradually and constantly and retains moisture wonderfully.

NO WEED SEEDS!

NO MUSS!!

NO ODOR!!!

(Cheaper than smelly weed-carrying manure)

\section{Will not burn the most tender foliage!!!!}

Discourages, therefore eventually eliminates, the most troublesome of all Lawn pests BROWN.SPOT - a fungus disease superinduced by the too continuous application of stable manure-destroying, as it does, more fine lawns than any other known cause.

\section{Such is the wonder fertilizer \\ 4 SEASONS}

used the year 'round for Greenhouses,

Gardens, Golf Courses and Lawns

\section{What Is 4 SEASONS Fertilizer?}

FOUR SEASONS FERTILIZER is repeated and most deservedly referred to by authorities on plant life as the "perfect plant food."

Nitrogen, phosphoric acid and potash, the essentials of perfect plant production, are present in finely balanced proportions in this wonderful fertilizer.

Carefully prepared and ready to use either mixed with the soil for potting or as a top dressing for gardens or lawns, FOUR SEASONS FERTILIZER is positively guaranteed not to "burn" the most tender foliage.

FOUR SEASONS FERTILIZER is equally fine for ferns, bulbs, shrubs, fruits and flowers, but espe cially for lawns. It gives seeds a strong start and produces sturdy, quick-growing plants.

FOUR SEASONS F'ERTILIZER can be used all year 'round, and you will enjoy using it. So different from animal manures, it has no odor.

\section{What men who know say about 4 SEASONS -the perfect plant food!}

\section{ANDREW BROWN}

Golf Professional and Greenskeeper Lido Country Club, Long Beach, N. Y.

Your FOUR SEASONS FERTILIZER is filling a long-felt want on the Golf Course, being a very efficient and easily handled grass food.

My experience has been that continual top dressings with stable manure compost has a tendency to feed up and spread the various fungus diseases in turf, and from actual tests on this course with your fertilizer the greens treated have shown a fine uniform growth, and have remained free of fungus. Taking into consideration the cost of handling and screening stable manure I find the "Four Seasons" fertilizer does not burn, is cheaper and more convenient besides being free from all weed seeds and risks of introducing fungus into the greens.

\section{Sincerely yours}

ANDREW BROWN,

Lido Golf Club, Long Beach.
LOUIS L. MILLER

Landscape Engineer and Architect Somerville, N. J.

August 7, 1924.

Some weeks ago I received the hundred pound bag of your fertilizer, for which I thank you very mucb.

We had a very weak piece of fairway and decided to try it out on it.. It so happened that a storm was rapidly approaching and we spread the fertilizer. Had no sooner finished than the storm broke, washing the fertilizer well into the grass roots. This weak spot rapidly picked up and became husky enough to withstand the present drought even better than the old well-established grass.

From the above I can highly recommend this product and feel when we are in the market we shall come to you.

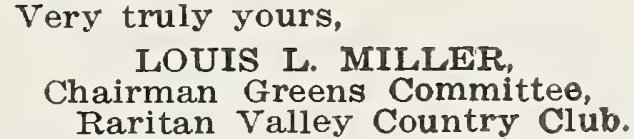

Mr. Miller did much of the landscape work on the DUKE ESTATE at Somerville, N. J.

\begin{tabular}{|c|c|cl|}
\hline 25 lbs. & $50 \mathrm{lbs}$. & $100 \mathrm{lbs}$. & Cloth bags. \\
\hline$\$ 1.50$ & $\$ 2.50$ & $\$ 4.00$ & If carried away. \\
\hline$\$ 1.75$ & $\$ 2.75$ & $\$ 4.50$ & Delivered. \\
\hline
\end{tabular}

We also have an $8 \mathrm{lb}$. paper bag for 50 cts but we do not deliver less than $25 \mathrm{lbs}$. 


\section{The Wilson Quality Vegetable Seeds}

Our Catalog Being Arranged Alphabetically Requires No Index

\section{ASPARAGUS SEEDS AND ROOTS}

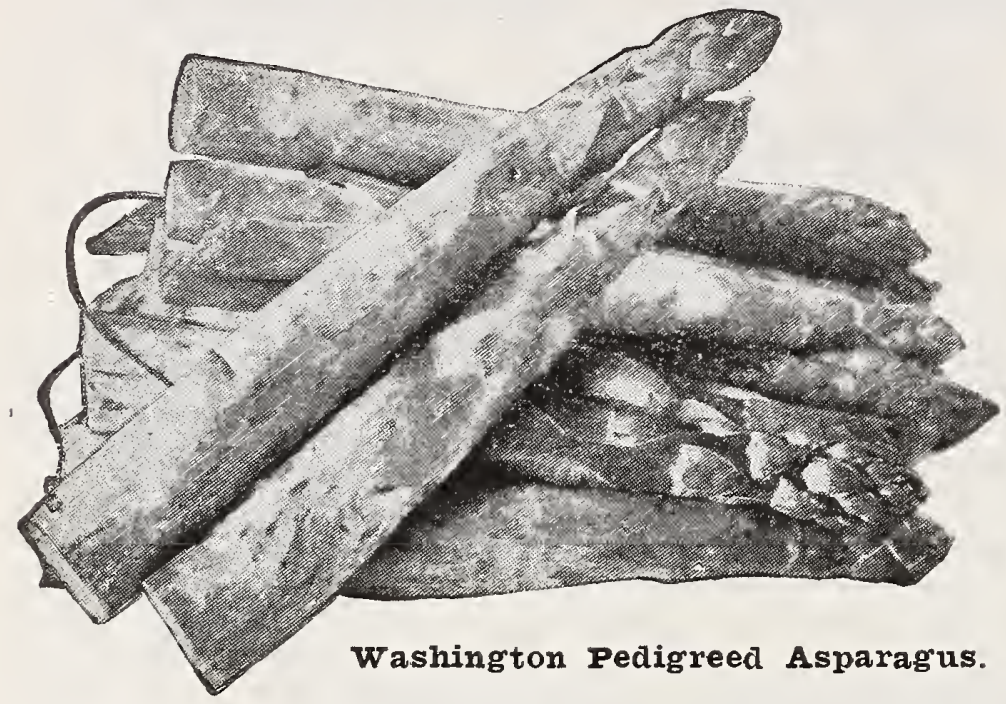

One ounce will sow a row 40 feet long and will produce about 600 plants; 5 lbs. to the acre; 150 roots to a bed $15 \times 50$ feet, or 8,000 to the acre.
CULTURE. Sow in March or April in rows 1 foot apart in well manured, rich sandy loam. When the plants are one or two years old, put them into permanent beds 3 to 4 feet apart, allowing from $1 \frac{1}{2}$ to 2 feet between the plants in the row. Cover tops firmly with 2 or 3 inches of soil. A dressing of salt at the rate of 8 ounces to the square yard is recommended every spring. On the approach of winter, cover with manure or straw.

WASHINGTON PEDIGREED ASPARAGUS. This

strain produces large straight shoots, dark green in color with heavy purple overtone. The tips are tight and firm. It is nearer to being rust-proof than any other variety. If you already have an Asparagus bed it will pay you to plant some of this variety and note the great improvement over the kind you are now growing.

Seed. Pkt. 10 cts.; oz. 30 cts.; $1 / 4$ lb. $\$ 1.00$; lb. $\$ 3.50$.

Roots. 2-year-old roots, 75 cts. for $25 ; \$ 2.50$ per 110 ; $\$ 20.00$ per 1,000 .

Prices of roots do not include cost of transpor. tation.

With vegetables at the prices they bring today, who says it doesn't pay to plant a garden?

\section{Brittle WILSON'S BEANS Tender}

We supply liberal packets of all Beans at $10 \mathrm{cts}$. each, postpaid.

\section{GREEN-PODDED BUSH BEANS}

2 lbs. will sow a row 150 feet long; 60 to $90 \mathrm{lbs}$. to the acre.

Mature in 40 to 50 days from germination. Average

height, 15 inches. Average yield, 125 to 150 bushels green pods to acre.

CULTURE-Start sowing the first week in May and for succession at intervals of two weeks until the latter part of August. Plant the Beans 2 ins. deep and 2 ins. apart in the row, the rows about 2 feet apart; hoe frequently up to the time of blossoming, but only when the vines are perfectly dry, always drawing the soil toward the rows. Avoid too deep cultivation, as any mutilation of the roots after plants come into bloom is liable to cause blosWill continue in bearing longer if the Beans are will continue in bearing longer if th

WILSON'S MASTERPIECE. Plant robust, strongly branching and rarely affected by rust, etc. Unsurpassed for greenhouse work. Pods 7 to 8 ins. long; broad, thick, flat. Tender and of exquisite flavor. For exhibition purposes it is without a peer. $1 / 2$ lb. 25 cts.; 1 lb. 50 cts.; 2 lbs. 85 cts.; 8 lbs. $\$ 3.25 ; 16$ lbs. $\$ 6.00$.

WIISON'S BOUNTIFUI GREEN POD. LONg, fleshy, flat, broad pods, tender and brittle and absolutely stringless; very early and productive.

FUII MEASURE. A fine main crop variety; stringless, round, green pods; very productive,

CING OF THE EARIIES, (Black Valentine).

Round pods; very early and a heavy yielder. Hardy and can be planted earlier than others.

STRINGIESS GREEN POD. Long, round pods; early; stringless at all stages. A heavy yielder.

Valentine, Extra Early Red. Round pods.

Refugee, Extra Farly. Round, light green pods.

Refugee Iate, or 1,000-to-1. For pickling.

Dwarf Fortlcultural. Snap or Shell. Flat Dods.

English Broad windsor. Very hardy; height about s feet. Sow as early as the ground can be worked in order to get into pod before heat sets in.

\section{PRICES OF WIISON'S BEANS}

All 20 cts. $1 / 2$ lb. 35 cts. lb.; 70 cts. 2 lbs. $\$ 2.658$ lbs.; $\$ 4.7516$ lbs. - except Masterpiece.
Beans, sometimes referred to as "Vegetable Beefsteak," being high in proteln content are the most nutritious of all vegetables. They are muscle builders and sustain men under the strain of steady work. They also fertilize the soll PIANT PIENTY.

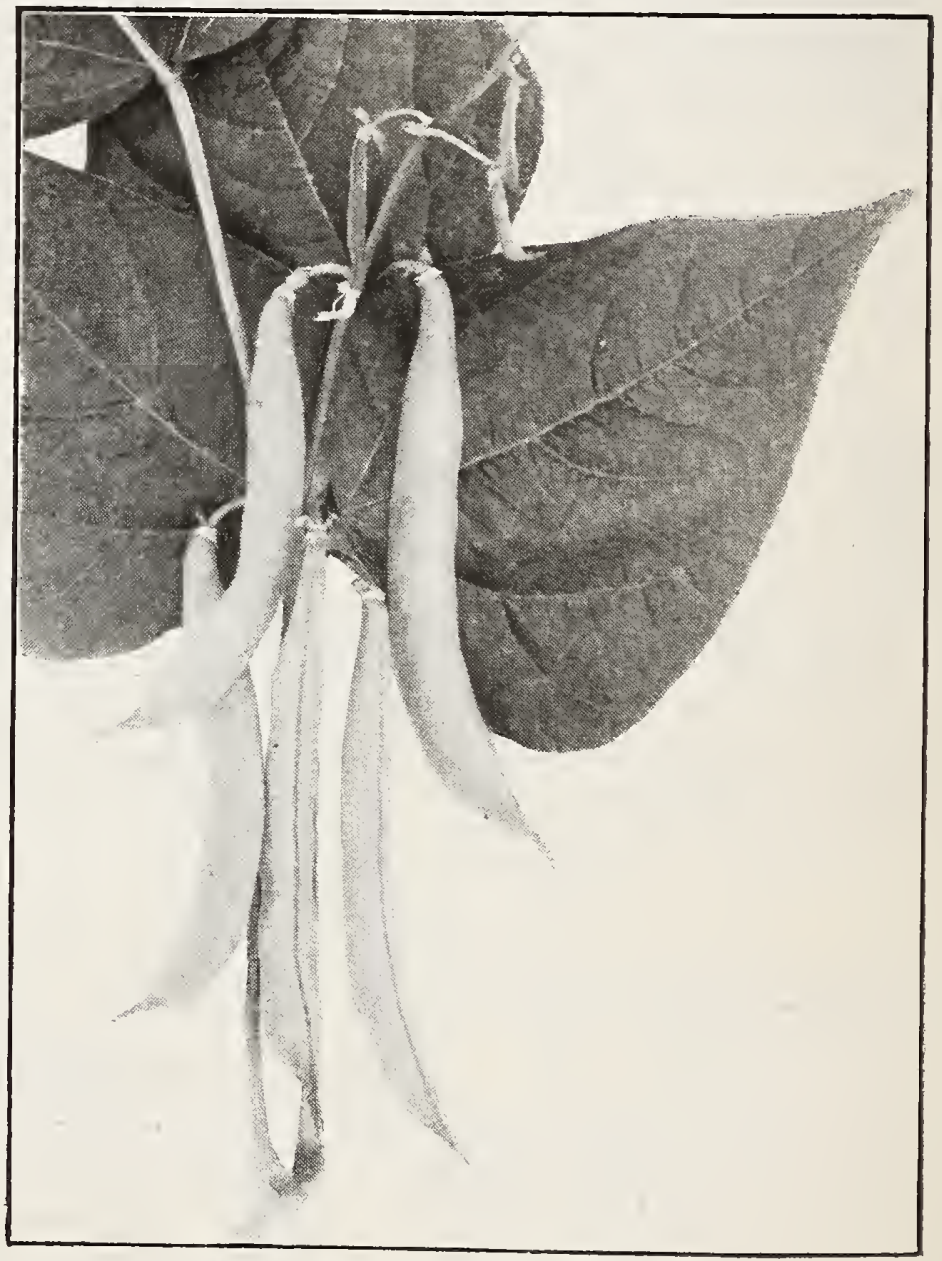

Wilson's Masterplece Beans. 


\section{WILSON'S BEANS-Continued}

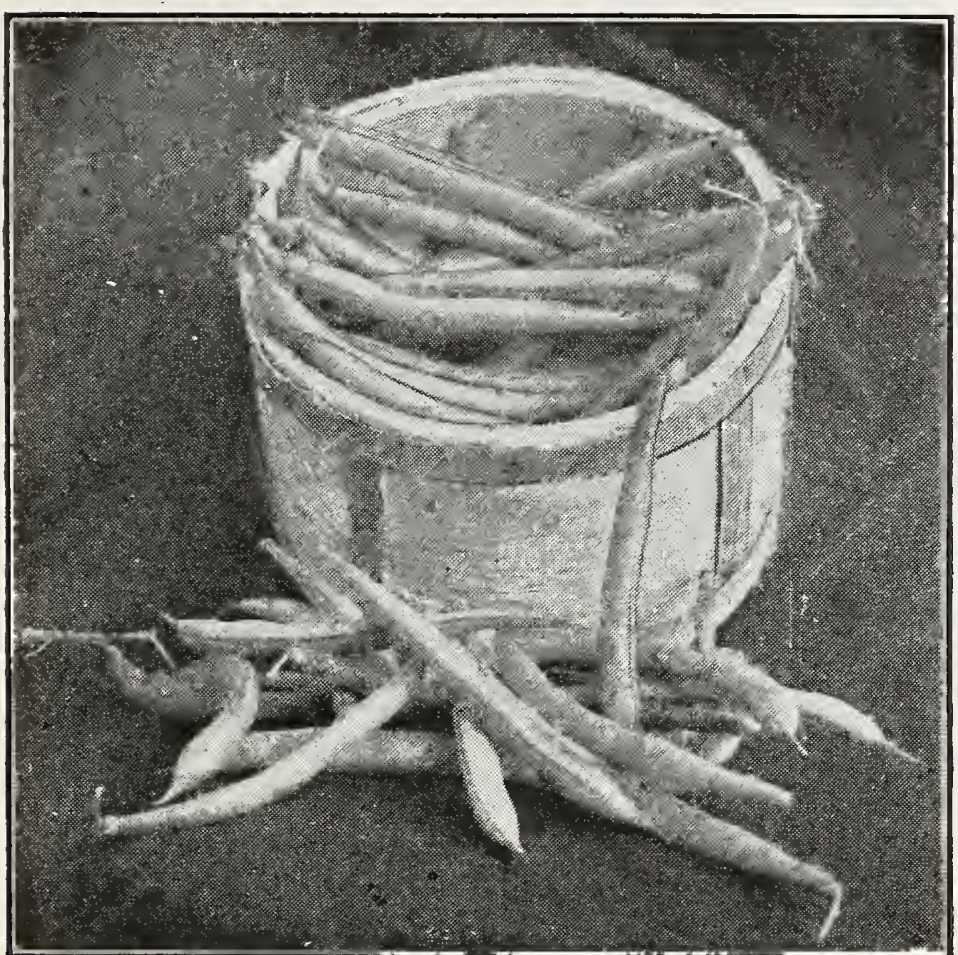

Wilson's Improved Golden Wax Beans.

\section{DWARF or BUSH WAX BEANS}

Iiberal pkt. $10 \mathrm{cts}$; $1 / 2$ 1b. $20 \mathrm{cts}$; 1b. $40 \mathrm{cts}$.; 2 lbs. 75 cts.; 8 lbs. $\$ 2.75$; 16 lbs. $\$ 5.00$.

WILSON'S IMIPROVED GOIDEN WAX. LONg, flat, meaty, golden yellow pods. Early and very productive.

Wardwell Kidney Wax. Long, almost straight, flat pods. Very prolific. A trifle later than Improved Golden Wax.

WIISON'S SURE CROP STRINGIESS WAX (also called California Rust-Proof.) Stringless at all stages; black-seeded; pods of good size thick and flat and of excellent quality. Very early.

\section{POLE (CLIMBING) STRING OR SHELL BEANS}

Iiberal pkt. 15 cts.; $1 / 2$ 1b. 25 cts.; 1b. 45 cts.; 2 lbs. 80 cts.; 8 lbs. $\$ 3.00$; 16 lbs. $\$ 5.75$.

After settled warm weather, set poles 6 to 8 fest long in rows 4 feet apart and extending north and south, the poles being 3 feet apart in the row. Let the poles slant slightly toward the north. Around each pole plant five to eight Beans $1 \frac{1}{2}$ to 2 inches deep. When well started thin to four plants. OID HOMFSTFAD OR KENTUCKY WONDER. Round pods 7 to 9 inches long; stringless. scarlet Runner. Largely grown for ornamental purposes.

\section{The Very Best Dwarf, or Bush Lima Beans}

2 lbs. will sow a row about 100 feet long; 45 1bs. to the acre. Plant seed eyes down. Mature in 60 to 80 days, two weeks earlier than Pole Iimas.

Iiberal packets $15 \mathrm{cts}$, each.

CULTURE-As soon as danger of frost is over and the soll has become warm, sow Beans in rich, light loam in rows 2 feet apart, 3 to 4 inches apart in the rows, and cover them to a depth of $1 \frac{1 / 2}{2}$ inches. Hoe often. A top dressing of good fertilizer or compost will hasten maturity and increase yield.

FORDHOOK BUSH. (Scarce.) The best bush Lima. Immense pods; enormously productive; quality unsurpassed. Lb. 50 cts.; 2 lbs. 90 cts.; 4 lbs. $\$ 1.75$.

Bush Iima, Buxpee's. Good-sized pods; large thick Beans of excellent quality. Lb. 40 cts.; 2 lbs. $80 \mathrm{cts} ; 4 \mathrm{lbs}$. $\$ 1.50: 8 \mathrm{lbs}$. $\$ 3.00$.
Improved Bush Iima. Larger than the foregoing, heavier yielder, and earlier. Lb. $45 \mathrm{cts}$; 2 lbs. 85 cts.; 4 lbs. $\$ 1.65 ; 8$ lbs. $\$ 3.25$.

Bush Iima, Henderson's. Very productive; early. Lb. 45 cts.; 2 lbs. 85 cts.; 4 lbs. $\$ 1.60$.

\section{Quality is remembered long after price in} forgotten.

NOTE.-All prices include cost of transportation except where otherwise noted.

\section{Wilson's choice of the Pole Lima Beans}

I.iberal pkts. 10 cts.; 1/2 lb. 20 cts.; 1b. 40 cts.; 2 lbs. 75 cts.; 3 lbs. $\$ 2.75 ; 16$ lbs. \$5.25. 2 lbs. will plant about 150 hills. Mrature in 90 days.

CULTURE-Pole Beans, especially Limas, are very sensitive to cold and wet, and if planted in cold or sogg $\$$ soil will rot. Set the poles 4 feet apart each way and, when danger of frost is past, and the ground has become warm, plant four or five Beans around each pole. When the young plants come up, thin to three to the pole; hoe and cultivate freely; and where possible top dress each hill with a small quantity of manure, compost or other good fertilizer. See also Cultural Notes on Pole String Beans, this page.

EARIY IEVIATHAN. Earliest of all; enormous pods and Beans; great yielder.

CARPINTIRIA. Early; splendid flavor; very vigorous grower and great yielder.

CHAIIFNGFR (Potato Iima). Very productive: thick pods and beans.

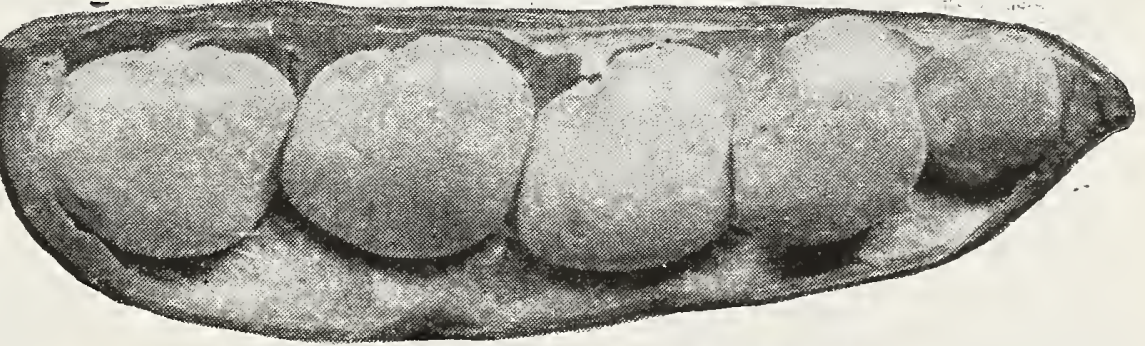

Early Ieviathan Pole Lima Beans.

KING OF THE GARDrN. Large pods averaging 5 to 6 inches long, in great profusion; large Beans. GIANT PODDFD. Vigorous grower; large pods, often 7 inches long and $1 \frac{1}{2}$ inches broad. Beans extra large and thick and of fine flavor.

\section{Tender BRUSSELS}

One ounce will produce about 3,000 plants. Mature in about 150 days.

CULTURE-Sow seed in frames or open ground, and transplant same as cabbage. Have rows 3 feet

apart and plants $1 \frac{1}{2}$ to 2 feet apart in the rows. Cultivate like Cabbage. For late use sow in June.

WIISON'S CHAMrION. Very tender; prolific Pkt. 10 cts.; oz. 30 cts.; 1/4 1b. $\$ 1.00$; ib. $\$ 3.50$.

We carry a complete line of Sherwin Williams paints -best in the world. "Household Painting Guide"it stops mistakes in painting-free for the asking. 


\section{Tender and Sweet GARDEN BEETS Not the Woody Kind}

One ounce will sow a row 50 feet 10ng; 6 to 7 pounds to the acre. Beady for table in 40 days after sowing.

CULTURE-Sow in spring, when the apple is in bloom about 1 inch deep in rows 1 foot apart. When the plants have made three or four leaves, thin out to stand 4 to 6 inches apart in the rows. Cultivate thoroughly. For succession, sow at intervals of about two weeks until August 10th. Fibrous loam, well enriched and drained, will produce good Beet crops.

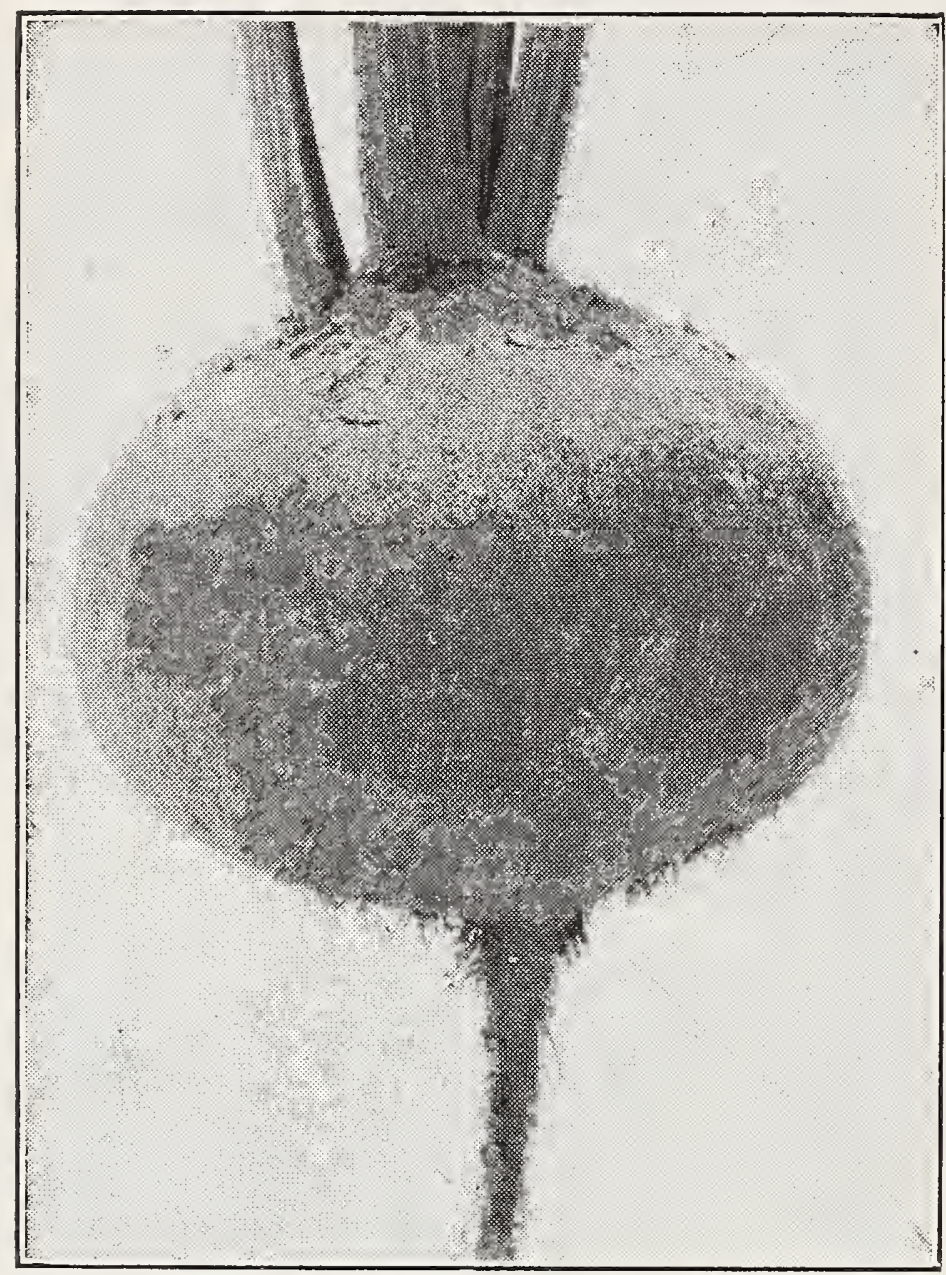

WIlson's Detroit Dark Red Beot.

WIISOI'S SEIECTED DFTROIT DARK IFD. Globular; deep vermilion flesh, zoned lighter; very sweet and tender. For early or late sowing; our seed produces the darkest colored beets showing seed produces the darkest colored beets showing Pkt. $10 \mathrm{cts}$. : oz $20 \mathrm{cts}$.; $1 / 4$ lb. $60 \mathrm{cts}$.; $1 \mathrm{~b} . \$ 2.00$. Pkt. 10 cts.; OZ. 20 cts. ; $1 / 4$ 1b. 60 cts.; $10 . \$ 2.00$. most uniform sort we have ever seen. It is almost round, deep ox-blood color, small, clean tap-root and medium top. Wonderfully tender and sweet. Pkt. 10 cts.; oz, 20 cts.; 1/4 lb. 60 cts.; lb. $\$ 2.00$.

WIISON'S CROSBY'S FGYPTIAN. Selected Seed. Deep red flesh, slightly zoned; very smooth, tender Deep red flesh, slightly zoned; very smooth,

Pkt. 10 cts.; oz. 20 cts.; $1 / 4$ lb. 50 cts.; 1b. $\$ 1.75$ WIISON's CRIMson GIOBz. Selected seed. A second-early globe-shaped Beet of medium size. The flesh is rich, blood-red, very sweet and free from stringiness.

Pkt. 10 cts.; oz. 20 cts.; 1/4 1b. 60 cts.; 1b. $\$ 2.00$.

Feed Your Cows and Chickens

MANGEL-WURZEL and SUGAR BEET Oz. 10 cts.; 1/4 1b. 35 cts.; 1b. \$1.25.

Two ounces to 100 feet of row; 6 pounds to the acre. Mature in 80 to 120 days.

Sow in May or June in rows 2 feet apart and thin to 9 inches in the row. Cultivate well.

MAMOMOTE IONG RED. Very large; flesh white, tinged with rose

Golden Tankard. Large, ovoid roots; yellow flesh zoned white; fine

ciant Bed sckondorfer. Large cylindrical roots. Immense yielder

clein Wanzleben Sugar Beet. Snow-white flesh heavy vielder.

FOR A PFRF'PC IAWN-Wilson's Jvergreen Iawn Seed. See page 3. Bxplicit instructions on how to make a lawn on inside front cover.

\section{BIRD SEED—see page 18. \\ SWISS CHARD}

The poor man's friend Or CUT-AND-COME-AGAIN SPINACB

CULTURE-Sow early in spring, in rows 16 inches apart, and thin out to 6 inches apart in the rows. ounce of seed is sufficient for a medium-sized family. As it grows, thin out for use and keep clear of weeds. Good cultivation increases the tenderness of the leaves.

GREFIN CURIPD. Pkt. 5 cts.; oz. 15 cts.; 1/4 lb. 45 cts.; $1 \mathrm{~b} . \$ 1.50$.

IUCUIIUS. Larger than above; dark green crinkled leaves, heavily ribbed. Pkt. 5 cts.; oz. 20 cts. $1 / 4$ 1b. 60 cts.; 1b. $\$ 2.00$

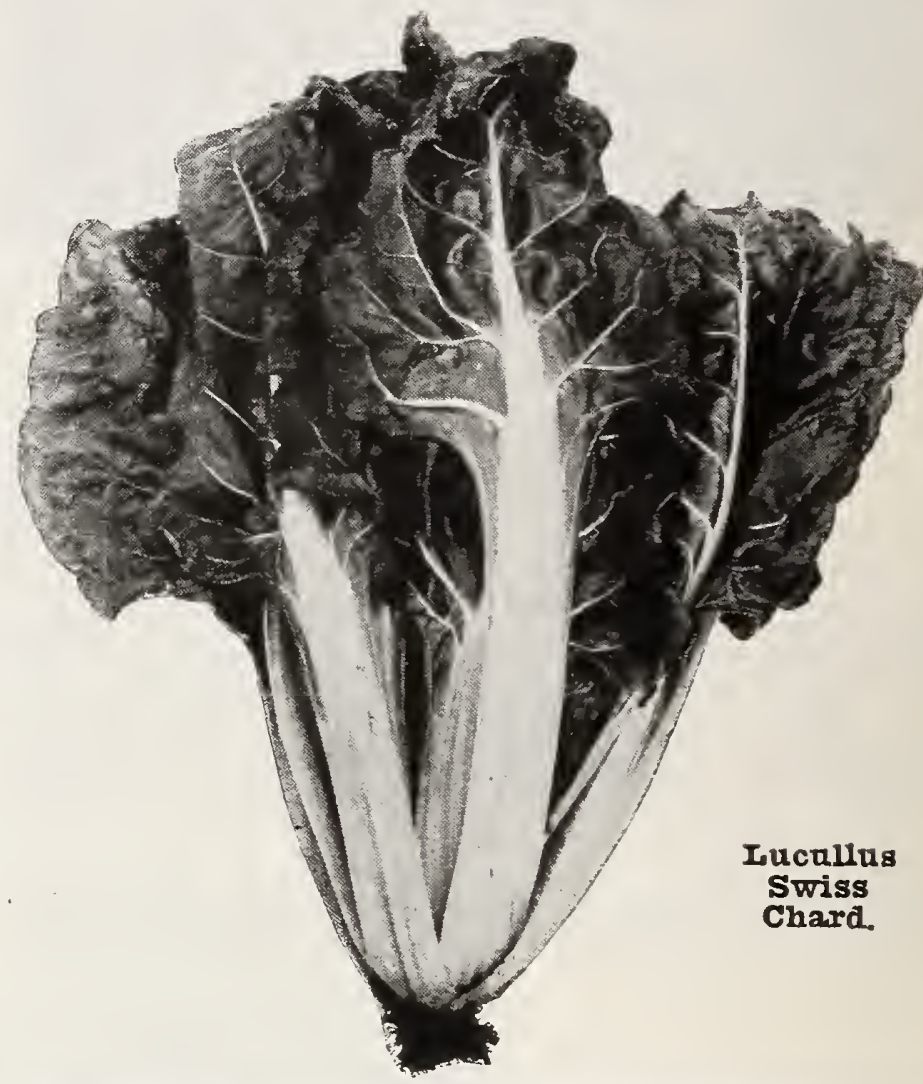

Fertilize plentifully; it doesn't pay to sow good seeds in poor soil Use WIISON'S Fighgrado Complete Garden Fertilizer as listed on page 4

\section{BROCCOLI}

The Sure-Heading Kind

One ounce will produce about 3,000 plants. Mature in about 150 days.

Cultivate same as Cauliflower. Much like Cauliflower, but coarser and harder.

FARIX WFITE CAPE. Creamy white; sure header Pkt. 10 cts.; oz. 50 cts.; $1 / 4$ lb. $\$ 1.50$; 1b. $\$ 5.00$.

\section{VEGETABLES IN SHADE}

Shaded portions of the garden may be used during the hot season for the production of vege tables. Prepare the bed early, manuring well and forking it under, fining the soil as thorough Iy as possible.

Cabbage and Cauliflower will do well in good soil in a situation of this kind, in an average or usual season.

Peas for use from July on to the close of the season may be grown in just such a sltuation Dwarf Beans are another vegetable that mar be produced in partial shade.

Spinach along a shaded border wll remain in cood condition for a considerable season, and turnips for use during July and August can be produced in the shady garden. 


\section{Early and late CABBAGE of great food value}

All $10 \mathrm{cts}$. per liberal packet.

One ounce will produce about 2,000 plants; 4 ounces will produce enough plants for one acre. IMatures in 65 to 120 days.

CULTURE-For early crop sow in hotbeds in February or March $1 / 2$ inch deep and prick out into cold-frames to harden. When danger of frost is over set out plants in the open in rows $21 / 2$ feet apart and 2 feet apart in the row. For second early crop sow in April and for late crop in June. Sow Chinese Cabbage in Augustnot before. This is important.

WIISON'S NEW EARIY GIANT SOIID HrAD. This variety niatures between the Copenhagen Market and the Glory of Enkhuizen. It is round, larger than Copenhagen and does not crack as easily. It has done splendidly under dry weather conditions, developing perfect heads. We recommend it for both early and late. The heads are very solid and will keep well. Oz. $50 \mathrm{cts}$; $1 / 4$ lb. $\$ 1.75 ;$ lb. $\$ 6.00$.

EARIY JERSEY WAKEFIEID. A very early, sure-heading Cabbage, largely grown by home gardeners. Forms nice, medium sized, pointed heads, solid and of good quality. 1/2 oz $25 \mathrm{cts}$; ; oz. $40 \mathrm{cts}$. $1 / 4$ lb. $\$ 1.25 ; 1 \mathrm{~b} . \$ 4.00$.

PREMIUM IATE FIAT DUTCH. Forms

large, flat heads, uniform, solid and of

finest quality: grown especially for winter use.

finest quality; grown especially for winter use.

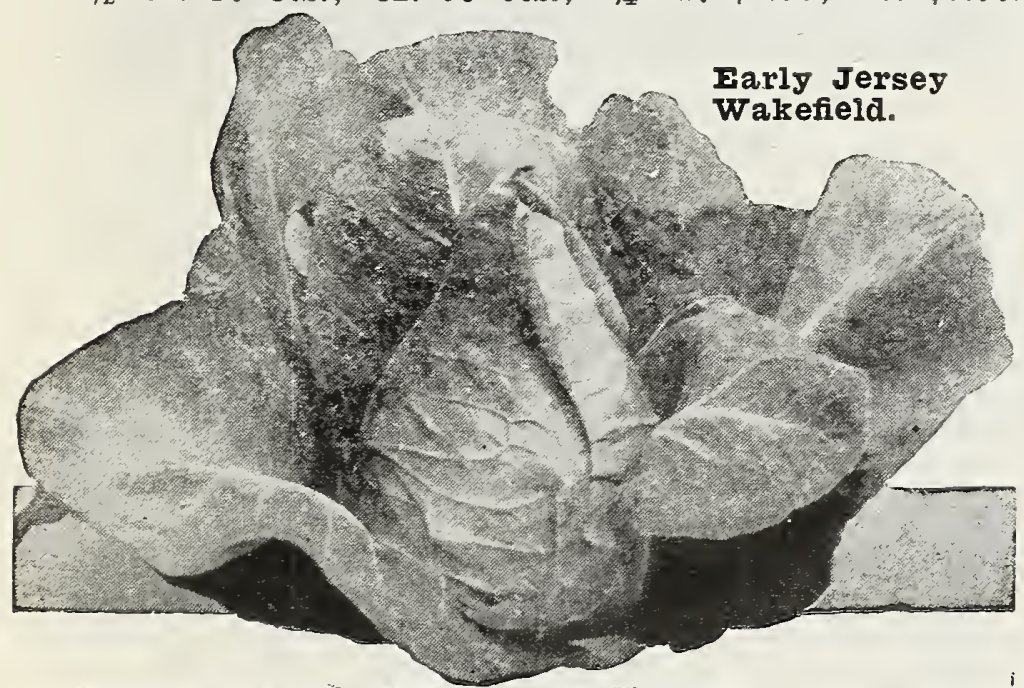

DANISH BAITHEAD, Or HOIIAND. A mediumsized round-headed sort, of good quality. One of the best for shipping and for winter keeping. $1 / 2$ oz. 25 cts.; oz. 40 cts.; $1 / 4$ lb. $\$ 1.25 ;$ lb. $\$ 4.00$.

AMERICAN DRUMHEAD SAVOY. The best of all Savoys for the home garden: grows strong and vigorous with dense, crumpled leaves and solid vigorous with dense, crumpled leaves and solid
heads. $1 / 2$ oz. 20 cts.; oz. $3^{\prime}$ cts.; 1/4 lb. $\$ 1.00$; 1b. $\$ 3.00$.

MAIMMOTH RED ROCK. Fine for pickling. Round, solid heads, dark red. 1/2 oz. 25 cts.; oz. 40 cts. $1 / 4$ lb. $\$ 1.25$; 1 . $\$ 4.00$.

Copenhagen IMarket. Large, round, solid heads. Exceedingly early. $1 / 2 \mathrm{oz}, 25 \mathrm{cts}$; $0 z .40 \mathrm{cts}$; $1 / \mathrm{k} \mathrm{lb}$. $\$ 1.25 ; 1 \mathrm{~b}$. $\$ 4.00$.

\section{CHINESE CABBAGE (Wong Bok)} Also Called CrIFRY CABBAGE Be sure to grow some.

A wonderful salad plant growing 15 or 16 inches high, resembling cos lettuce. It yields an unusual amount of most excellent salad. Cut up like cabbage and served with mayonnaise or French dressing, it makes a splendid cole-slaw. Can be boiled like cabbage and served with cream sauce, but is without the strong flavor and odor of cabbage. The hearts blanch to a crystalline white: every leaf, including the outside ones, is delicate and tender. Sow in August and thin plants to stand 18 inches

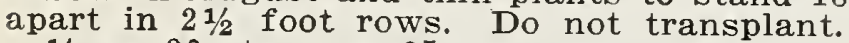

$1 / 2$ oz. 20 cts.; oz. 35 cts.; $1 / 4$ lb. $\$ 1.25 ;$ lb. $\$ 4.50$.

Add a small piece of charcoal to the water in which cabbage is cooking. This prevents any odor.


Oz. 15 cts.; 1/4 lb. 50 cts.; lb. $\$ 1.75$.

Scarlet Horn, or Short Forn. Early, medium sized, half long sort of fine color and flavor. Very tender. Oz. 20 cts.; 1/4 lb. 60 cts.; lb. $\$ 2.00$.

Improved Iong Orange Very productive and uniform in shape; fine for table or stock.

DON'T PORE FUN AT THE IOWTY CARROT Carrots are more easily digested than any other A lew vers thinly sliced Carrots and an Onlon or two glve additional savoriness to Iomato Boutuon.

Onlons and Carrots are good scalloped together with bread crumbs. 


\section{DELICIOUS CAULIFLOWERS}

SURE HEADING

One ounce will produce about 2,000 plants. Ready for table in 90 to 120 days.

CULTURE-Sow in hotbeds early in March; when plants are sufficiently large, transplant to coldframes and oradually harden by exposure. Set out in the and graducer will permit, in rows 3 feet apart and 2 feet apart in rows. Give rows 3 feet apart and 2 feet apart in rows. Give 100-to-1 solution of Nitrate of Soda and again ten days or two weeks later. Cauliflower must be kept growing right along without check and must be watered copiousis.

WITSON'S IXTRA TARIY PFDIGRPE SNOW. BATI. This is undoubtedly the earliest of all ins of Snowball Cauliflower. Moreover it is thains of snow the dwarfest, the most compact in habit of growth clean snow white heads either outdoors or under glass, and due to its dwarf habit can be planted as close as 18 inches apart in rows. Pkt. 50 cts. $1 / 4$ oz. $\$ 1.25$; Oz. $\$ 4.00$

WIISON'S FXTRA FARIY SNOWBAII. V e ry early; sure header; medium to large; snow-white; deep and solid compact heads of finest quality. Pkt. 25 cts.; 1/4 oz. 85 cts.; oz. $\$ 3.00$.

Autumn Giant. Late variety forming large, white heads. Pkt. 10 cts.; oz, 60 cts.; 1/4 1b. $\$ 2.25$

Celery will keep fresh for a week if you roll it up in wrapping paper, then in a towel, and store it in a dark place. Before using it, lay it in a basin of cold water for an hour.

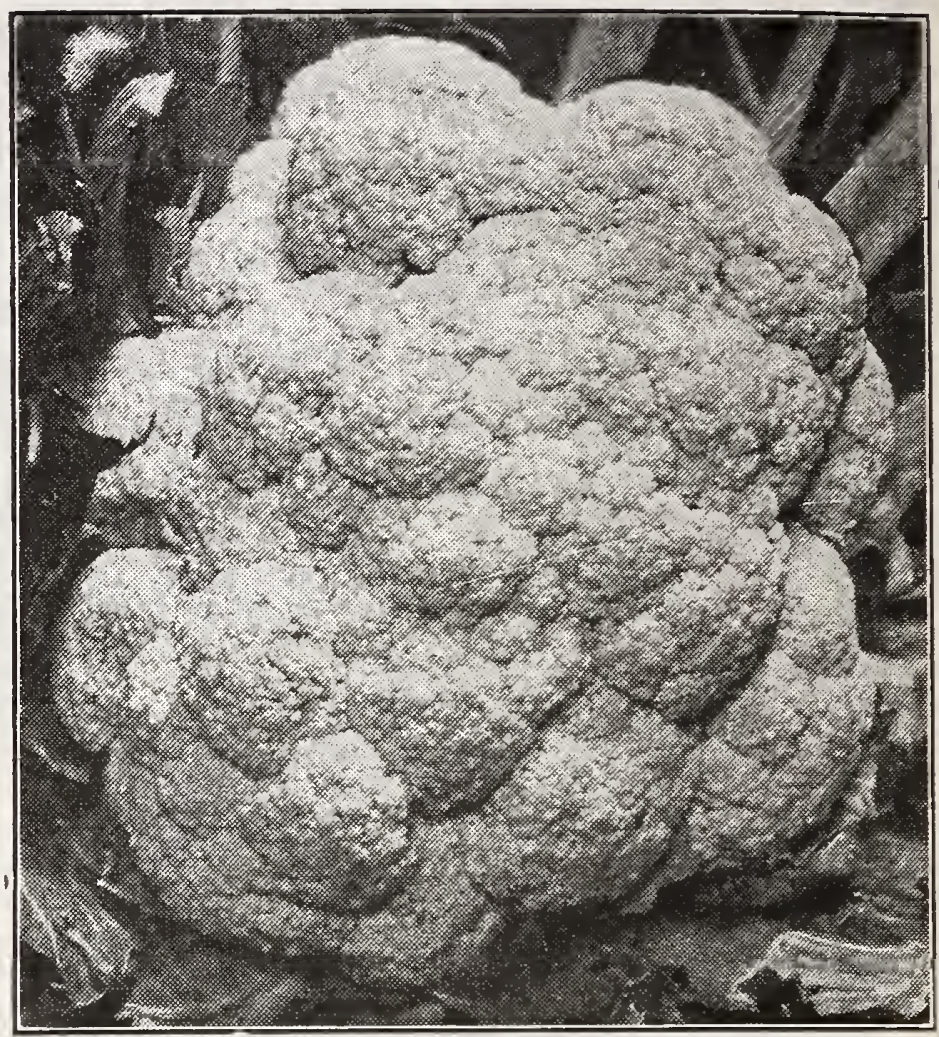

Wilson's Fxtra Farly Pedigree Snowball Cauliflower-Best of All.

\section{Early CRISP AND NUTTY CELERY Late}

Matures in 110 to 150 days. One ounce will produce about 3,000 plants.

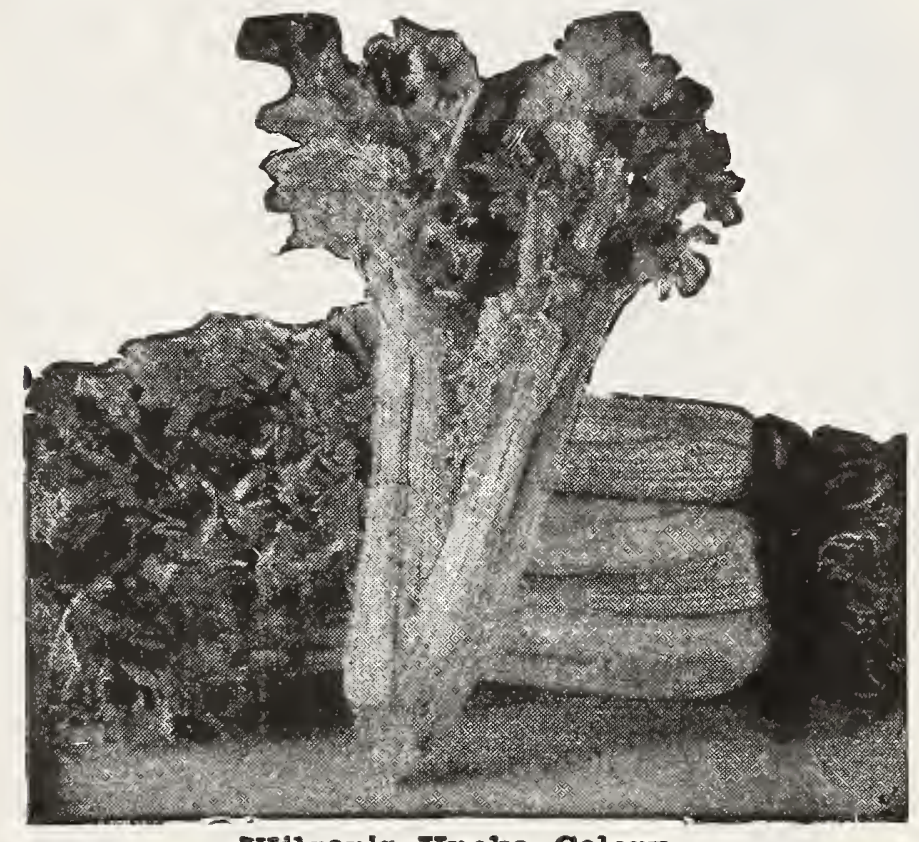

Wilson'z Uneka Celery.

CULTURE-Sow as early in the spring as the ground can be worked, in well prepared soil. Sow seed in rows, covering about four times its size and firming well into the soil with a board. See that the firming well into the soil with a board. See that the set the plants out in rows 3 to 4 feet apart, and 6 set the plants out in rows 3 to 4 feet apart, and
inches apart in the rows. Draw the earth up to them as they grow, but be careful not to allow any to get into the hearts. Spray with Bordeaux Mixture for blight.

WIISON'S UNIKA. Best of all. Very vigorous and hardy. Heavy, thick stalks of medium height and of a yellowish tinge: easily: blanched; almost as early as Golden Self-Blanching but superior in every way. Pkt. 10 cts.; oz. 75 cts.; 1/4 1b. $\$ 2.75$.

WHITP PUUMI IMPROVID. Early; a vigorous grower. Stalks large and uniformly white; requires only a short time to blanch. Pkt. 10 cts. oz. 35 cts.; $1 / 4$ lb. $\$ 1.25$.
GIANT PASCAI. A large, green Celery with golden yellow heart; very easily blanched. The stalks are thick, solid and crisp. and of a rich, nutty flavor. It is an excellent keeper. Pkt. 10 cts.; oz. 30 cts. $1 / 4$ 1b. $\$ 1.00$; 1b. $\$ 3.50$.

PASY BIANCHING. A vigorous grower of medium helght with thick stalks of excellent quality. A desirable sort for the amateur because it blanches easily and is a splendid keeper. Pkt. 10 cts. oz. 40 cts.; $1 / 4$ lb. $\$ 1.25 ; 1 b . \$ 4.50$.

\section{Other valuable crisp CELERIES}

Golden Self-Blanching. Early; solid golden yellow crisp and tender. Pkt. $10 \mathrm{cts}$; oz. $60 \mathrm{cts}$; 1/4 lb. $\$ 2.25$; 1b. $\$ 8.00$.

winter Queen. Medium-dwarf, forms a good solld heart and blanches creamy white; late keeper. Pkt. 10 cts.; oz. 25 cts.; 1/4 1b. 75 cts.; lb. $\$ 2.50$.

Soup or Cutting Celery. Grown for the tops only. Pkt. 5 cts.; oz. 15 cts.; 1/4 1b. 50 cts.; 1b. $\$ 1.50$.

Celeriac, Irarge Smooth Prague (Turnip-Rooted or Knob Celery). Produces large, globular roots used for soups and stews. Pkt 10 cts. oz. 30 cts. $1 / 4$ 1b. $\$ 1.00$; 1b. $\$ 3.50$.

For a Perfect Iawn
Sow wIIsON's "IVIRGRJIN" IAWI SHED.
How to make a lawn-See inside front cover.

\section{TPSTIMTONY!}

Not Only Good Seeds, But Good Service My garden has been lovely this year. I feel I must thank you. Especially for the glorious Nasturtiums and Cosmos and for your very kindly help over the phone when I have asked for information.

Sept. 8, 1925
MRS. G. B., J. 


\section{WILSON'S SWEET CORN}

\section{REAL SUGAR CORN}

We supply liberal packets of Corn at 10 cts. postpaid. 2 lbs. will plant about 200 hills; 12 lbs. to acre. Ready for the table in 60 to 90 dajs.

CULTURE-As soon as the weather is settled and the soil warm, plant about 2 inches deep in hills 3 to 4 feet apart each way, about six seeds to the hill in well drained soil. When the plants come up thin out and allow the strongest three to reup, thin out and allow the strongest three to remain. Hoe often, for constant cultivation is the about every ten days to the end of July.

GOIDFN FVPRGRFrN, WIIsON'S. Very sweet and tender. Ears much larger than Golden Bantam and are usually produced two to the stalk. It matures only a few days later than Golden Bantam. 1/2 1b. 29 cts.; 1b. 30 cts.; 2 lbs. 60 cts.; 8 lbs. $\$ 2.25$.

zOWIING MOB. Second-early. Large ears; tender and very sweet. Splendid for late planting. Can and very sweet. Splendid for late $1 / 2$ lb. 15 cts.; be sown as late as July 15 th. $1 / 21$. 1 .

growrIS'S FVIRGREFN. A standard main-crop sort; very productive, tender $\begin{aligned} & \text { and } \\ & \text { sweet. }\end{aligned}$ 8 lbs. $\$ 1.85$.

\section{Other Good Real SUGAR CORNS}

1/2 1b. 15 cts.; lb. 30 cts.; 2 lbs. 60 cts.; 8 lbs. $\$ 2.25$. rayflower, wilson's Extra Early. Very early. Large ears of finest quality. 4 feet.

Golden Bantarn, Wilson's selected. Grows $4 \mathrm{ft}$. high; golden ears with deep kernels of delicious flavor. Very early.

Iong Island Beauty. Large ears, with milky white kernels; very tender. Medium early.

Metropolitan. Large, handsome ears of fine quality: very early.

Country Gentleman. Small ears; late.

Black Mexican.

\section{Slicing CUCUMBERS Pickling}

All $10 \mathrm{cts}$. per liberal packet except Telegraph.

One ounce will plant about 50 hills; 4 pounds to acre. Matures in 50 to 80 days.

CULTURE-Sow in May in hills 4 feet apart each way, putting in ten seeds to the hill and covering about 1 inch deep. When the plants attain their fourth leaf, thin out and leave the strongest growIng four. For a succession continue planting at intervals up to July.

WIISON'S EVERGREEN WHITE SPINE. Beautiful bottle green fruits, 8 to 9 inches long: flesh almost white, solid and luscious. Best for slicing. Oz. 25 cts.; $1 / 4$ lb. 85 cts.; lb. $\$ 3.00$.

WIISON'S IONG GREEN IMPROVED. Dark green fruits 10 to 12 inches long; firm, crisp and tender. Fine for pickles or for slicing. Oz. 25 cts.; $1 / 4 \mathrm{lb}$ 85 cts.; 1b. $\$ 3.00$.

DAVIS PERFECT. Very prolific and early. Fruits long and slim, often 10 inches in length. Oz. 25 cts.: $1 / 4$ lb. 85 cts.; lb. $\$ 3.00$

\section{Other Good Cucumbers}

Japan Climbing. Can be grown on trellis; for slicing or pickling. Oz. $25 \mathrm{cts}$; $1 / 4$ lb. $75 \mathrm{cts}$.

Green Prolific Pickling (Boston Pickling). Extra early. Oz. 20 cts.; 1/4 lb. 75 cts.; lb. $\$ 2.50$.

west Indian Gherkin. Small; used for pickles. Oz. 30 cts.; $1 / 4$ lb. $\$ 1.00$.

TEIEGRAPH FRAMI CUCUMBER. (English grown seed.) For forcing and for frames. Very large; extra fine. Pkt. 25 cts.

Vegetables should be cooked only long enough to make them tender. They are most nutritious when baked or steamed.

\section{CHICORY For Salads}

One ounce will sow 100 feet of drill.

CULTURE-Sow early in spring, in rows about 2 feet apart, in light rich soil. When the plants are large enough thin out to 6 inches apart in the rows: cultivate often.

WITLOOF, or FRENCH ENDIVE. Leaves usually eaten raw as a salad; can also be cooked like endive. Pkt. $10 \mathrm{cts}$. $0 z .40 \mathrm{cts}$; 1/4 1b. $\$ 1.25$; 1b. $\$ 4$. Magdeburg, Iong-Rooted. Pkt. 10 cts.; oz. 25 cts.; $1 / 4$ lb. 75 cts.; lb. $\$ 2.50$.

Grow witloof in your cellar in winter. We have fine big roots in November. Nothing easler to grow. Iet us book your order now. Price, 75 cts. per doz.; 25 for $\$ 1.30 ; 100$ for $\$ 5.00$

\section{Fall CORN SALAD Favorite (TITTICUS, ACRE SATAD)}

Three ounces will sow 100 feet of drill.

CULTURE-Sow in rows 1 foot apart in early spring and in August, September and October. If sown in October the plants require slight protection. Iarge Ieaved. Pkt. 10 cts.; oz. 25 cts.; 1/4 1b. 75 cts.; lb. $\$ 2.50$

\section{For a Perfect Iawn \\ WIISON'S EVERGREEN IAWN SEED. See page 3.}

How to make a lawn-See inside front cover.

\section{Appetizing CRESS (Pepper Grass)}

One ounce will sow a row about 50 feet lons. Matures in 20 to 30 days.

CULTURE-Sow in spring, as soon as the ground can be worked, in shallow drills about 1 foot apart, covering the seed lightly. When the young plants are well up, thin to 4 inches apart in the row. For succession sow every ten days.

Fine Curled. Tender, piquant leaves. Pkt. $10 \mathrm{cts.}$ oz. 20 cts.; $1 / 4$ lb. 60 cts.; lb. $\$ 2.00$.

water Cress. Distinct; thrives along moist banks and in wet soils. Pkt. $1.0 \mathrm{cts}$.; oz. $75 \mathrm{cts}$.

Neglect will make two weeds grow where only one grew before.

\section{COLLARDS, GEORGIA}

\section{Fine if you like cabbage}

A IOOSE-IFAF CABBAGE

Large, tender leaves; good flavor. It should be better known. Pkt. 5 cts.; oz. 20 cts.; 1/4 1b. 60 cts.; 1b. $\$ 2.00$

\section{CHERVIL For Garnishing}

Curled. Similar to Parsley; handsome for garnish ing. Pkt. 10 cts.; oz. 30 cts.; $1 / 4$ lb. $\$ 1.00$ ib. $\$ 3.00$.

Show me a well-ordered garden and I will show you a well-ordered home.

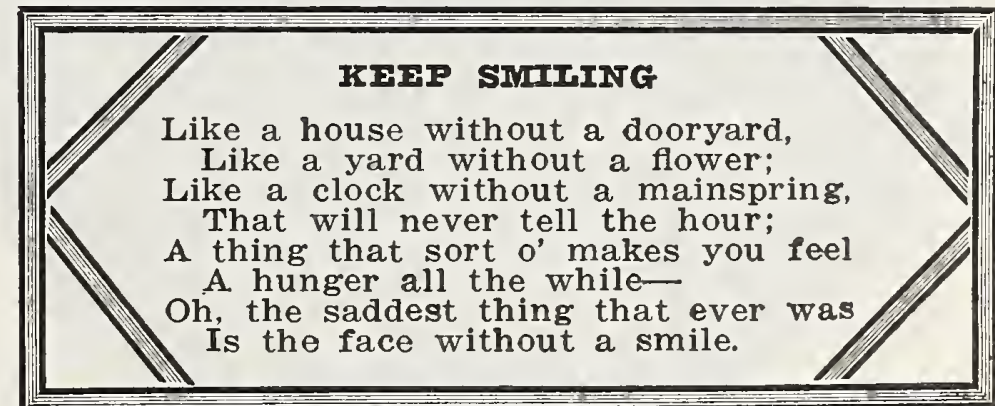

We carry a complete line of SHERWIN WIIIIAMS paints-best in the world. "Fousehold Painting Guide" free for the asking. 


\section{DANDELION Your Spring Tonic}

One ounce to 100 feet of row.

CULTURE-Sow in May in drills 1 foot apart, covering the seed $1 / 4$ inch deep. Rich soil is preferable, but this plant will thrive almost anywhere. COMLINON, or FRENCH. Pkt. $10 \mathrm{cts.;} \mathrm{oz.} 40$ cts.; $1 / 4$ lb. $\$ 1.25$.

THICK, or CABBAGE IEAVED. A very fine strain; almost double the size of the Common or French. Pkt. 10 cts.; oz. 70 cts.; 1/4 lb. $\$ 2.50$

\section{ENDIVE For Salads}

Pkt. 10 cts.; oz. 25 cts.; 1/4 1b. 75 cts.; 1b. $\$ 2.50$. One ounce to a 150 foot row; 3 lbs. to the acre.

Ready for the table in about 60 days.

CULTURE-For early use, sow in April; for late use in June or July. Sow in drills covering lightly. When plants are about 3 inches high thin to 1 foot apart in the rows; cultivate well, and when nearly full grown, and when plants are dry, begin to blanch by tying the leaves together.

IARGE GREEN CURIED. Hardy; deep green leaves easily blanched to rich creamy white.

Broad-Ieaved Batavian (Escarolle). Broad, flat, light green leaves; very easily blanched.

French Endive (Witloof). See Chickory, page 11.

\section{EGGPLANT THE TRUIT OF THEE}

Iiberal Pkt. $10 \mathrm{cts.;} 1 / 2$ oz. $30 \mathrm{cts.;}$ oz. $50 \mathrm{cts.;}$ $1 / 4$ 1b. $\$ 1.75 ; 1 b . \$ 6.00$.

One ounce will produce about 1,000 plants: 4,000 plants to the acre.

Ready for the table in about 140 days.

CULTURE-Sow seeds in hotbed or greenhouse early in March. Put young plants, as soon as they are ready to handle, into $21 / 2$ inch pots. In May or June take out of the pots and plant in. the open June take out of the pots and plant in the open
ground, in good rich garden soil, in rows 3 feet apart and 2 to 3 feet apart in the row. Hoe frequently and mulch during warm weather to preserve moisture.

Lots of folks kill eggplants by setting them in soil in which there is fresh manure. Stable manure should never be used on an eggplant. Give it a commercial fertilizer strong in potash. Wllson's Complete Garden Fertilizer-See inside front cover. NFW YORK PURPIE, or SPINEIESS, Early, vigorous and productive.

Black Beauty. Very early; large, purple black fruits.

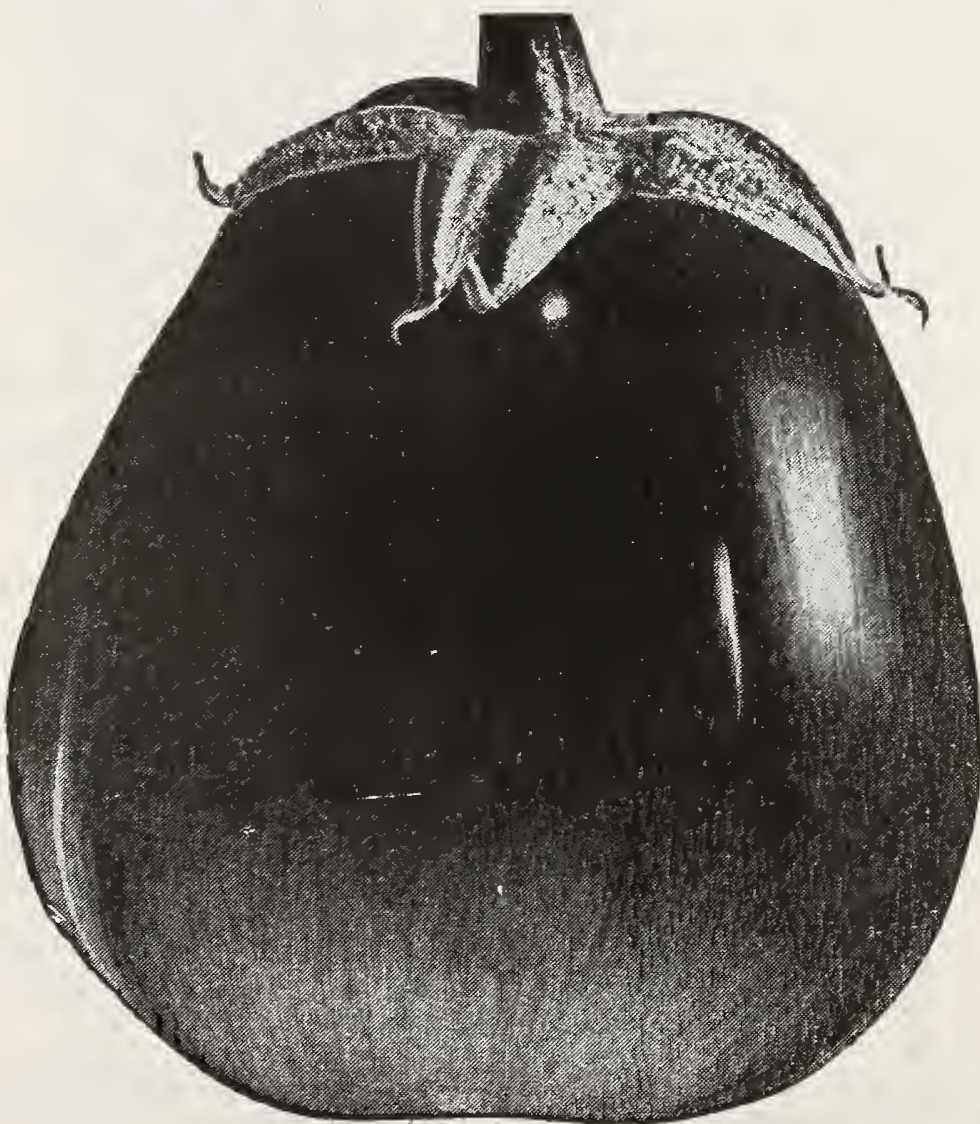

New York Purple Eggplant.

\section{HERBS see page 18.}

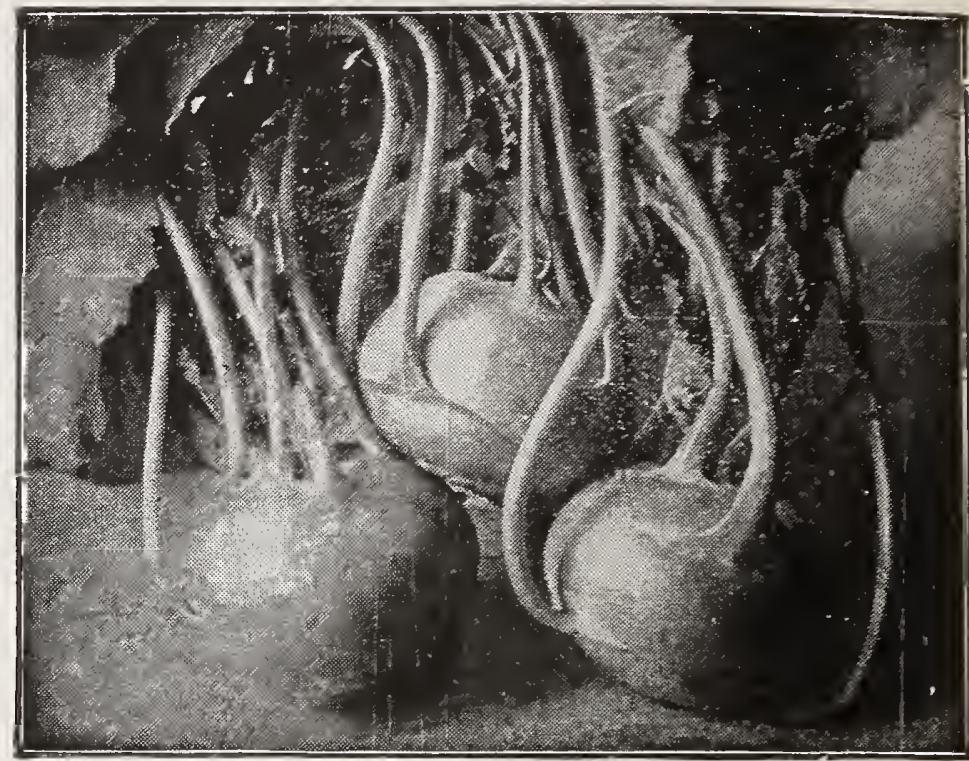

White Vienna Kohlrabi.

Tender KOHLRABI Fine Grain IIberal Pkt. 10 cts.; 0z. 35 cts.; 1/4 1b. $\$ 1.10$; lb. $\$ 4.00$. One ounce will sow a row 200 feet long. Ready in 60 days.

CULTURE-Prepare the ground as for cabbage. Sow early in May, and for succession up to July. in rows $11 / 2$ feet apart, thinning out the plants to 12 inches in the row. To preserve over winter treat as turnips.

BARIX WHITE VIENTA. Light: green, fine grained bulb: short leaves.

FARIY PURPII VIrINA. Same as above. except in color.

\section{KALE or BORECOLE}

\section{FROST-RFSISTING}

One ounce for about 5,000 plants; 4 pounds to acre. Ready for cutting in 50 days.

CULTURE-Sow in April or May, and for winter use in August or September, and cultivate the same as cabbage. Cover seed $1 / 2$ inch.

DWARF GREFN CURIJD SCOTCE. Large, finely curled leaves. Pkt. 10 cts.; oz. 25 cts.; $1 / 4$ lb. 75 cts.; 1b. $\$ 2.59$.

Siberian. "Sprouts" or "German Greens"" Leaves large cut and frilled, with bluish tinge. Pkt. 5 cts.; oz. 20 cts.; $1 / 4$ lb. 60 cts.; lb. $\$ 2.00$

Kale is a neglected regetable that comes in handy. It can be picked when the leaves are frozen stiff. Cultivate and spray it like cabbage.

\section{LEEK}

For Soups, etc.

One ounce will sow a row about 100 feet long; 4 lbs. to acre.

Ready for use in about 90 days from germination. CULTURE-Sow early in April and in midsummer, in rows 1 inch deep, 1 foot apart, and thin 4 to 6 inches in the rows; cultivate often. Draw earth up to them as they grow to insure white and tender Leeks.

WIISON'S PRIZE-WINNER. Large, long, thick white stems, often over 3 inches in diameter; very mild and sweet. A sure prize-winner. Pkt. 10 cts. oz. 30 cts.; $1 / 4$ lb. $\$ 1.00 ; \quad$ lb. $\$ 3.50$

American Flag. Very hardy and of good quality. Plit. 10 cts.; oz. 25 cts.; $1 / 4$ lb. 75 cts.; 1b. $\$ 2.75$. 
The Choicest, Crispest

\section{LETTUCES crop short.}

One ounce will produce about 2,500 plants;

3 ponnds to the acre. sow seed early in March about $1 / 2$ inch deep, in boxes or hotbeds. Transplant into fats or coldframes to harden off. As soon as the ground can be worked, set out in rows, 1 foot apart, allowing from 8 to 12 inches between the plants: cultivate frequently. For succession sow in the open ground every two weeks, from April to August. Soil well enriched with rotted manure is necessary, as lettuce must be grown without check. A 100 to 1 solution Nitrate of Soda, occasionally, works wonders.

40 to 60 days from seeding to maturity. All 10 cts. per liberal packet.

\section{CABBAGE OR HEADING SORTS}

FUSON'S AII-HEART. A splendid sort of ther for spring or summer sowing; withstands intense heat and forms immense hoads and extremely solid hearts. The color is a beautiful yellowish green, of color is a beautiful yellowish green, of the home garden. $1 / 2$ oz. 20 cts.; oz. 35 cts.; $1 / 1$ 1b. $\$ 1.00$.

WIISON'S SEIECTED BIG BOSTON. Large, tender heads; blanches beautifully. Fine for midsummer and fall planting and for forcing. $1 / 2 \mathrm{oz} .20 \mathrm{cts}$. oz. 35 cts.; $1 / 4$ lb. $\$ 1.00$; 1b. $\$ 3.50$.

FAXAzEAD. Early; sure header. Outer leaves light green, inner ones rich yellow; tender, crisp and buttery Splendid for coldframes or for the open ground. $1 / 2$ oz. 20 cts.; oz. $35 \mathrm{cts}$; $1 / 4 \mathrm{lb}$. $\$ 1.00$.

\section{OTHER GOOD HEAD LETTUCES}

All seasons. A vigorous sure header. Fine for summer. $1 / 2$ oz. 20 cts.; oz. 35 cts.; $1 / 4$ lb. $\$ 1.00$.

Iey Fing. Early; will stand much cold and damp; leaves yellowish green, tinged bronze, inside of head almost golden. $1 / 2$ oz. 20 cts.; oz. 35 cts.; $1 / 4$ lb. $\$ 1.00$.

Wow York, or Wonderful (Dark Iceberg). Very scarce. Immense heads; very solid; heart blanches beautifully; tender and crisp; fine for summer. $1 / 2$ oz. 20 cts.; oz. 40 cts.; $1 / 4$ lb. $\$ 1.35$.

\section{CURLED OR LOOSE-LEAVED LETTUCES}

All 10 cts. per liberal pkt.; 1/2 oz. 15 cts.; oz. 30 cts.; $1 / 4$ lb. $\$ 1.00$.

Eeat Resisting. Ready before heading varietles. GRAND RAPIDS, FORCING. Large, tender; fine. Early Curled Simpson. Large curled yellow-green leaves, crisp and tender.

BIACK-SEEDED SIMPSON. Best of the loose-leaf sort:. Tender; leaves ruffled; yellowish green.

\section{ROMAINE OR COS LETTUCE}

WEITE PARIS SEIF-FOIDING. Best of all Cos sorts. Long, spoon-shaped leaves, which if tied up will blanch nearly snow-white. Crisp and tender. Set the young pliants 6 inches apart in the rows. Set the young pliants 6 inches apart in th
$1 / 2$ oz. 15 cts. oz. 30 cts.; $1 / 4$ lb. $\$ 1.00$.

\section{WILSON'S CHICKEN LETTUCE} Oz. $25 \mathrm{cts}$; 1 1/4 1b. $75 \mathrm{cts}$; 1b. $\$ 2.50$.

For a fine velvety lawn sow WIISON'S EVERGREFI IAWN SEFD. See page 3.

How to make a lawn-See inside front cover.

Wilson Sells Seed of Nearly Every Blooming Thing.

\section{ANNOUNCEMTIT}

We carry a Complete Assortment of Sherwin willams paints, enamels, varnishes, etc. Color cards and S. W. "Household Painting Guide" (it stops mistakes in painting) free for the asking. We are $P A n T$ READQUARTERS. 


\section{Delicious, Aromatic, Spicy MUSKMELONS}

All 10 ots. per liberal packet. $1 / 2$ oz. 15 cts.; oz. 25 cts.; $1 / 4$ 1b. 75 cts.; 1b. $\$ 2.50$. One ounce will plant about 50 hills; 4 1bs. to acre. Ready for use in 60 to 90 days.

CULTURE-Early in May, when the ground is Colls 4 to 5 feet apart each way and sow 8 to 10 seeds in a hill, covering about 1 inch. When the fourth leaf appears, thin to 3 or 4 plants in a hill. Cultivate frequently. Spray

often with bordeaux or arsenate of lead.

WIISON'S FIIFAID GFII. Salmon-fleshed. Very (nich emerald-green skin with little netting. Luscious and spicy.

o S A G, or IIIIIFR'S CREAIM. Salmon-fleshed sized, vigorous grower. Fruits are highly flavored.

ROCKY FORD, or NFTIFD GEIM. Green-fleshed. small, oval melon of delicious flavor.

Eackensack Fxtra-Farly. Green-fleshed; large size; fine.

FONFY DEW. Light green flesh. Oval fruits of good size; splendid flavor. Ripens about midAugust.

\section{WATERMELONS}

\section{They Melt in Your Mouth}

Itberal Pkt. 5 cts.; oz. 20 cts.; 1/4 1b. 60 cts.; 1b. $\$ 2.00$.

One ounce will sow about 30 hills; 4 1bs. to the acre.

Ready for the table in 75 to 90 dajs.

CULTURE-Same as for muskmelons, except that the hills should be at least 8 feet apart.

Cole's Farly. Extra early; fine quality; red flesh.

Ice Cream, or Peerless. Round; scarlet flesh.

Monte Cristo, or Kleckley Sweets. Large; oval; flesh bright red, tender and sugary.

Tom Watson. A large, oblong melon; flesh red; delicious flavor.

Citron. Medium-sized, round; for preserves. Red seed.

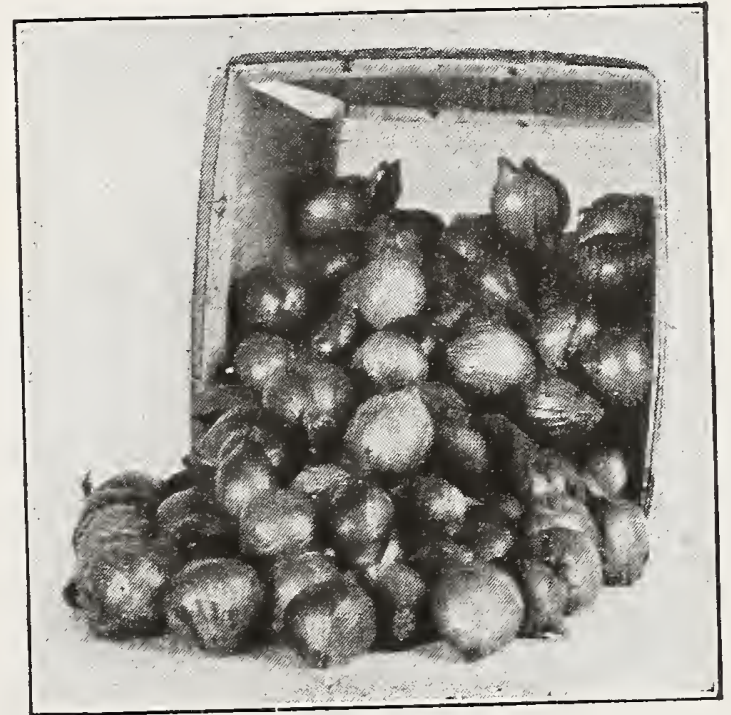

Onion Sets.

\section{SOLID ONION SETS}

Add 5 cts. per pint or 10 cts. per quart if wanted by mall. Prices subject to change as season advances. One quart to $75 \mathrm{ft}$ of row; 10 to 15 bus. to an acre.

CULTURE-Plant in drills 2 inches deep, 12 inches apart and 4 inches apart in the row.

White. Pt. 25 ct's.; qt. 50 cts.; 1/2 pk. $\$ 1.60 ;$ pk. $\$ 2.75$. Red. Pt. 20 cts.; qt. 40 cts.; $1 / 2$ pk. $\$ 1.40 ;$ pk. $\$ 2.50$ Yellow. Pt. 20 cts.; qt. 40 cts.; $1 / 2$ pk. $\$ 1.40 ;$ pk. $\$ 2.50$. APANFF (or Fbenezer). A large, somewhat flat yellow-skinned, white-fleshed onion of exceedingly yild are surprisingly firm with very indicating unusual lieeping qualities. will keep sound and hard all winter. Pint 25 cts. Will keep sound and hard all winter.

\section{Wilson's Choicest ONIONS very short}

All 10 cts. per liberal packet.

One ounce will sow a row about 150 feet long, 4 to $51 \mathrm{bs}$, to an acre.

CULTURE-Sow $1 / 2$ inch deep early in the spring. apart; when young plants come up, thin to 2 inches apart in the row. Hoe and cultivate often, but avola too deep cultivation and be careful not to draw the soil around the growing bulbs. For large Onions, sow seed in cold-frames in February and transplant to open ground when large enough. For early green or bunching onions, sow seed of Silverskin in August. and protect plants during winter.

For Onion Thrips use Wilson's O. K. Plant Spray. See page 4

PRIZETAKER. Yellowish brown skin; white flesh large size; heavy yielder. $1 / 2$ oz. 25 cts.; oz. 40 cts.; $1 / 4$ lb. $\$ 1.40 ; 1 b$. $\$ 5.00$.

AIISA CRAIG. Very large exhibition sort. Skin dark straw color; flesh pure white, mild and sweet. $1 / 2$ oz. 25 cts.; oz. 50 cts.; $1 / 4$ lb. $\$ 1.75 ; 1$ b. $\$ 6.00$. RED GIOBE SOUTHPORT. Fine, globe-shaped Onion; medium size; mild flavor: good keoper. $1 / 2$ Oz. 25 cts.; oz. 40 cts.; $1 / 4$ lb. $\$ 1.40 ; 1 b . \$ 5.00$ WHITE GIOBE SOUTHPORT. Clear white bulbs, of perfect globe shape. Fine-grained mild flesh of perfect globe shape. Fine-grained mild

YFILOW GIOBE SOUTHPORT. Same as the Red Globe, except in color of outer skin. 1/2 oz. $25 \mathrm{cts}$. oz. 40 cts.; 1/4 1b, $\$ 1.40 ; 1 b, \$ 5.00$.

SIIVFRSTIN or WHITy PORTUGAT. Used lärgely when young in salads and for pickles. $1 / 2 \mathrm{oz} .40 \mathrm{cts}$.; oz. 75 cts.; $1 / 4$ lb. $\$ 2.75$.

IARGF RED WFTHERSFIJID. Large, flat bulbs, pinkish white inside, purplish red outside. Bes for poor, dry soils. $1 / 2$ oz. 25 cts.; oz. 40 cts.;

YEIIOW GIOBE DANVERS. Main-crop; good size keeps well. $1 / 2 \cdot$ oz. 25 cts.; oz. 50 cts.; 1/4 1b. $\$ 1.75$ 1b. $\$ 6.00$.

Onions are highly prized for their tonic quall. ties, and consequently should be grown in every garden. One small onion eaten every night bofore retiring is a well-known doctor's presoription for numerous affections of the head and 18 highly recommended for sleeplessness; it acts on the nerves in a soothing way, without the on the nerves in a ontor, heated and placed in the ear, will often relleve the agony of earache, while the syrup procured from sprinkling a sliced onion with sugar and baking in the oven wlll work wonders in a "croupy" child.

Chop onions on a wet cloth and your eyes will not smart so badly.

WE AIWAYS TRY TO GIVF A IITTIF IMORE THAN FXPECTED, BOTH IN OUATITY OF GOODS AND IN EFFICIFNCY OF SERVICE

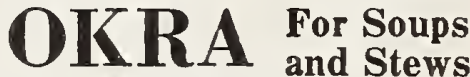

Pkt. 5 cts.; 2/2 oz. 10 cts.; oz. 15 cts.; 1/4 Ib. 40 cts.; 1b. $\$ 1.35$.

Four ounces to 100 feet of row; 20 lbs. to acre. sixty days from planting to maturity.

CULTURE-Sow seed as soon as ground is warm, in drills 3 feet apart and 1 inch deep. When the plants come up, thin to about $11 / 2$ feet apart in the drills. Requires rich, moist soil and frequent cultivation. Pods should be used only when young and tender.

WHITE VEIVET. Very productive; early.

Perkins' Mammoth Iong-Pod. Large, slender, deep green pods.

OYSTER PLANT see Salsify, page 17.

For a Perfect Tawn Sow WITSON'S a T PED. See page 3

How to make a lawn-See inside rront cover. 


\section{SEED POTATOES The Irish}

Standard Sorts at Market Prices.

For Scab, etc., use 1 pint Formalin to 30 gals. of water Soak from 30 minutes to $11 / 2$ hours according to amount of disease shown. Cut and plant wet.

\section{PARSTLY Essential in Every}

Plrt. 5 cts.; $1 / 2$ oz. 10 cts.; oz. 15 cts.; 1/4 lb. 45 cts.; 1b. $\$ 1.50$.

1 ounce will sow a row 100 feet long; 8 lbs. to acre. Ready for table about 70 days from time of sowing. CULTURE-Sow early in April in rows 1 foot apart and $1 / 2$ inch deep, and for a succession up to autumn. When the plants come up, thin to 4 to 6 inches apart in the row. Parsley seed is slow to germinate. and often in dry weather fails to come up; in this case water plentifully.

WIISON'S JERSFY GREFN. Handsome deep green finely curled moss-like leaves, Best of all.

Champion IMoss-Curled. Finely curled leaves. Hamburg, or Turnip-Rooted. Much esteemed for flavoring soups, stews, etc.

Plain or Italian. Very hardy; not curled.

Parsley is indispensable in sauces, soups, stews, and for garnishing. If slightly protected it will survive our northern winters.

\section{PARSNIPS Delicious Mashed Like Potatoes}

One ounce will sow a row about 100 feet lons;

8 lbs. to an acre. Mature in about 80 days.

CULTURE-Sow in the spring in good, deep soll as soon as the ground can be worked; make rows 18 inches apart and $1 / 2$ inch deep. When the plants are well up, thin out to stand about 6 inches apart in the rows. Parsnip seed usually comes up unevenly. Roll well after sowing.

WIISON'S HOIIOW CROWN PARSNIP. Large, heavy shouldered roots; white skin, tender, finegrained flesh. Pkt. 5 cts.; 1/2 oz. 10 cts. oz. 15 cts.; $1 / 4$ lb. 50 cts.; ib. $\$ 1.75$.

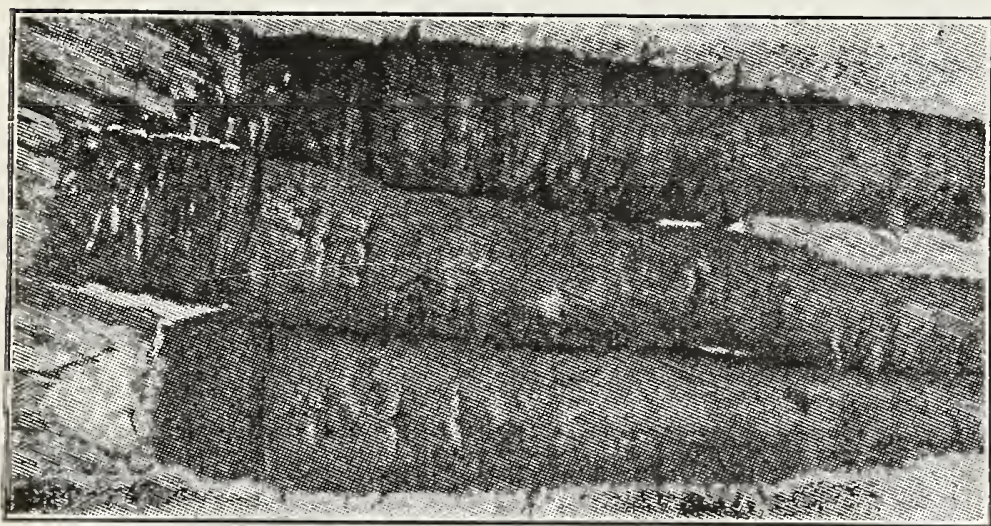

Oyster Plant. See Salsify, page 17.

\section{You'll Enjoy Wilson's Delicious PEAS}

\section{Crop vers short.}

2 lbs. will sow a row about 100 feet long; $11 / 2$ to 2 bushels to acre.

Ready for plcking in 42 to 70 days from germination. We supply liberal packets of Peas at 15 cts. each.

CULTURE-Peas require warm, light soil, well certilized. As soon as the ground can be worked, open rows 3 or 4 inches deep, 2 to 3 feet apart, into which drop the Peas and cover them. Cullivate same as beans. Smooth varieties are best for early planting. The wrinkled kinds are more tender, and should be sown later. Wilson's Pedigree and Ameer may be sown in August for latest crop.

WIISON'S PFDIGRFF FXTRA FARIY. Best of all earlies. Height $2 \frac{1}{2}$ feet. Ripens in about 44 days. Lb. 35 cts.; 2 lbs. 65 cts.; 8 lbs. $\$ 2.50$.

AMFFR (Claudit). Height 3 feet. An extra early Pea of excellent quality, following Gradus, which it excels as a cropper. Also called Mammoth Alaska. The peas ripen uniformly, the pods are long, dark green, sweet, tender and delicious. Lb. 40 cts.; 2 lbs. 75 cts.: 8 lbs. $\$ 2.75$.

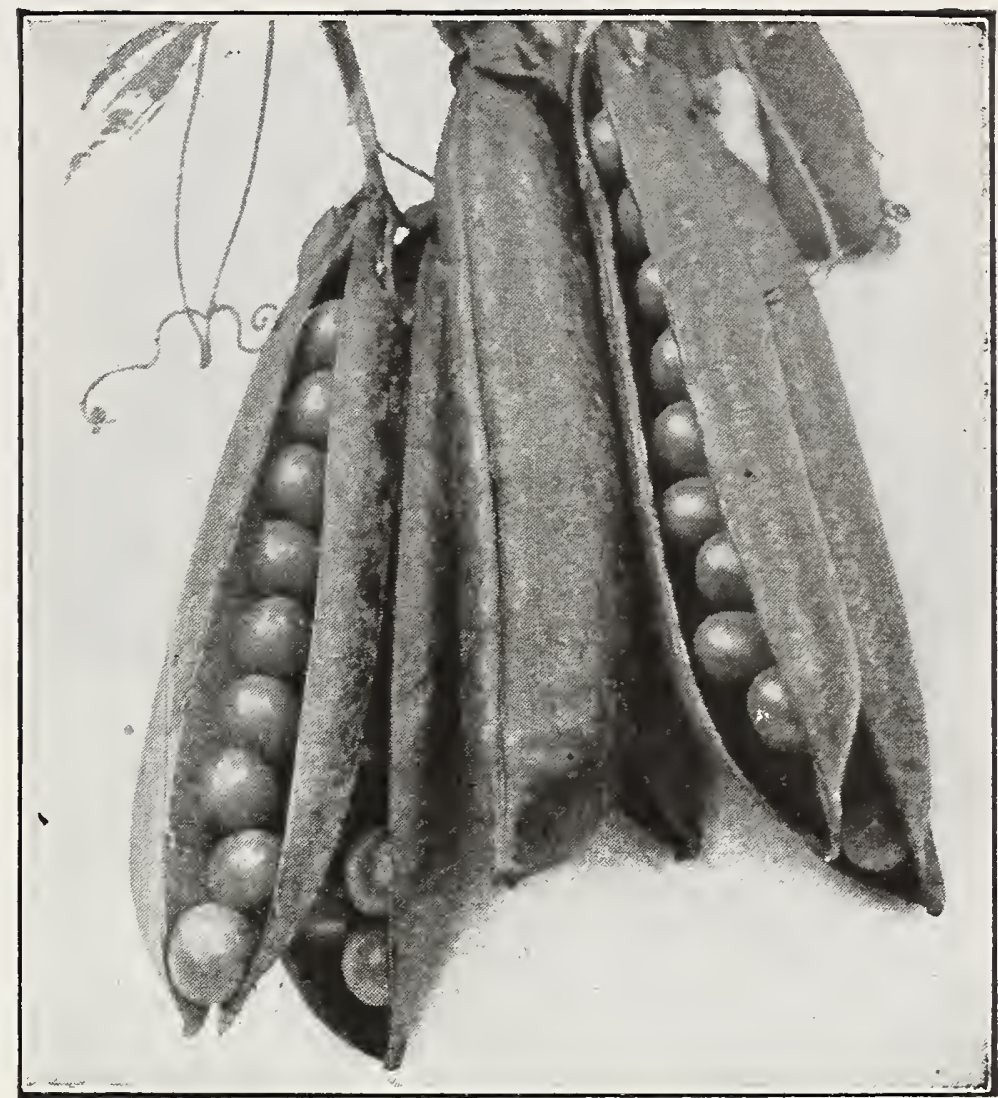

Wilson's Delicious PEAS-Continued

American wonder. Height 12 to 15 inches; extra early; large pods and Peas of good quality. Lb. 40 cts.; 2 lbs. 75 cts.; 8 lbs. $\$ 2.75$.

Nott's Excelsior. Height 12 to 15 inches. Early: large pods; a favorite with home gardeners. Lb. 40 cts.; 2 lbs. 75 cts.; 8 lbs. $\$ 2.75$.

GRADUS, or PROSPERITY. Height $31 / 2$ feet Largest earliest and sweetest wrinkled Pea. Lb. 50 cts.; 2 lbs. 90 cts.; 8 lbs. $\$ 3.25$.

IITTIE MARVEI. Very large pods; great yielder.

Only 15 inches high.
Lb. 40 cts.; 2 lbs. 75 cts.; 8 lbs. $\$ 2.75$.

IAXTONIAN (Dwarf Gradus or Blue Bantam) Height $11 / 2$ feet. Immense pods, and large peas of finest flavor. Very early. Lb. 50 cts.; 2 lbs. 90 ets.

Champion of England. A well-known standard late crop; large pods and peas. Height 5 feet. Lb. 40 cts.; 2 lbs. 75 cts.; 8 lbs. $\$ 2.75$.

Telephone. Standard late-crop sort; immense pods and peas. Height 4 feet. Lb. 40 cts.; 2 lbs. $75 \mathrm{cts}$.; 8 lbs. $\$ 2.75$.

Dwarf Sugar. Edible pods. Cook like string beans. Height 18 inches. Lb. 50 cts.; 2 lbs. 90 cts.

\section{Sweet PEPPERS or Hot}

All, 10 cts. per liberal packet.

One ounce will produce about 1,000 plants. Ready for the table in 100 to 120 days.

CULTURE-Same as Eggplant. See page 10. ChINESE GIANT. Very large; sweet and mild. Oz. 60 cts.; $1 / 4$ lb. $\$ 2.00$

The following sorts all $40 \mathrm{cts}$. per oz.; 1/4 1b. $\$ 1.50$. Bull Nose or Iarge Bell. Bright red; hot. Large; regular shape.

Ruby Giant. Large fruits. Flesh solid, sweet, and mild. Ruby scarlet when ripe.

Neapolitan. A large mild bright red sort, very eariy and exceedingly productive.

Sweet Mountain. Large; regular in shape; mild Havor.

GROW MTAT - SAVTNG VFGTTABIES

Certain garden products, such as Beans and Peas, rich in protein, are partial meat substitutes and supply much nourishment in small bulk. Grow this class of food liberally.

We: are always pleased with the seeds we get from you and you are always prompt in filling our orders, for which we thank you. - HARRY T. WIGGINS, N, J. 


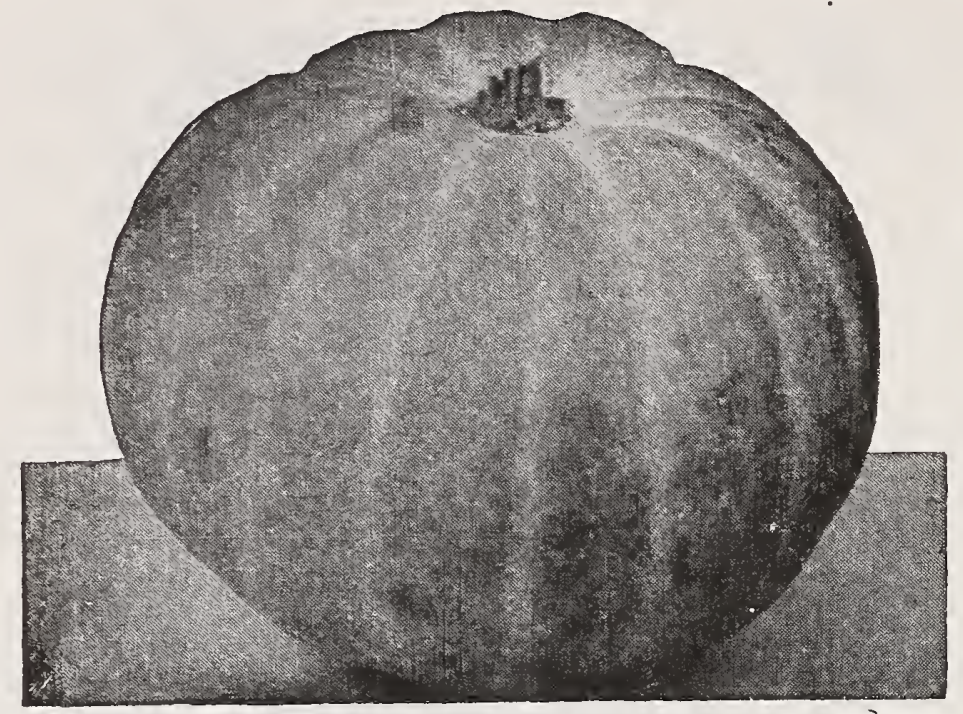

Mammoth Fing Pumpkin.

\section{Grow PUMPKINS In Your}

ekt, 10 cts.; oz. 20 cts.; 1/4 1b. 60 cts.; 1b. \$2.00except Irammoth King.

One ounce will plant about 30 hills.

ready for the table in 75 to 120 dags.

CULTURE-Sow early in May; make hills 8 to 10 feet apart each way; 4 to 6 seeds in the hill. When plants come up thin to two or three. Pumpkin seed can be sown with corn, in about every fourth hill.

IARGF CFrFsF, or PIr. Yellowish brown skin; deep yellow, fine grained flesh

sugar, or New Ingland Pie (also called winter Iusury). Orange fruits; yellow, tender flesh. Fine for pies.

TAMTOTF KING, or FOTIRON. Produces immense Pumpkins, sometimes weighing 250 pounds. Dee orange skin; light yellow flesh, tender and fine. Plkt. 10 cts.; oz. 25 cts.; $1 / 4$ lb. 75 cts.; lb. $\$ 2.50$.

Don't throw away your radish tops-they make delicious greens when cooked like spinach.

\section{Crisp RADISHES Brittle}

\section{Early or Late}

Liberal Pkt. 5 cts.; $1 / 2$ oz. 10 cts.; oz. 15 cts.; $1 / 4$ 1b. 50 cts.; 1b. $\$ 1.75$.

One ounce will sow a row about 50 feet long

6 lbs. to an acre. Ready in 20 to 70 days.

CULTURE-Sow as early in the spring as the ground can be worked 1 inch deep, in rows loot apart, just enough seed so they will not require thinning. For succession sow every two weeks, Sow winter varieties in July and August. Take up before reezing and store in sand in cellar or pit, and the will keep all winter.

WITSON'S 20-DAY, OI ROUND SCARIFT, FARIY. White, crisp, tender flesh; rapid grower.

BOUND S CA I I T WIITE TIPPID, BARIY (Sparkler). For frames or outdoors.

scarlet Globe Shaped, Early. For forcing or for outdoor planting; crisp and tender.

French Breakfast, Olive-shaped; scarlet, white tip

ICICI $\mathbf{2}$. Long, white, crisp and tender. Fine forcer Iong scarlet. Very brittle and sweet; matures in about 3 weeks. Splendid sort.

Scarlet China (Chinese Rose). Firm and crisp; good for winter or summer; oblong shape.

White strasburg summer. Very large; cylindrical. White stuttgart. Solid crisp pungent flesh; the largest of the turnip-shaped sorts.

of space. Matures in about 7 weeks.

GOIDFN YFIIOW SUIMIMER, A splendid sort for summer sowing. Tender crisp flesh.

WINTPR ROUND BIACK. Crisp and tender

JAPANESF SAKURAJIMA (The Iargest Radish in the world). Grows sometinies 3 feet around and 2 feet long, in 70 days and is used like other radishes or cooked like turnips. In Japan these radishes take the place of potatoes. Sow in May. Pkt. 10 cts.; oz. 35 cts.

JAPANGSE COIOSSAI. Plant some of this great variety. it is oval-shaped, flesh and skin white, grows to immense size in 70 days and is as crisp as the smaller sorts: excellent keeper. Sow in May. Pkt. 10 cts.; oz. 35 cts.
With vegetables at the prices they bring now adays, who says it doesn't pay to plant a garden?

\section{Grow Plenty of SPINACH}

\section{The Broom of the Stomach}

Iiberal Pkt. 5 cts.; 0z. $10 \mathrm{cts}$; 1/4 1b. 25 cts.; 1b. 75 cts. -except New Zealand and $\mathbf{K}$ ing of Denmark.

One ounce will sow a row about 50 feet: 10 to 12 pounds to the acre. Ready for use in 40 to 60 days CULTURE-For spring and summer use, sow in April in rows 1 foot apart, and 1 inch deep, and for succession sow every two weeks up to August. For winter use, sow in September and cover with straw or other protection on the approach of cold weather. IING OF DENBARK (also called Imerald Standing, etc.). This variety is very slow to go to seed, continuing to grow and hold its fine quality after other sorts have gone. It makes very quick low growth, producing dark green leaves of large size and very much crumpled. It is ready for use as soon as other varieties. The quality is excellent. Pkt. 5 cis.; $1 / 2$ oz. 10 cts.; oz. 15 cts. $1 / 4$ lb. 35 cts.; 1b. $\$ 1.10$.

VICTORIA. Broad, dark green leaves of fine quality A great heat-resister.

VIIROFIAY, Thlck Ieaved. Very large, thick dark green leaves; fine.

IONG SEASON (Triumph). Remains long in cutting condition, being slow to run to seed. Dark green leaves. Second early.

SAVOY IEAVFD, or BIOOMSDAII. Quick grow ing; fine for fall sowing; crumpled leaves.

New Zealand. Grows well in hot weather. Soak seed before sowing. $1 / 2$ oz. 10 cts.; oz. 15 cts.

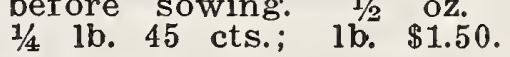

Ivery weed takes from the soil about three hundred times its weight in water during the season. Cultivation conserves moisture.

\section{Delicious RHUBARB}

Roots. 25 cts. each; $\$ 2.50$ per doz. Transportation charges extra.

Seed. Pkt. 10 cts.; oz. 25 cts.; $1 / 4$ lb. 75 cts.

SOW WIISON'S FVERGRFEN IAWN SEED For a Fine Velvety Irawn. See page 3.

How to make a lawn-See inside front cover.

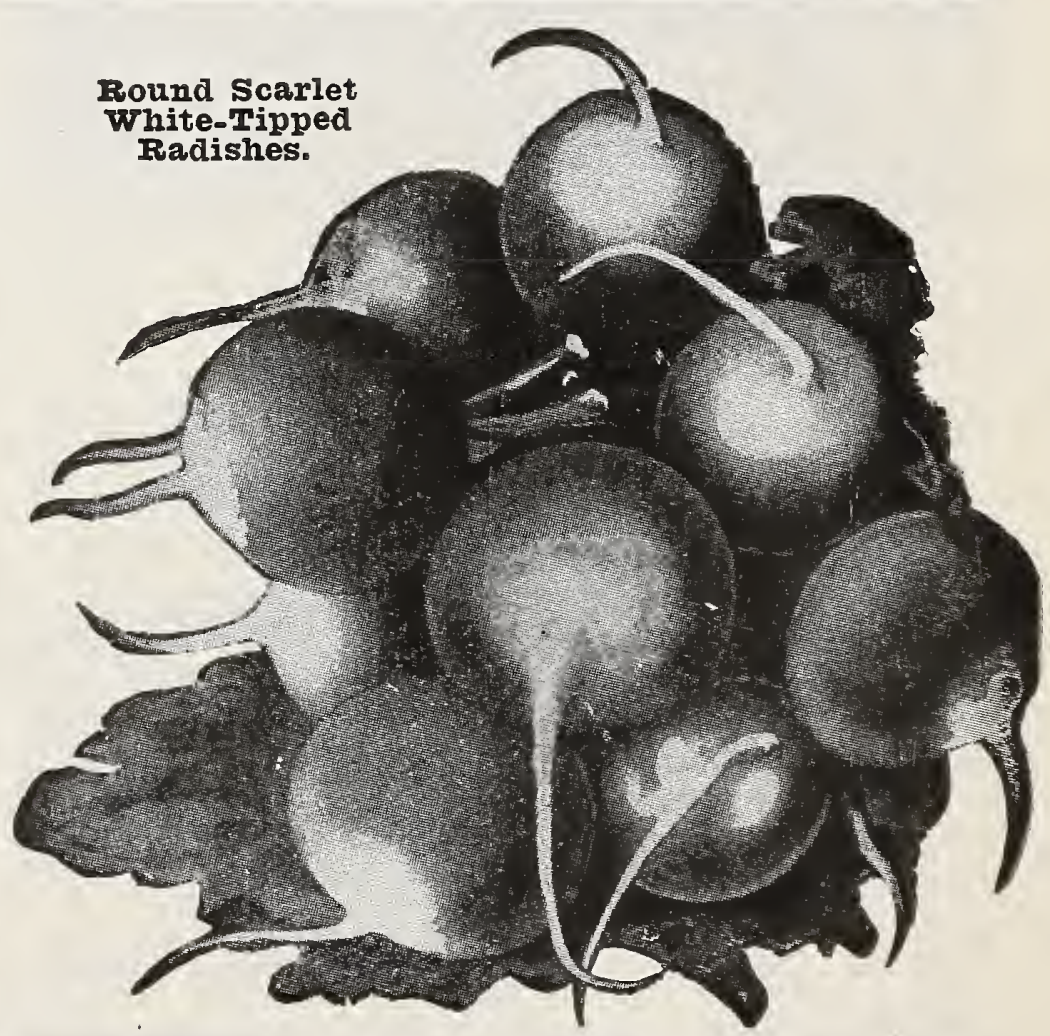

RFMPMBFR: Wilson's is the most get-at-ablo seed store in Newark. Always plenty of room to arive to our door. 


\section{Everybody Should Plant TOMATOES For vitamins}

\section{We shall have strong plants of several sorts in May.}

All $10 \mathrm{cts}$. per liberal packet except sunrise.

One ounce will produce about 1,000 plants. Ready for table 90 to 120 days from planting.

CULTURE-Sow in hotbeds or under glass in March or April, and when the young plants have made three or four leaves, transplant into shallow boxes or cold-frames, setting them 4 to 5 inches apart. When danger of frost is over, set out in the open. Seed can also be sown in the open ground.

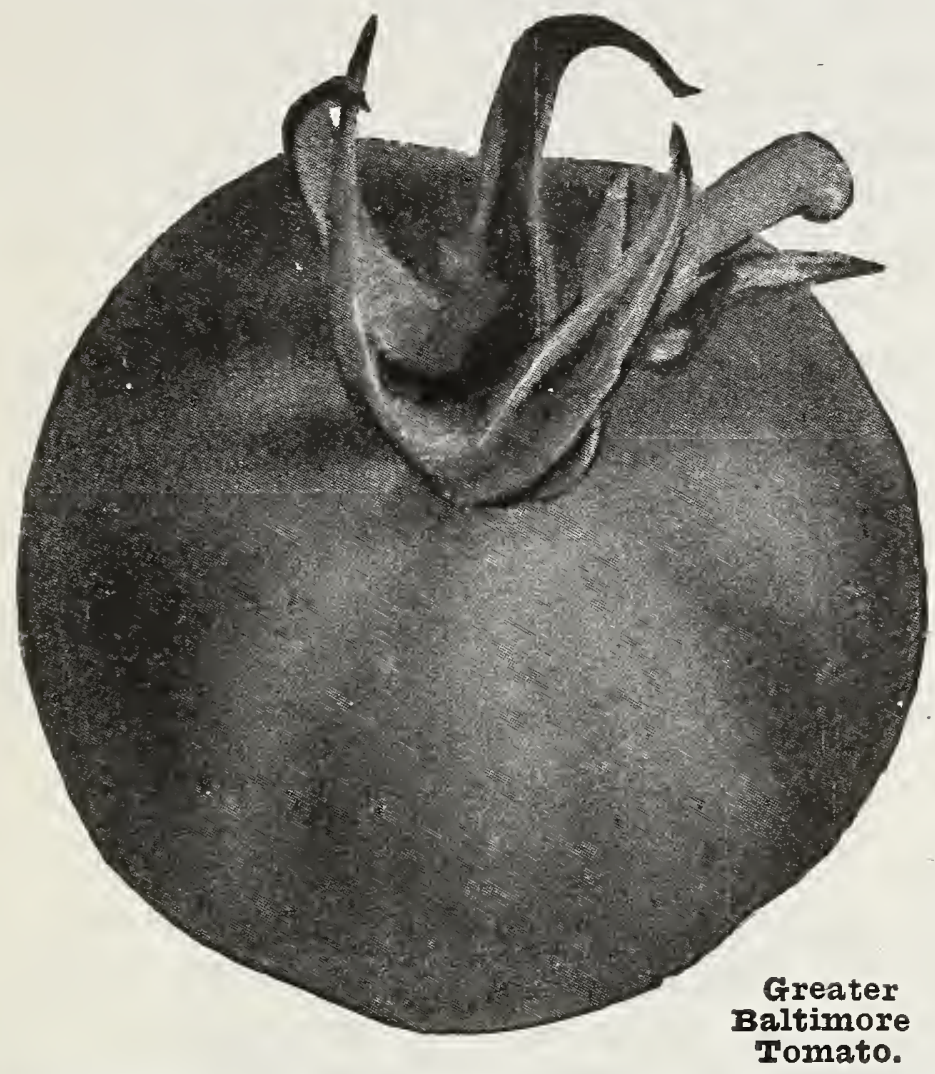

WHSON'S VERIBEST. Bright scarlet, globe-shaped fruits, free from cracking or tendency to blight. Firm flesh, free from acidity; vigorous, productive vines. $1 / 2$ oz. 25 cts.; oz. 45 cts.; $1 / 4$ lb. $\$ 1.50$.

GREATER BAITIMORE. Brilliant red fruits of medium size. Ripens evenly in clusters and is always free from ridges, cracks and blights. The best second early and main crop sort in existence. $1 / 2$ oz. 20 cts.; oz. 40 cts.; 1/4 lb. $\$ 1.35$.

PONDEROSA IMPROVED. Enormous purplish pink solid fruits free from acidity. Very productive mid-season sort. $1 / 2$ oz. 25 cts.; oz. 50 cts.; $1 / 4$ Ib. $\$ 1.85$.

GOIDEN PONDFROSA. Equals the red Ponderosa in size, but bears rich golden yellow fruits. Very striking when served sliced with red Ponderosa. $1 / 2$ oz. 35 cts.; oz. 65 cts.; $1 / 4$ lb. $\$ 2.25$.

John Baer. Firm bright scarlet globular fruits. Very desirable sort. $1 / 2$ oz. 20 cts.; oz. 40 cts.; $1 / 4$ Ib. $\$ 1.35$.

Matchless. Large, bright red, liong keeper; solid fruit. $1 / 2$ oz. 20 cts.; oz. 35 cts.; $1 / 4$ lb. $\$ 1.25$. Chalk's Early Jewel. Extra early; bright red fruit, smooth and solid. $1 / 2$ oz. 20 cts.; oz. 40 cts. $1 / 1$ lb. $\$ 1.35$.

Stone Improved. Fruits large, very solid, and of good quality. $1 / 2$ oz. 15 cts.; oz. $30 \mathrm{cts}$; $1 / 4 \mathrm{lb}$. $\$ 1.00 ; 1 \mathrm{~b} . \$ 3.50$.

SUNRISE. (For forcing under glass.) Rich scarlet, medium size, solid, delicate flesh. One of the best for indoors. Pkt. 15 cts.; oz. 75 cts.

\section{Small-Fruited TOMATOES}

Red Cherry, Pear, Peach, Plum; Yellow Plum, Peach, Pear, and Yellow Fusk Esteemed for preserves, etc. Pkt. 10 cts.; $1 / 2$ oz. 25 cts.; oz. 45 cts.

\section{TOMATOES FOR HEATTE}

"Tomatoes," wrote explorer Creels of arctlo fame, "were found to be our best vegetable, our experience being that the last cans were as good as the first; and no large eater of them was otherwise than in good health."

\section{SALSIFY or VEGETABLE OYSTER}

One ounce will sow a row about 50 feet long.

Reacly for table in 100 days after sowing.

CULTURE-Sow early in spring, in rows 15 inches apart and 1 inch deep; thin out to 6 inches apart in the rows; cultivate the same as carrots or parsnips. SANDWICH ISLAND. Large, white, smooth tapering roots. Pkt. $10 \mathrm{cts}$. oz. $40 \mathrm{cts} . ; 1 / 4 \mathrm{lb} . \$ 1.35$

POULTRY INANURE IN TOMATO HILIS

A good way to assure a bumper crop of to matoes is to bury a quart of poultry manure in the bottom of each hill, placing the manure deep enough so that the roots of the young plant: will not come into contact with the manure untll the vines are well started. See Fertilizers, page 4.

\section{SORREL For Soups and Salads}

CULTURE-Sow seed in any "good garden 'soil in shallow drills a foot apart. Thin plants to 2 few inches apart and remove seed stalks as soon as they appear.

Iarge-Ieaved. The largest leaved and best variety. Pkt. 10 cts.; oz. 25 cts.; 1/4 lb. 75 cts.; lb. $\$ 2.50$.

\section{SQUASHES For Summer or Winter}

One ounce will sow about. 20 to 40 hius; 4 pounds to the acre.

CULTURE-Sow in hills, when the apple is in bloom,-about 4 feet apart each way for the summer sorts, and 8 to 12 feet for the winter varieties, eight to ten seeds to the hill. When the plants come up and when danger of loss by insects is past, thin to three or four plants to the hill. Winter Squashee can be grown in cornfields in same way as pumpking.

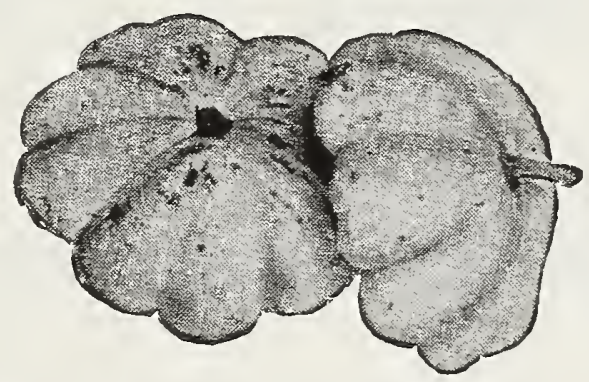

Patty Par Squash.

\section{SUMMER VARIETIES, BUSH}

All 10 cts. per liberal pkt.; 1/2 oz. 15 cts.; oz. 25 cts.; $1 / 4$ 1b. 75 cts.; 1b. $\$ 2.50$ Ready in 40 to 60 days.

WIISON'S SUMMrR CROORNYCK. Thick, yellow, dry flesh, of fine quality.

Giant Summer Crookneck. Double the size of the foregoing.

WIITE BUSF SCAIIOPFD. (Patty Pan.) Early: cream-white fruits.

Yellow Bush Scalloped (Patty Pan) (Golden Custard) Golden yellow flash; fine quality; very large.

Cocozelle, or Italian Vegetable Marrow. Long; green.

\section{Winter SQUASHES, Running Ready in About 100 Dajs.}

Delicata. Orange yellow, striped green; dry fesh of fine quality. Small but very prolific.

HUBBARD, CHICAGO WARTPD. A reliable, oldtime winter variety; large.

Vegetable Marrow, Fnglish. Very productive and deliciously flavored. Splendid for preserves.

SWISS CHARD. See under Beets, page 8. 


\section{Grow TURNIPS $\begin{aligned} & \text { For Roots } \\ & \text { and Tops }\end{aligned}$}

Cook the Tops as You Do Spinach

Plat. 5 cts.; $1 / 2$ oz. 10 cts.; 0z. 15 cts.; 1/4 lb. 40 cts.; 1b. \$1.25, except white and Purple-Top Milan and Tennoji.

One ounce will sow a row about 100 feet long; 3 pounds to an acre. Ready for use in 60 to 90 days. CUL'CURE-Sow seed in the open ground in April $1 / 2$ inch deep, in rows a foot apart, and thin to 4 to 6 inches in the rows. Be sure to have the soil rich and freshly stirred. Thin early and keep free from weeds. For fall and winter use sow in July and August.

If Turnips are strong, slice and soak them in water over night.

MIIAN, WHITE. Early; flat; smooth; white; tender and sweet; fine. Pkt. 10 cts.; oz. 25 ct.s.;

$1 / 4$ 1b. 75 cts.; lb. $\$ 2.50$

MIIAN, PURPII-TOP. Similar to above but with purple top. Pkt. 10 cts.; oz. 25 cts.; $1 / 4$ lb. 75 cts.; ib. $\$ 2.50$.

Golden Ball. Yellow flesh; medium size.

PURPIs-TOP WHITs GIOBE. Pure white flesh.

Fine for spring, summer, or autumn planting.

snowball. Pure white; quick grower.

Yellow Stone. Round; yellow flesh. Very fine keeper.

Tennoji Flat Japanese. Try it! A splendid white-

fleshed sort of large size. The flesh is very tender

and sweet; valuable for table or for stock.

Pkt. 10 cts.; oz. 30 cts.; 1/4 1b. $\$ 1.00$.

WIISON'S IMPROVRD PURPIF-TOP RUTABAGA.

Uniform size, shape and quality; desirable for

table use. Pkt. 5 cts.; oz. 15 cts.; 1/4 lb. 40 cts.

lb. $\$ 1.25$.

\section{AROMATIC HERBS MEDICINAL}

Every garden should contain a few herbs, as they are useful in many ways. They can be grown as edgings to walks, and their fragrance will be distributed by the brushing of clothing against the plants while passing.

CULTURE-Herbs delight in a rich, mellow soil. Sow early in spring in shallow drills, 1 foot apart: when up a few inches thin out to proper distances, or transplant. They should be cut on a dry day just before they come into full blossom, tied in bunches and hung up or spread thinly on a floor where they can dry quickly. Those marked with an * are perennial.

Basil, Sweet. For flavoring. Pkt. 10 cts.; oz. 25 cts. Borage. Excellent for bees. Pkt. $10 \mathrm{cts}$; oz. $35 \mathrm{cts}$. Caraway. Used in bread, etc. Pkt. 10 cts.; oz. 25 cts. Dill. For Dill pickles. Pkt. 10 cts.; oz. 25 cts * Fennel, Sweet. Pkt. 10 cts.; oz. 25 cts.

Fennel, Florence. Rounded thick leaf-bases. Pkt. 10 cts.; oz. 30 cts.

* Lavender. For perfuming. Pkt. $10 \mathrm{cts}$; oz. 50 cts. *Sage. For seasoning. Pkt. 10 cts.; oz. 75 cts.

Savory, Summer. Leaves and shoots are used for flavoring. Pkt. 10 cts.; oz. 40 cts.

*Sweet Marjoram. Leaves used green in summer and dried in winter for flavoring. Pkt. 10 cts.; oz. 40 cts.

*Thyme, Broad-Ieaved Bnglish. For seasoning and poultry stuffing. Pkt. $10 \mathrm{cts}$.: oz. $85 \mathrm{cts}$.
Planted the seeds in a coldframe on a Saturday and they were up on Wednesday like hair on a dog's back.

(Signed)

I. I. TREDW

(Mr. Treawell has sown wilson's seeds every year since 1913.)

\section{REMEMBER ! The most accessible Seed Store in Newark is WILSON'S, 79 Orange Street, just a few steps in from Broad Street. Plenty of room for your car right before the door!}

Newark, N. J., Nov. 19, 1925.

Everything is most satisfactory.

(MISS) 2. $\mathbf{K}$.

\section{Fresh Recleaned BIRD SEED, ETC.}

All our Bird Seed is fresh and clean and of the best quality obtainable. Do not confound "Wilson's" with the kind you buy in cartons in drug stores, etc. Canary seed (not mixed). Lb. 20 cts.; 5 lbs. 90 cts. Canary Seed (mixed with zape). Lb. 20 cts.; $51 \mathrm{bs} .90 \mathrm{cts}$.

Bape Seed (Bird Rape). Lb. 20 cts.; 5 lbs. 90 cts. Femp seed. Lb. 15 cts.; 5 lbs. 70 cts. Iettuce seed for Birds. $1 / 4$ lb. 15 cts.; lb. 50 cts. Sunflower seed for Parrots. Lb. 15 cts.; 10 lbs. $\$ 1.35$. Blue Maw (Poppy). 1/4 lb. 15 cts.; 1b. 50 cts. Cuttle Fish Bone. Oz. 5 cts.; Lb. 70 cts.

Bird Gravel (or Sand). Cartons only. $10 \mathrm{cts}$. each.

TRANSPORTATION CHARGES NOT INCIUDED IN ABOVI PRICES.

We try always to give a little more than expected, both in quality of goods and in efficiency of service.

The Milan Turnips are the most satisfactory for early spring sowing. They never fail to produce a crop and in a remarkably short time.

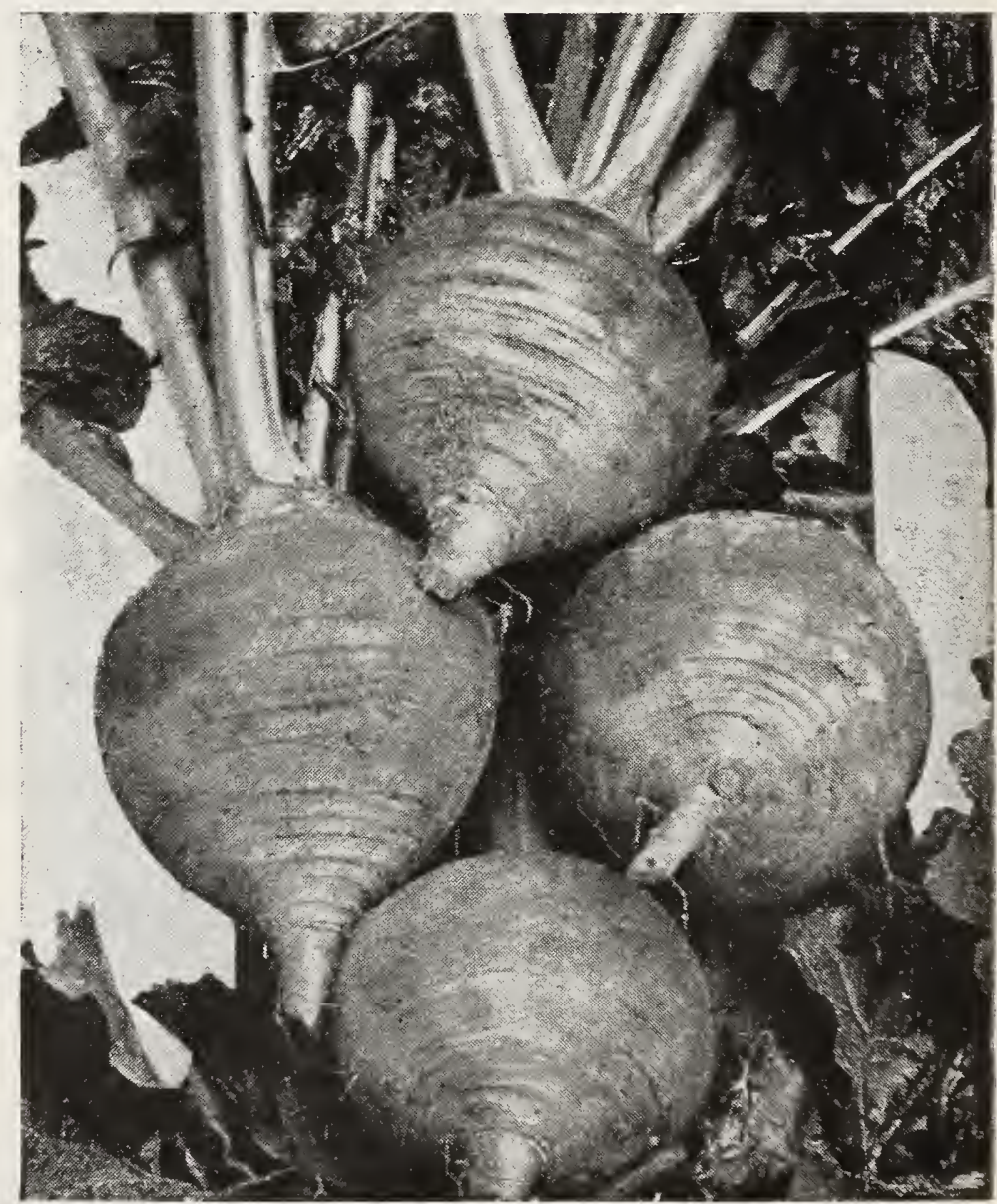

Wlison's Improved Purple-Top Rutabaga. 


\section{HOW TO GROW}

\section{The Wilson Quality Flower Seeds}

The Alphabetical Arrangement of Our Catalog Makes an Index Unnecessary All our Flower Seeds are delivered free anywhere in the United States. Our packets contain a liberal quantity of seed.

\section{SOWING ANNUATS}

All annuals can be sown in the garden in May when the ground is warm, either in a seed-bed or directly where they are to grow. There are some, such as Poppies, Eschscholtzia, Mignonet te, Centaurea, etc., which, on account of lack of fibrous roots, cannot be transplanted without great setback. These should be sown, either broadcast or in rows, in the location dseired. Most' annual flowers, however, benefit by being transplanted so as to develop a better root-system. These are better started in a coldframe or a specially prepared seed-bed, deeply dug and finely sifted on top. Most flower seeds are small and should be covered with only about $1 / 8$ inch of soil; the very fine seeds are simply pressed into the soil. Water carefully through a fine rose, so as not to wash the seed out, and keep the soil moist. On warm, sunny days some shade should be given. When the seedlings are large enough to handle, they can be transplanted 1 inch apart into another seed-bed, or if they are not too close together, they may be left in the original bed until large enough to transplant into permanent places. Always remember that flowers need good soil, an open sunny situation, and sufficient space between plants for proper development.

STARTING SEFDS IN HOTBEDS OR IN BOXES

Many annuals, such as Snapdragons, Stocks, Asters, Carnations, Cockscomb, Cosmos, Dahlias, Pinks, Heliotrope, Lobelia, Pansies, Petunias, Phlox, Salpiglossis, Salvia, Vinca, Verbena, if sown outside do not bloom until quite late in the summer, but you can have them early if you sow the seed in except for Lobelias, and Stocks, which can be started as early as February. Sow either directly in the hotbed in shallow drills on in pans or boxes. The soil should be light, finely sifted, and well watered before sowing. Scatter seeds evenly, but not too thinly. After sowing press the soil down with a flat board and cover with newspaper to prevent too rapid evaporation. This covering must be removed as soon as the seedlings are up. Always water through a fine rose, and only when necessary, with tepid water and as much as possible in the forenoon or midday on bright sunny days, for if the soil is too wet over night, the small seedlings will become chilled and damp or rot off. When seed1 inch apart or singly into small pots, shifting into larger ones if necessary. Ventilate more or less according to the weather and gradually harden the plants, preparatory to setting them out when all danger of frost is past and the soil is warm. Cultivate frequently and stimulate plant growth by applying a top dressing of sheep manure, poultry manure or bonemeal to the soil at frequent intervals. See inside front cover page for fertilizers, etc. This will keep up a vigorous, healthy growth. Keep seed-pods removed; never allow withered flowers to remain on the plants if you want them to bloom right through the season.

\section{HOW TO GROW PERENNIAIS, INCIUDING THOSE WHICH ARE BIFNNIAIS (IAST- ING BUT TWO YEARS)}

Perennials will bloom the second year from seed and are permanent thereafter. Most of them are so hardy that they do not require protection during winter. We find among them some of our most beautiful cut-flowers and many of the old-fashioned favorites of grandmother's garden. A hardy border is a continual source of joy; from earliest spring to late autumn it will be resplendent with color. Once established, such borders need no other attention than to be kept free from weeds and to be given an occasional topdressing with fertilizer.

\section{WHEN TO SOW PERENMIAIS}

Many of the hardy flowers will bloom the first year from seed if sown in the hotbed in February or March. Outdoors they may be sown any time from May 1st to August. A coldframe is an ideal place, but, if you have no coldframe, prepare a seedbed of finely sifted light soil, made rich by adding and mixing with it poultry manure, sheep manure, or bonemeal. See inside front cover. Sow the seed in shallow drills or squares of suitable size, partitioned off with laths; cover $1 / 8$ inch or more, according to the size of the seed-the very fine ones should only be pressed into the soil with a flat board-water gently but thoroughly through a fine rose and do not allow the soll to become dry whlle the seed is in process of germination, for as soon as the seed has sprouted and until it becomes a plant with roots, its life depends entirely on soll. moisture. Seed-beds must be shaded from the sun in summer and carefully watched and watered until the plants have made from four to five leaves. While most hardy flower seeds germinate in from eight to fourteen days, there are some which take a month or more, so do not become impatient. If seedlings come up too thick, pull out some and transplant elsewhere in boxes or other seed-beds. and when the plants are large enough set them out in their permanent places. This, however, should not be done later than October 1st, in order to allow sufficient time for them to take firm root before frost. Cover with leaves or salt hay, applied after the ground is frozen. Too early covering sometimes causes heating and consequent decay of plants, and it also encourages field-mice.

\section{EXPLANATION OF IETTERS USED IN} THIS SECTION

HA. Hardy Annual. TP. Tender Perennial.

FFA. Falf-Fardy Annual. HB. Hardy Biennial.

FP. Hardy Pereunial. TB. Tender Biennial. FPl. Hardy Perennials that flower the first year if sown early.

4 SFASONS FERTIIIZER-Splendid for Flowers. See page 5 .

\section{Flowers of the States}

Nearly all the States have adopted an ofncial flower, and in those that have not the question is up for discussion. The flowers by States follow:

Arizona, Giant Cactus.

Arkansas, Apple Blossom.

California, Golden Poppy.

Colorado, Blue Columbine.

Connecticut, Mountain Laurel.

Delaware, Peach Blossom.

Florida, Orange Blossom.

Georgia, Cherokee Rose.

Idaho, Syringa.

Illinois, Violet.

Indiana, Carnation.

Iowa, Wild Rose.
Kansas, Sunflower

Kentucky, Trumpet Vine.

Louisiana, Magnolia.

Maine, Pine Cone and Tassel.

Massachusetts, Mayflower.

Michigan, Apple Blossom.

Montana, Bitter Root.

Nebraska, Golden Rod.

Nevada, Sage Brush.

New Mexico, Cactus.

New York, Rose.

North Carolina, Daisy.
North Dakota, Wild Prairie Rose Ohio, Scarlet Carnation.

Oklahoma, Mistletoe.

Oregon, Oregon Grape.

Rhode Island, Violet.

South Dakota, Pasque Flower.

Texas, Blue Bonnet.

Utah, Sego Lily.

Washington, Rhododendron

West Virginia, Indian Paint Brush Wisconsin, Violet.

Wyoming, Indian Paint Brush. 


\section{General List of the Wilson Quality Flower Seeds}

\section{Wilson's Haphazard}

Flower-Garden Mixture

Sow some of this broadcast in any out-of-theway place and you can be sure of plenty of flowers for cutting. Pkt. 5 cts.; 1/4 oz. $20 \mathrm{cts}$; $1 / 2 \mathrm{oz}$ 30 cts.; oz. 50 cts.; 1/4 1b. $\$ 1.00$
Wilson's New Cut-Flower Seed Mixture

Every item in this new mixture is suitable for cut flowers and is so planned as to produce a continuous array of bloom all summer. Sow it between your vegetable rows, in odd corners and on vacant lots. Pkt. $10 \mathrm{cts}$.; $1 / 40 z .25 \mathrm{cts}$. 1/2 oz. 40 cts.; oz. 65 cts.

\section{Wilson's Gorgeous Giant Spencer Sweet Peas}

\section{All 10 cts. per pkt.; 40 cts. per ounce-} except quoted otherwise.

One ounce will sow a single row 20 feet long

A deep, rich, moist soil is best suited to Sweet Peas, hence a trench should be dug $11 / 2$ feet deep, and nlled with loam mixed with bone-meal or well-rotted stable manure. Thoroughly pulverize the soll, giving level cultivation. Make your drills not over 3 inches deep and 6 to 12 inches apart and cover the seed to the full depth of the drill. Do not draw the earth up to the stems, as that causes stem-rot. Sow plentifully, and thin plants to about 2 or 3 inches apart. About 1 foot away from each row or drill cover the ground with a layer of straw or lawn clippings, and when watering instead of playing your hose directly on the plants, turn it on the straw or mulch, and you'll be surprised how the plants will thus keep supplied with moisture, insuring fine healthy blooms. Spring sowings should be made as soon es the ground can be prepared.

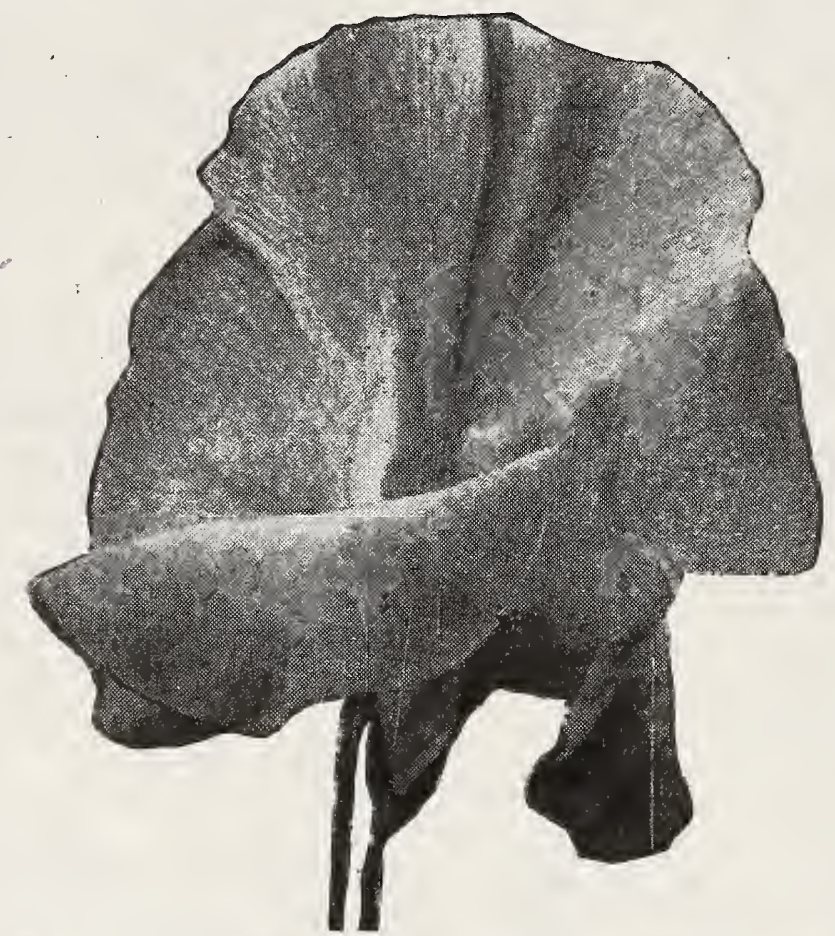

Miss California (New) Spencer Sweet Peas. Wonderful Orange-Salmon.

\section{White-}

Constance Iinton. Very large flower. Black seed. Perfected White Spencer. Finest of all whites.

Pink-

Eercules, Rosy pink; very large.

\section{Cream-Pink-}

Picture. Cream-pink apricot suffusion. Fine.

Miss California. Cream-pink orange salmon.

Pkt. 25 cts.

Salmon and Carmine-

Barbara. Salmon-orange.

Doreen. Bright carmine. Pkt. 20 cts.; oz. $\$ 1.00$. George Herbert. Rosy carmine.

Renown. Carmine rose.

\section{Maroon-}

King Manoel. Giant maroon

\section{Blue-}

Mrs. Tom Jones. Bright delphinium blue. Extra. Colne Valley. Light blue.

wedgewood. Clear blue.

Lavender and Purple-

Royal Purple. As named.

Hawlmark Iavender, Pale blue-lavender.
Scarlet and Crimson-

Crimson Kring. Rich glowing crimson. Campfire. Brightest sunproof-scarlet.

Pkt. 20 cts. oz $\$ 1.00$

Royal Scot. Brilliant scarlet. Pkt. 15 cts.

Bicolor, Striped, Picotee-Edged-

Elsie Ferbert. White, pink edge.

MIs. C. W. Breadmore. Primrose-edged rose Dainty. White; rose-pink edge.

Mrs. Townsend. White-edged bright blue.

\section{WILSON'S SILVER-GILT MEDAL MIXTURE OF SPENCERS}

A beautiful blend of all the best and newest varieties. No better assortment of colors can bo had at any price. Pkt. 10 cts.; oz. 35 cts.; $1 / 4$ lb. $\$ 1.25$; $1 \mathrm{~b}$. $\$ 4.00$.

\section{WILSON'S SUPERB MIXTURE OF} GRANDIFLORA SWEET PEAS

These are the old-fashioned sorts with mediumsized flowers; very fragrant. Extra fine. Pint. 5 cts.; oz. 20 cts.; $1 / 4$ 1b. 60 cts.; 1b. $\$ 2.00$.

\section{MAGNIFICENT NEW SWEET PEAS}

MrSS CAIIFORNIA. The beautiful coloring of the flower cannot be conveyed in a word picture, as the blending of the shades is so perfect and wonderful. The general effect is a rich, beautiful orangesalmon cream pink of a distinctly new shade. The flowers are large, beautifully waved and borne in fours on long, stout stems. The plant is an exceptionally vigorous grower and cannot but give satisfaction to everyone. Pkt. 25 cts. CAMPrIRE. In Campfire we have the brightest scarlet sun-proof Sweet Pea ever stands out is the last word in vivid color and class. The flowers will stand the hottest sunshine, in fact, the brighter the sun the better the color. They are of fine size and borne in profusion on plant's of geat vigor. This variety is highly recommended for garden decoration and cut-flower use. Pkt, 20 cts.; oz. $\$ 1.00$.

DOREEN. Doreen is a huge, bright carmine Sweet Pea, much larger and brighter than all other carmine varieties we have tried. The color is bright and outstanding. Doreen will be popular with exhibitors on account of its size. The plant is a most vigorous grower and bears a profusion of four blossom sprays. Pkt. 20 cts.; oz. $\$ 1.00$ 1 Pkt. each of the 3 sorts for $50 \mathrm{cts}$. 


\section{Wilson's Superb American Asters}

\section{"Foretelling that Autumn draweth nigh"}

CUITURE-Asters should have an open, sunny position. They prefer good, heavy, loamy soll, en riched with 4 Seasons Fertilizer, AND THE ADDITION OF PLANT IIME, See page 4. Do not grow them on the same ground year after year. For early flowering the seed should be started Indoors in March or Aprll. Transplant I inch apart when they have made their third leaf and transfer to thelr

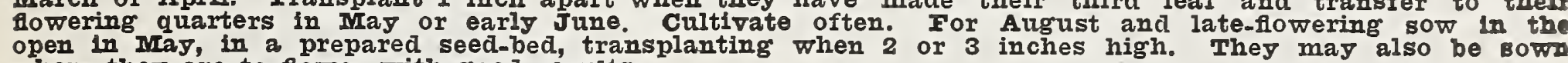
where they are to flower with good results.

The height and earliness of the varlous classes are indicated by figures and letters, thus: 1 , vers dwarf, to 6, tallest growing; $\mathbb{E}$, extra early; $\mathbf{M}$, medium, and $\mathbf{I}$, late.

All These 10 Cents Per Packet.

Invincible Aster M6

Healthy, robust plants of branching growth, producing on 2-foot long stems, massive, well-formed flowers, which are always perfectly double. These Asters are wonderfully prolific and continuous bloomers from summer until frost.

Purple Iavender Rose Pink White
Indxed. All colors. $1 / 4$ oz. $75 \mathrm{cts}$.

Imp'd American Victoria (Daybreak) 4M

Fine for beds or borders where an even growth and a mass of flowers are wanted for effect; the sturdy upright plants, 12 to 14 inches high, carry not less than 30 flowers each, producing a mass of color unequalled. Blooms from early August till late October.

Shell P1nk Purity (Purest White)

Early Branching or Royal Asters 4M

One of the best Asters of recent introduction, and might briefly be described as an early flowering form of our Late-Branching, coming into bloom in July or early August.
Iavender
Shell Pin
White
Finest Mixed. All colors.

\section{Astermum Asters 6M}

A strain of Comet Asters which, on account of their size and Chrysanthemum-like appearance, have appropriately been named Astermums. The plant grow about 2 feet high.

White
Parple
Plint
Mixed. All colors.

Late-Branching Asters 6L

The plants form strong, branching bushes 2 to 21 feet high, bearing on long, strong stems flowers which, under ordinary cultivation, average 5 inches across. They are usually at their best during September.

\begin{tabular}{|c|c|c|}
\hline $\begin{array}{l}\text { Azure Blue } \\
\text { Crimson } \\
\text { Iratender }\end{array}$ & White & $\begin{array}{l}\text { Purple } \\
\text { Rose-PInt } \\
\text { Shell-PInt }\end{array}$ \\
\hline
\end{tabular}

\section{Crego's Giant Comet Asters 4M}

We consider this the finest and largest of all Comet Asters, bearing immense fluffy flowers, as fine as any Chrysanthemum, and when cut keep in good condition longer than any other of this type.

White Shell Pink Iravender Pose

Mixed. All colors, $75 \mathrm{cts}$. per $1 / 4$ or

Queen of the Market Asters 3EE

A first-class early flowering Aster, coming into flower in July, of branching habit; flowers of good size and borne on long stems, making them oxceedingly valuable for cutting; 1 foot.

Crimson
Iavender
Mixed. All colors. $4 / 4$ Oz. 50 cts.

My Asters this past summer, sown from your seed, were superb. Everybody raved about them. I want more next spring.

H. H., Maplewood, N. J., Oct. 25, 1924.

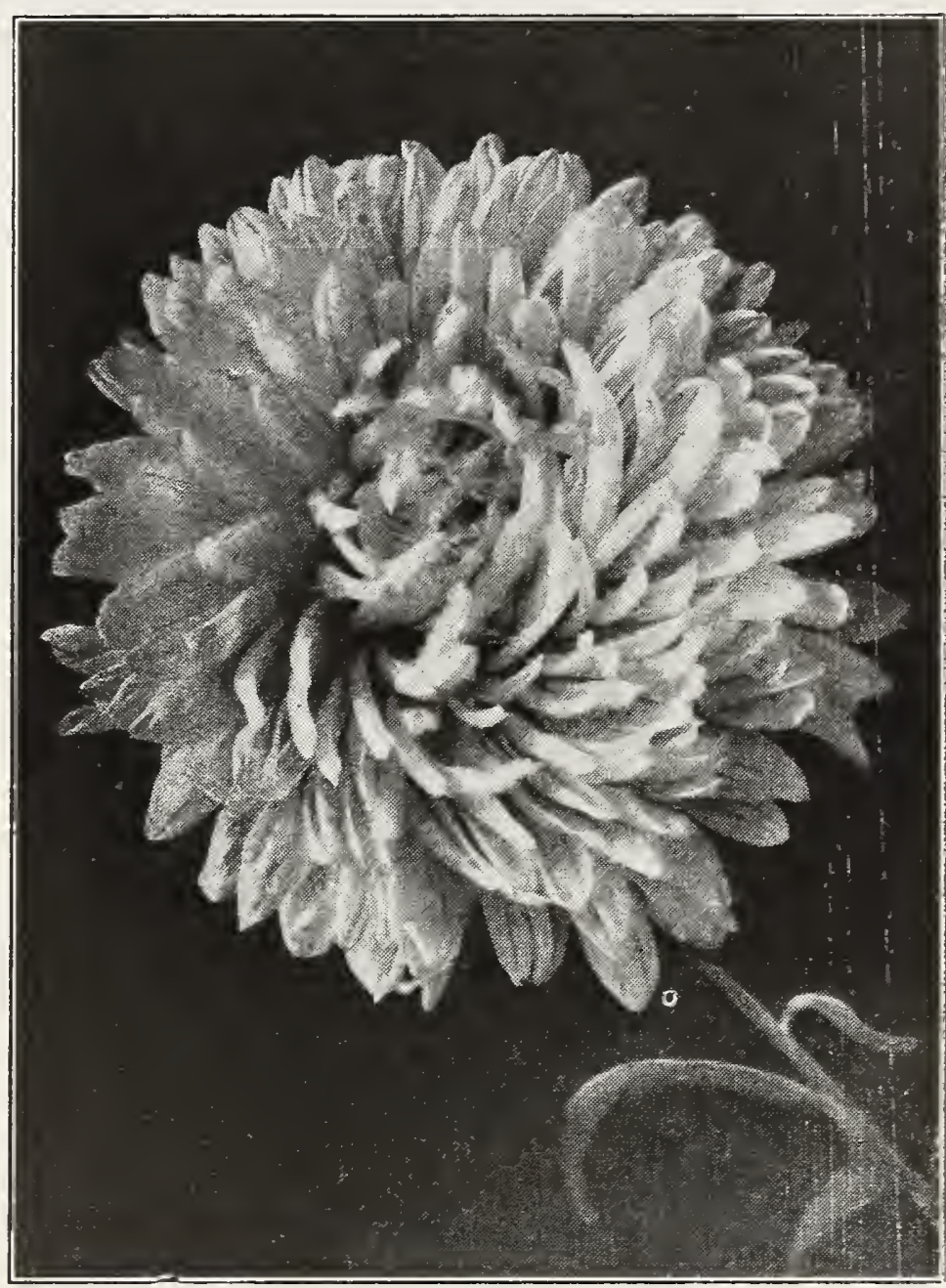

Crimson Giant Aster.

\section{NEWER ASTERS OF MUCH MERIT}

Crimson Giant Aster

This variety has all the good qualities of ou Superb Late Branching type, but is of uprigh growth, with extra large, densely double, rich blood crimson flowers, few under 5 inches across, on stems 15 to 18 inches long, making a brilliant bed or border. 15 cts. per pkt.; 2 pkts. 25 cts.

\section{Heart of France Aster}

This recent introduction is the largest flowering of the very dark red sorts; plants grow about 24 inches high, nicely branched, bearing in September their large, rich, deep ruby-red flowers on long. strong stems. $15 \mathrm{cts}$. per pkt.; 2 pkts. 25 cts.

\section{California Giant Asters}

A beautiful new variety with very large flower of the Crego type, and with the habit of growth and long stems of the Branching sorts. Stand up well after being cut. Very attractive sort. Each color: Pkt. 15 cts.; 1 pkt. each of the 3 colors, 40 cts. Deep Rose Iight Blue

Dark Purple

New Extra Early Pink Aster

Has a much larger flower than Queen of the Market and comes into bloom 7 to 10 days earlier It is of the lateral habit of growth, the plant produces 6 to 8 stems 15 to 20 inches long, each bearing a large perfectly double flower. The flower is of the Comet type, 4 to 5 inches across and of a beautifu? light rose pink. Pkt. $15 \mathrm{cts}$; 2 for $25 \mathrm{cts}$. 


\section{Wilson's Mammoth Double-Flowering Zinnias}

HARDY ANNUAIS. BIOOM CONTINUOUSIY FROM FARIY SUIMIFR TIII FROST.

\section{(Youth and Old Age)}

TrHE Zinnia has gained more steadily in popularity than any of our annuals because of the interest taken in it by plant-breeders who have tried to excel one another in improving existing forms and bringing out new ones each year. We are offering this season some of the newer forms which will, we feel sure, at once become popular in your garden. $\mathbb{E}$ ew, if any, of the annuals have greater utility value. In the mixed border they may be had in bloom from early summer until frost, and they are splendid when used as cut flowers. To get best results, seed should be sown either indoors in a sunny window and the plants transplanted to the garden early in May, or started outdoors and plants transplanted later. Leave at least 2 feet between plants as they are robust growers and need sufficient space to attain maximum development.

Wilson's Mammoth Double Giants. Flowers of gigantic size, perfect form, densely double and very brilliant. The strain we offer represents the highest grade of perfection and cannot be excelled. Height 2 to $3 \mathrm{ft}$.

Giant scarlet. Very rich.

Giant Purity. Pure white; exquisite.

Giant Golden Ball. Pure golden yellow. Free flowering.

Giant violet. A rich and impressive color.

Giant Iemon Queen. A pleasing and delicate shade of lemon-yellow.

Giant Flesh Color. Splendid flesh pink; a most attractive color.

Giant Rose Queen. Perfect shaped flowers of great substance; the most captivating rose color imaginable.

All of the above same price.

Pkt. 10 cts.; $1 / 8$ oz. 30 cts.; $1 / 4$ oz. 50 cts.; $1 / 2$ oz. 85 cts.; oz. $\$ 1.50$.

collection: 1 pkt. each of above 7 colors, $60 \mathrm{cts}$. Giant Mixed. All colors. Pkt. 10 cts.; 1/8 oz. 25 cts.; $1 / 4$ oz. $40 \mathrm{cts}$.

WITSON'S GIANT PICOTEE TYPE. Choice Mixed Colors. A remarkable new and distinct class with beautiful double flowers, each petal being distinctly tipped with various shades, resembling the Picotee Carnations.

Pkt. 25 cts.

WIISON'S SPECIAI MIXTURE. Contains everything that is new, and-rare in Zinnias, including the Dahlia-Flowered, Picotee and Mammoth types, and is sure to produce the most pleasing and satisfactory results. Pkt. 20 cts.; 3 pkts. 55 cts.; $1 / 8$ oz. 60 cts.; $1 / 4$ oz. $\$ 1.00$.

GIADIOIUS. Probably the most satisfactory of all the summer flowering bulbs since it is not exacting as to soil and is practically immune from insect pests. Blooms may be had all summer by planting every week or ten days from April to end of July. Our Gold Medal Rainbow Mixture is unequalled. Let us prove it. See inside back cover.

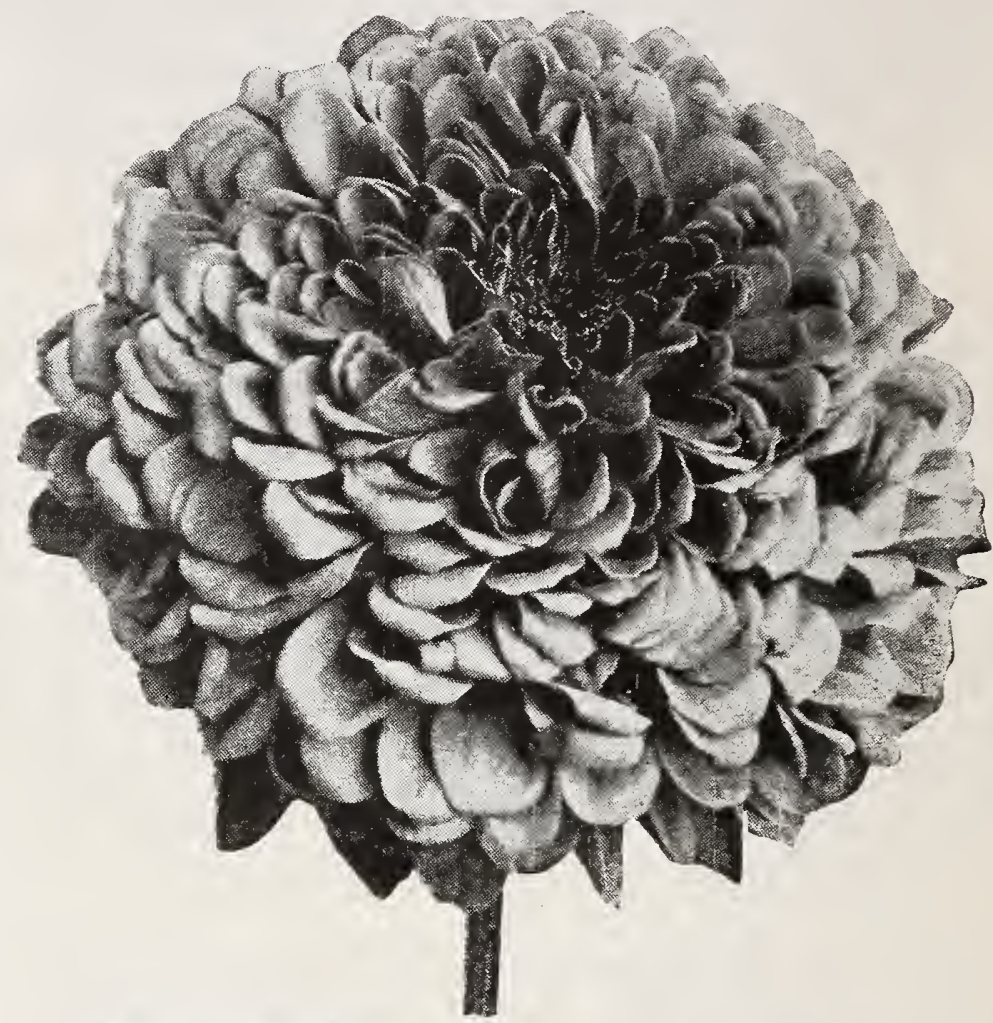

Single specimen of

Wilson's New Giant Dahlia Flowered Zinnia.

Wilson's New Giant Cactus, or Dahlia Flowered Zinnias The plants of this new race many flowers with stout stems. sturdy and produce broad petals are closely imbricated, sometimes seeming almost to be piled one upon the other. The flowers often measure 4 inches in depth and 6 to 8 incmhes in diameter. In general appearance, the flowers compare with the Show Dahlias. Old Rose. The name itself adequately describes this beautiful sort; the charm and beauty of the flowers place it in a class by itself. Pkt. 25c. Crimson Monarch. Immense flowers, often 8 ins. in diameter under good cultivation. Vigorous grower. A marvelous production. Pkt. 25 cts.

Fxquisite. The flower's resemble a large decorative dahlia. A lovely shade of rose deeper toward the center. Pkt. 25 cts.

Polar Bear. Monstrous flowers of the purest white borne in remarkable profusion. The best white zinnia. Pkt. 25 cts.

Meteor. A rich glowing deep red-darkest of all. Fine form with good depth of petal. Very larso and extremely floriferous. Pkt. $25 \mathrm{cts}$.

Golden state. An immense orange yellow. changing slightly as the flower ages but at all times worthy its name. Exquisite. Pkt. 25 ct's.

Dream. Fine deep lavender, turning to purple. A new and desirable shade. Pkt. 25 cts. Special mixture of above and others color. Pkt. 20 cts.

Collection: 1 pkt, each of the 7 named sorts ror $\$ 1.50$.

\section{DWARF DOUBLE LILLIPUT ZINNIAS}

INIMUNE FROM INSECT PESTS.

Charming plants for the border, only I foot high and literally covered with tiny globe- or ball shaped, very double Zinnias resembling the pompon dahlia. In bloom from June until frost. The are very satisfactory for edging beds or borders. Plt. $10 \mathrm{cts.;} 1 / 4$ oz. $35 \mathrm{cts.;} 1 / 2$ oz. $60 \mathrm{cts.;} 0 z$. $\$ 1.00$. WONDERTUL FOR EDGING FLOWER BEDS OR BORDERS. 


\section{Ageratum}

(Floss Flower). HA. Without doubt the most satisfactory blue bedding plant for our trying climate. Rain rarely spoils the flowers, and the colors do not fade. A September sowing will give plants to bloom all winter indoors. If you want a bed of lovely color use AGERATUM for an edging to CALENDULA, both easily raised from seed.

Blue Perfection. Deep blue; compact; 9 inches. Pkt. 10 cts.

Imperial Dwarf Blue. 8 inches. Pkt. 10 cts.; $1 / 4$ oz. 35 cts.

Imperial Dwarf, white. 8 inches. Pkt. 10 cts.; $1 / 4$ oz. 35 cts.

Iittle Blue Star. Light blue. 4 to 5 inches. Pkt. 25 cts.; 1/8 oz. $\$ 1.00$.

Mixed Colors. Pkt, 10 cts.; 1/4 oz. 25 cts.

AGROSTrmina Coeli rosa (Rose of Heaven). HP. 2 feet. Fine for dry situation. Pkt. 10 cts.

ACHIIIEA (Yarrow). HP1. White (Ptarmica, "The Pearl"). Grows about 2 feet high, with heads of purest white, double flowers. Pkt. 25 cts.

ACONITUIM (Monkshood). HP. Blue (Napellus). Long spikes of curiously shaped blue flowers. Fine for shady places. 3 to 5 feet. Pkt. $10 \mathrm{cts}$. A TSSUT0 $\begin{aligned} & \text { (Sweet Alyssum) HA. Covered } \\ & \text { from early summer to fall with }\end{aligned}$ small, pure-white flowers of a peculiar, delicate fragrance. One f the prettiest and most generally used edging plant's.

Iittle Gem. HA. White, Dwarf, compact; 6 ins Pkt. 10 , cts.; $1 / 4$ oz. 35 cts.; oz. $\$ 1.00$.

sweet (A. maritimum) HA. White. Pkt. 10 cts.; $1 / 4$ oz. 25 cts.; oz. 60 cts.

Iilac Queen. HA. Pale lilac; very dainty. Pkt 10 cts.; 1/4 oz. 35 cts.; oz. $\$ 1.00$.

Yellow (A. saxatile compactum, Basket of Gold). HP1. Blooms the first season if sown early indoors; fine for rockwork; 1 foot. Pkt. 10 cts.

\section{Amaranthus HA. Eifrective annuals with $\mathrm{s}$ trive annuals,} growing from 2 to 4 feet
high; useful in borders of tall plants or for the centers of large beds. They thrive in sunny locations in soil not too rich.

Iove-Iies-Bleeding (A. caudatus). Drooping crimson flowers. 2 feet. Pkt. 5 cts.; $1 / 4$ oz. 15 cts. oz. 40 cts.

ANCHUSA (Alkanet). HP. Italica, Dropmore. Blue; flowers in abundance all summer. Pkt. 15 cts. ANTIRRHINUM. See Snapdragon, page 33 .

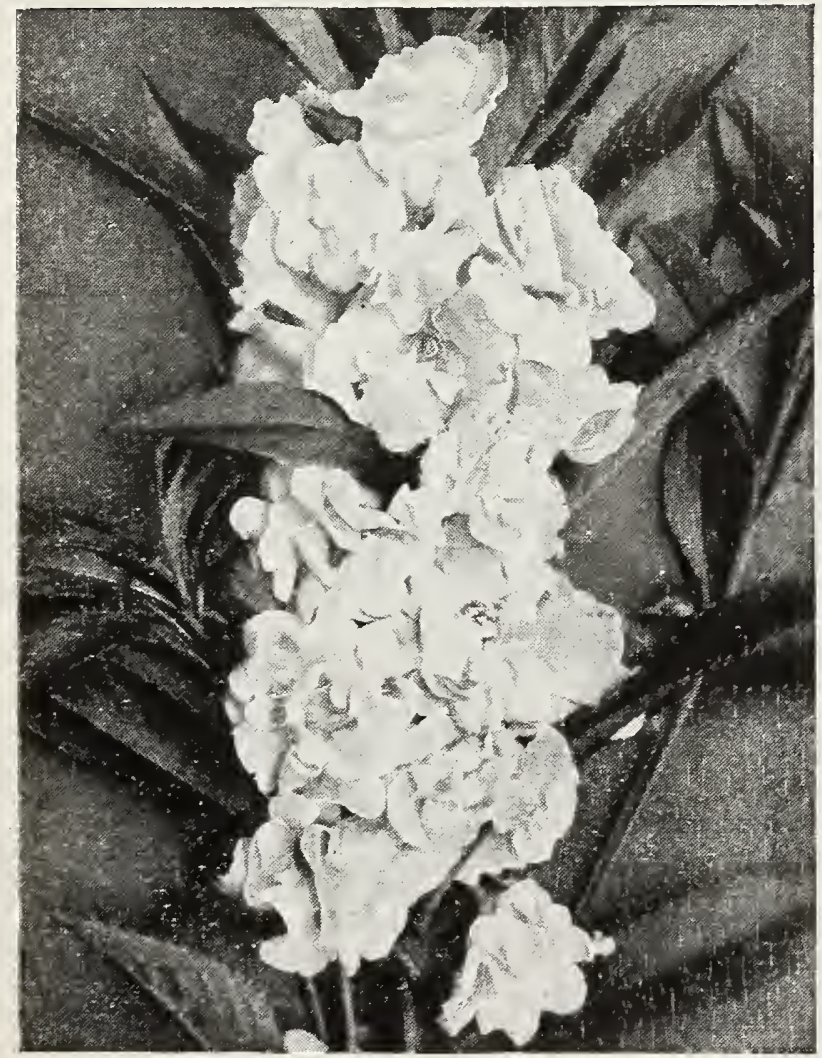

Balsam (Iady Slipper), an old farorite in grandmother's garden. Don't you remember?

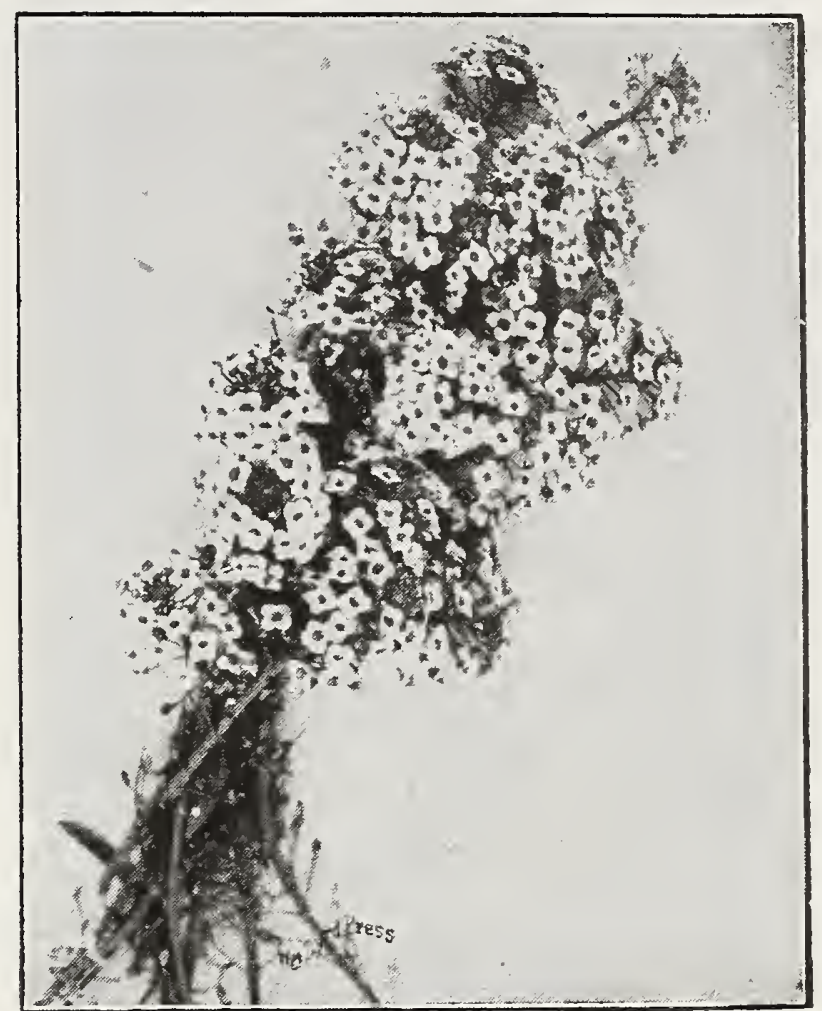

Can you fancy a garden without a border of Alyssum?

\section{Aquilegia}

(Columbine). HP. Hardy perennial easily grown from seed sown in the open ground either plants will often bloom the same season) or in August or September. No other plant has so airy a grace or is more generous of its blocms or better adapted for cutting. Blooms in May June, and July. A bed of the Long Spurred Hybrids, edging a bit of woodland or shrubbery. is one of the loveliest sights imaginable-like a bed of butterfiles.

Iong Spurred Hybrids (IMrs. Scott Elliott's Strain). A very excellent mixture of Columbines, comprising new and pleasing colors and combinations; effective and striking. Many shades of lavender, blue, white, yellow, scarlet and rosepink, all having long spurs. Pkt. 25 cts.

Iong Spurred Fybrids. An excellent mixture containing many colors and shades, the individual flowers having long spurs. Pkt. $15 \mathrm{cts}$

Mrixed Colors, Double. Pkt. $10 \mathrm{cts}$; 1/8 oz. 50 cts. Mixed Colors, Single. Pl.t. 10 cts.; $1 / 8$ oz. 25 cts.

\section{Arctotis grandis}

(Blue-eyed African Daisy). HA This lovely and unusual annua delights in a sunny location. 'The long-stemmed daisy-like flowers are pure white, the under sides of the petals lavender, and the centres lovely, soft gray blue; silvery foliage. Wonderful in blue and white border or with soft pale yellows. Blooms from early July till frost, and is valuable for cutting, lasting a week or ten days in the house. 2 to $3 \mathrm{ft}$. Pkt. $10 \mathrm{cts} . ; 1 / 4 \mathrm{oz} .60 \mathrm{cts}$

\section{Asparagus}

Easily raised from seed sown in early spring in heat. Valuable for bouquets and a nice plant for conservatory.

Plumosus nanus. The dwarf variety largely used by florists.

sprengeri. Fine for basketwork and for use with cut-flowers.

Price either sort: Pkt. of 10 seeds, 15 cts.: 100 seeds, $\$ 1.00$

AstrzR. See page 21.

BABY'S BREATH. See Gypsophila, page 28

My Zinnias from your seed are simply beautiful and are being greatly admired.

H. T. W., Hewitt, N. J., Aug. 5, 1924. 


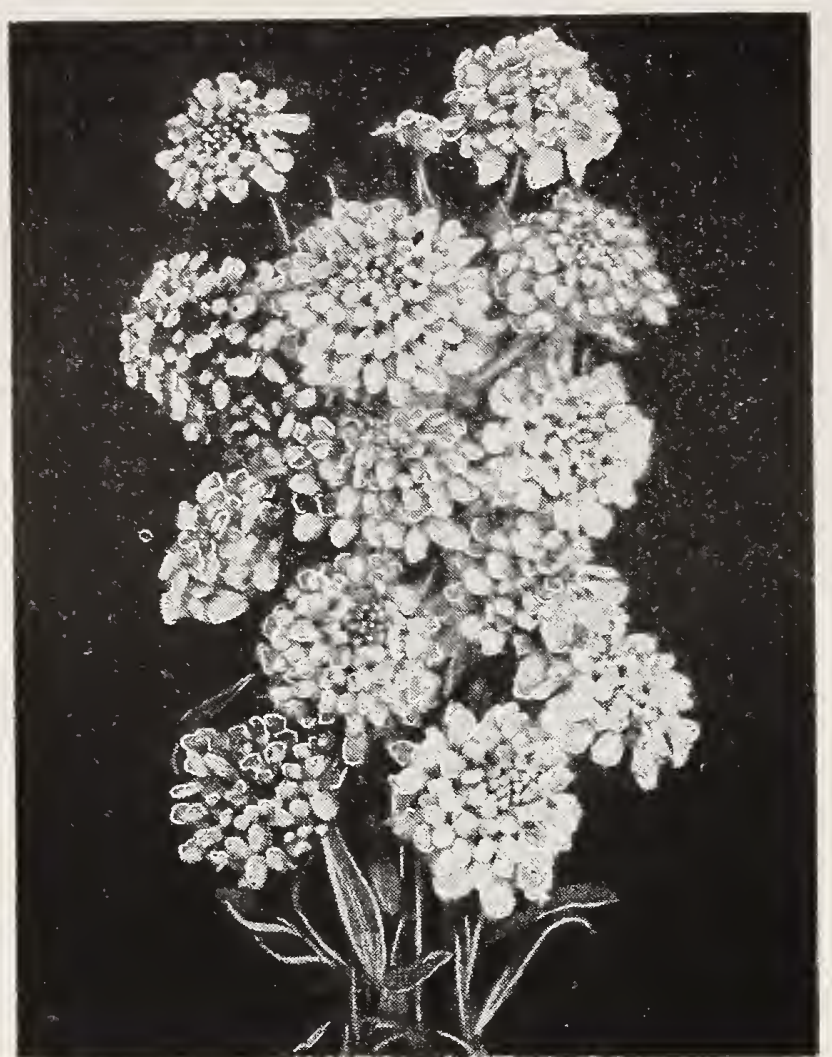

The pure clear white favorite Candytuft.

(Lady Slipper). HA. Double CamelBalsan lia-Flowered. An old favorite, of soil, and plenty of water. Seed sown in the open ground in May soon produces handsome bushes $11 / 2$ feet high with large roselike flowers nestling among the leaves close to the stems. Transplanting twice or thrice tends to dwarf plants into better shape. In transplanting, allow 12 to 18 inches each way. Blooms all summer.

Rose. Pkt. 10 cts.; $1 / 4$ oz. 40 cts.

Scarlet. Pkt. 10 cts.; $1 / 4$ oz. 40 cts

Royal Purple. Pkt. $10 \mathrm{cts}$; $1 / 4$ oz. $40 \mathrm{cts}$.

White. Pkt. 10 cts.; $1 / 4$ oz. 40 cts.

Collection one packet each of the above four colors for 35 cts.

Finest Mired Balsams. Pkt. 10 cts.; 1/4 oz. $30 \mathrm{cts}$. BATSAMI APPLI. See Momordica, page 30 .

Batsam PEAR. See Momordica, page 30.

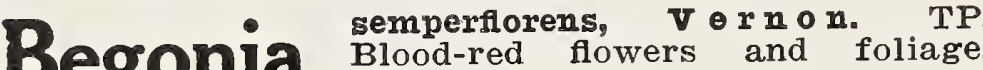 SgOLIa Pkt. $15 \mathrm{cts}$.}

\section{Bellis Perennis}

(Double English Daisy). HP1. The favorite little pink or white perennial "Button Daisy," hardy if mulched over winter, though new plants each year from seed give best results. Flowers in autumn if sown in spring.

White, Snowball. Pkt. $10 \mathrm{cts}$.

Pink, Iongfellow. Pkt. $10 \mathrm{cts}$

Míed. Finest. Pkt. $10 \mathrm{cts}$

Clar (Pot of Gold; Scotch Marigold) Calendula HA. A bed of Calendula is one of the bright spots of the one of the bright spots of the raised, flower quickly from seed, and will bloom without interruption until cut down by hard frost. Sow them where they are wanted to grow, 2 to 3 seeds together, at intervals of 12 inches, pull out the weakest ones, and leave but one plant to grow, or start the seed in the hotbed in March or April and transplant outdoors in May. 12 inches.

The Ball (New). Bright glowing orange, uniform$1 y$ double, grows upright on long stiff stems. Fine for outdoor culture or for forring. Plxt, $25 \mathrm{cts}$.; $1 / 8$ oz. $50 \mathrm{cts}$; $1 / 4$ oz. $85 \mathrm{cts} ; 0$ oz. $\$ 3.00$

Orange Ring. Rich dark orange. Pkt. $10 \mathrm{cts}$; $1 / 4$ oz. 30 cts.; oz. $75 \mathrm{cts}$ Lemon Queen, or Sulphur Yellow. Pkt. 10 cts.; 1/4 oz. 20 cts.; oz. 50 cts. Mixed, Officinalis fl.-pl. From named Not the common mixed.

Pkt. 10 cts.; $1 / 4$ oz. 20 cts.; oz. 50 cts.

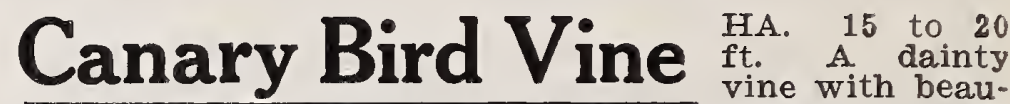
tiful cut leaves and pretty delicate flowers of a clear canaryyellow. Does well in the shade. Continuous bloomer. Plkt. $10 \mathrm{cts}$.; 1/4 oz. 15 cts.; oz. $45 \mathrm{cts}$.

\section{Candytuft}

A very hardy, easily grown little annual that blooms all the summer. It is a universal favorite for beds and masses. Successive sowings should be made during the sum. mer (sow in July for fall flowers) while the last sowing in the autumn will produce flowers early in spring. One foot high.

White Giant Hyacinth-flowered. Extra fine. Pkt. 10 cts.; $1 / 4$ oz. 30 cts.; oz. $\$ 1.00$.

Carmine. Bright carmine-rose. Pkt. 10 cts.; $1 / 60 z$. 25 cts.

Crimson. Rich, deep shade. Pkt. 10 cts.; $1 / 4$ oz. 25 cts.

Flesh Pink. Very popular shade. Pkt. 10 cts.: $1 / 4$ oz. $25 \mathrm{cts}$.

Inllac. Delicate shade. Pkt. $10 \mathrm{cts}$; 1/4 0z. $25 \mathrm{cts}$.

Mixed Colors. Pkt. 5 cts.; 1/4 oz. 20 cts.; oz. $50 \mathrm{c}$.

Perennial Candytuft (Iberis). HP.

Illac (Gibraltarica). Very large flowers.

Pkt. 15 cts.

White (I. sempervirens). For rockeries, etc. Pkt. 25 cts.

\section{Cardinal Climber F i e r y cardina. flowers about $11 / 2$
inches in diame.}

ter. Dark green laciniated leaves.

Pkt. of 15 seeds, 10 cts.

Calliopsis HA. Showy, free-fowering on Calliopsis nuals of ciear yellows and ritch red-maroons and browns, of any sunny position, blooming all summer. Give plenty of room between plants.

Crimson King. Large crimson flowers. 1 foot. Pkt. $10 \mathrm{cts}$.

Golden Wave (C. Drummondii). 1 foot. Flowers yellow with a rich crimson circle around the eyes. Pkt. 10 cts.

Mixed, Single, Tall. Very choice. 2 feet.

Pkt. 5 cts.; 1/4 Oz, 25 cts.

See also Coreopsis (Perennial), page 26.

Campanula Rich in color and protuse Campanula a they flower most profusely. perennials will bloom early the next year.

\section{Biennial Varieties}

Thrive best' in light, rich soil. Some of the varieies flower the first season if sown early.

Blue (C. Carpatica; Carpathian Harebell). Blooms all season; fine for edging; 6 inches. Pkt. 15 ctr.

White (C. Carpatica alba). Pkt. 15 cts.

\section{Perennial Varieties}

Mealum (Single Canterbury Bells). The old-fashioned sort, with beautiful, large, bell-shaped blossoms.

Blue, Rose, White and Irixed Colors. Each 10 cts. per pkt.

Calycanthema (Cup-and-Saucer; Canterbury Bells). The finest type. cts. per pkt. C. about twelve weeks from time of sowing. Large, double, highly scented flowers on long stems. With slight protection they will survive ordinary slight pro

Crimson, White and Mixed Colors. Each 10 cts. per pkt.

CASTOR-OIT BEAN. See Ricinus, page 32.

CrIosta. See Cockscomb, page 26, and Chinese Woolfiower, page 25 . 


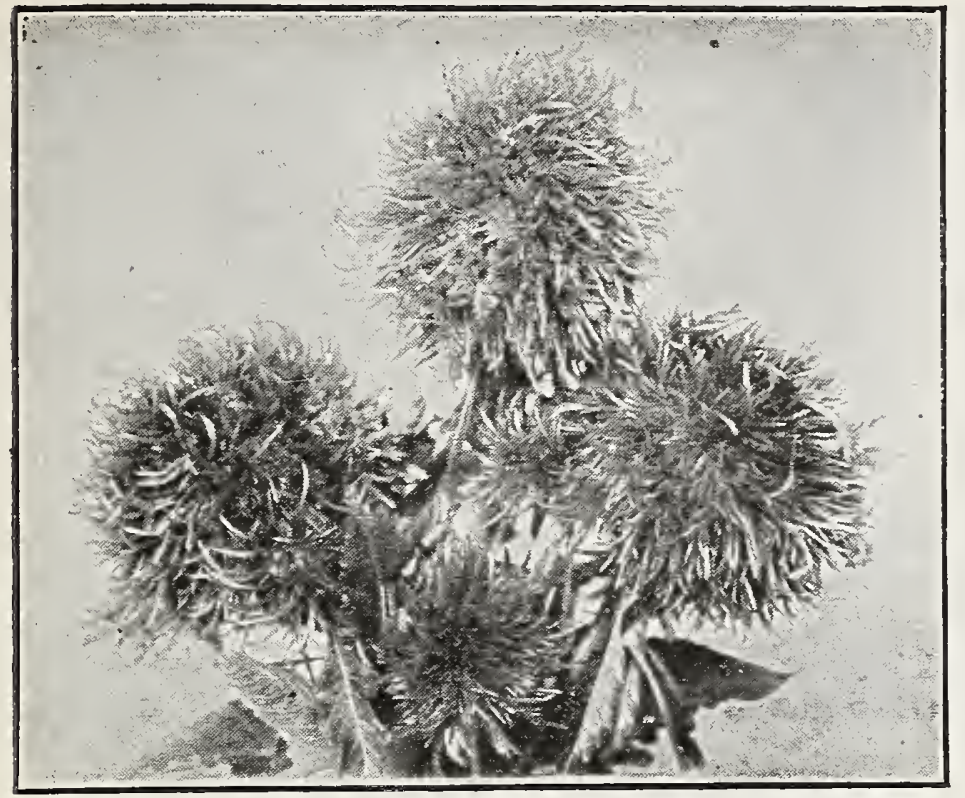

The curiously fascinating Chinese Woolflower, almost like a ball of wool.

\section{Centaurea or Cornflower}

Sow early in spring. Blooms steadily from early summer till frost if kept from seeding; even then will self seed for future seasons. One of the truest blues in the garden; grows and blooms anywhere, and is excellent for cutting. A cluster of the blue sorts combined with yellow Calliopsis, Marigolds, Calendulas, make a beautiful combination.

Also cailed Ragged Sailor, Kaiser Blumen, etc.

We have discarded the old common single Cornflowers. The strain of double we offer cannot be excelled.

\section{Double Cornflower \\ (Centaurea cyanus). HA.}

These popular annuals are also known as Bachelor's Buttons, Blue Bottle, Ragged Sailor, etc.

Dark Blue. Pkt. $10 \mathrm{cts}$; $1 / 4 \mathrm{oz} .35 \mathrm{cts}$.

Rose. Pht. 10 cts.; $1 / 4$ oz. 35 cts.

White. Pkt. 10 cts.; 1/4 oz. 35 cts.

Mixed Colors. Pkt. 10 cts.; 1/4 oz. 25 cts.; oz. 75 c.

\section{Various Centaureas H.A.}

Rosf Iavender (C. Americana; Basket Flower) A splendid variety growing 3 feet high and bearing immense blooms. Pkt. 10 cts.

Dusty Millex (C. gymnocarpa). Finely cut silvery-gray foliage. Fine bedders. 1 foot Pkt. 10 cts.

White (C. candidissima; Dusty Miller). For beds, hanging-baskets, pots, etc. Pkt. 10 cts.

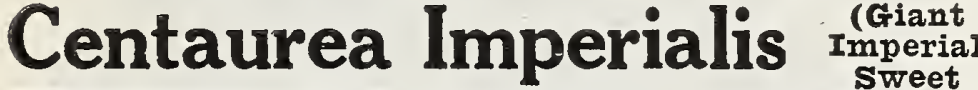

These are wonderful for cutting-long-stemmed, exquisitely fringed, most graceful in appear ance, and delightfully fragrant. The most beautiful colors are found among them. Easy to grow, flowering freely from June until frost For fine flowers, successive sowings should be made two weeks apart during May and June. They do well in a rich, loose soil and will amply repay you for any trouble you go to in the preparation of the bed. Cover seeds 1/4 inch. 2 to 3 feet.

Marguerite. Pure white

Graziosa. Lilac.

Favorite. Brilliant rose.

Splendens. Rich purple.

All pkt. 10c:

Mixed Colors.

$1 / 4$ oz. $40 \mathrm{cts}$

Collection: 1 pht each of the 4 sorts for 35 cts.

\section{Chinese Woolflower}

$C$ los 1 a Childsil). $\mathrm{T}$ h e flowers

ball of wool. The plants will average 2 feet in height. They branch freely, and by mid-summer are covered with blooms. Bloom all during the fall and retain full beauty and color until severe frost. Besides being a most serviceable bedding flower it is well suited for cutting, lasting in water almost a week. Sow outdoors in April, and thin the plants to stand 8 inches apart.

Crimson. Handsome balls of rich crimson. Magnificent. Pkt. 15 cts.; 2 pkts. for 25 cts.

Pink. This is a delicate, yet rich shade. Pkt. 15 cts.; 2 pkts. for 25 cts.

Yellow. A rich shade that blends well with the other two. Pkt. 15 cts.; 2 pkts. for 25 cts.

1 pkt. each of the 3 colors for $40 \mathrm{cts}$

Mixed Colors. Pkt. 15 cts.; 2 for $25 \mathrm{cts}$

\section{Chrysanthemum H.A.}

Showy garden favorites, fine for cut-flowers. These hardy annuals are summer-flowering border plants, quite distinct from the hardy perennial and autumn-flowering sorts:

IIorning star. Sulphtir-yellow, very pretty. Pkt: 10 cts.; 1/4 oz. 25 cts.

Evening Star (C. segetum; Golden Marguerite) Pure golden yellow flowers, 3 inches across. Pkt. 10 cts. 1/4 oz. 25 cts.

Double. Mixed, Coronarium. Pkt, 10 cts.; $1 / 4$ oz 25 cts.

Yellow, Double. Rich color. Pkt. 10 ets.

White, Double. Fine. Pkt. 10 cts.

Mixed, Single (Tricolor). Pkt. 5 cts.; 1/4 ez. 20 cts. CINERARIA. TP. One of the most useful and ornamental greenhouse plants.

Mixed Grandiflora Prize. Pkt. 50 cts.

silverfoliage (C. maritima candidissima). (Dusty Miller.) HHP. Pkt. 10 cts.

C HA. Does well in sun or shade 2112 grows 2 to $2 \frac{1}{2} \mathrm{ft}$. high, with leafy racemes of double flowers. Splen-

Pure White (C. elegans alba). Pkt. 10 cts. Salmon Queen. Salmon-pink. Pkt, 10 cts. Scarlet Queen. Splendid. Pkt. $10 \mathrm{cts}$. Purple King. Light purple. Pkt, $10 \mathrm{cts}$. Mixed, Double. New shades. Pkt. $10 \mathrm{cts}$

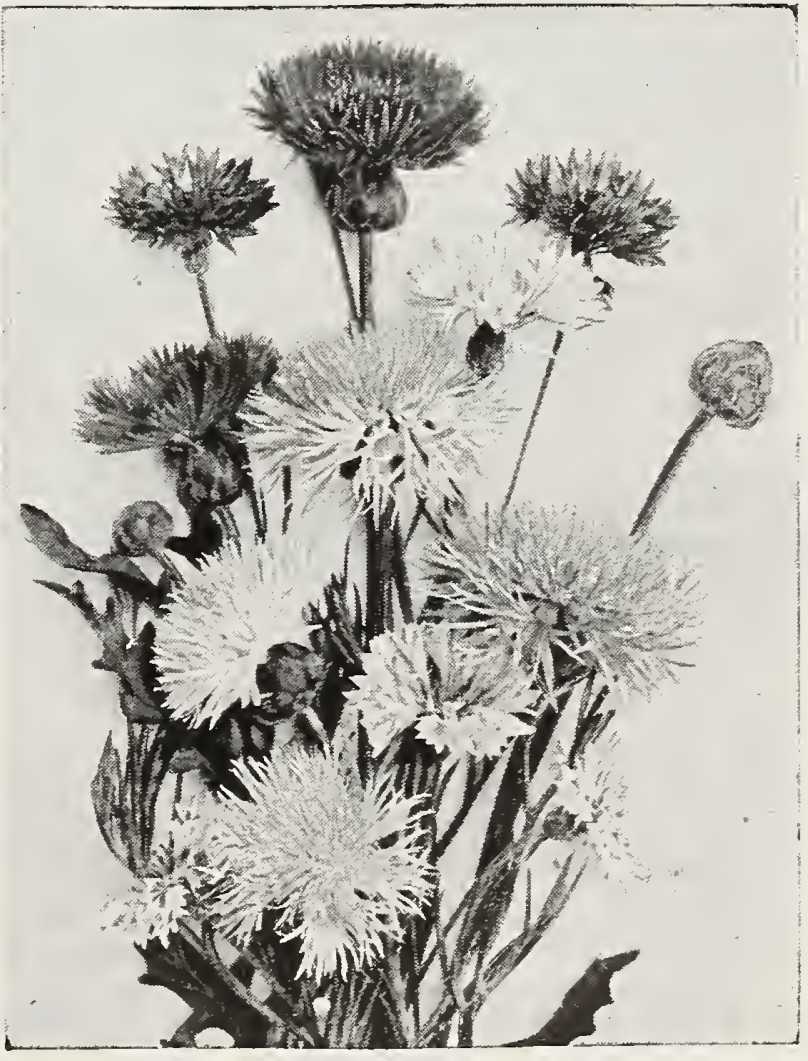

Imperial Sweet Sultans-Fraglle but long lasting fragrant and altogether charming. 


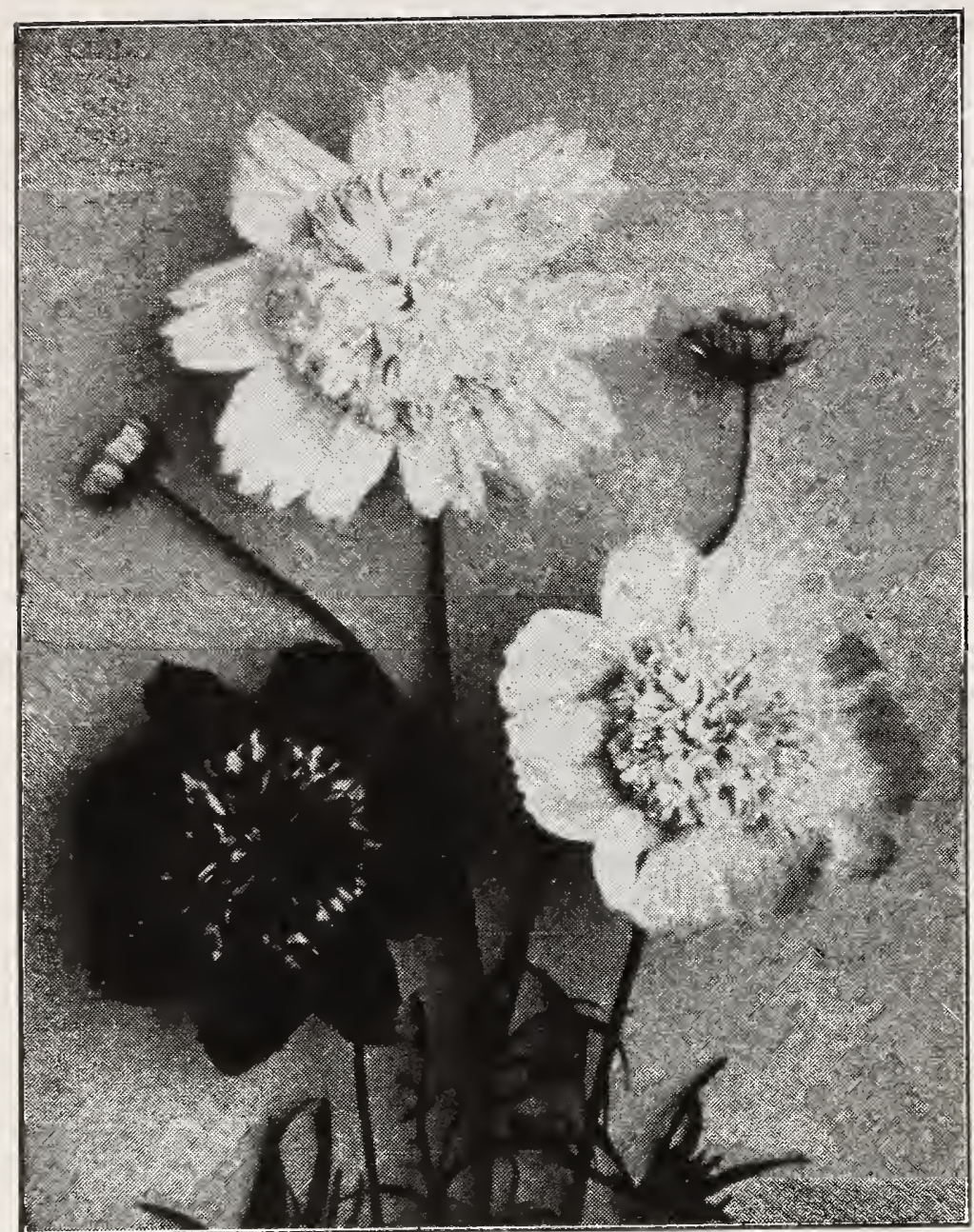

Crested Cosmos.

Cosmos, essential in every garden for cut flowers, late in the season when others have gone.

Cockscomb IC 10 sia cristata) HA. HA. Free - blooming a n n a l $\mathbf{n}$, growing best in rather light plenty of moisture and blooming all summer. Our seed produces large combs.

Glasgow Prize. Dark crimson. Extra fine Pkt. 25 cts.

Empress. Dwarf red. Pkt. 15 cts.

Dwaxf IIixed. Extra. Pkt. 10 cts.

\section{Feathered Cockscombs}

(Celosis plumosa). IA.

Make fine plants for large beds or groups; the plumes can be cut and dried for winter bouquets.

Triumph of the Exposition. Crimson. $3 \mathrm{ft}$. Pkt. 10 cts.; 1/8 oz. 50 cts.

Thompsoni magnifica, Mixed.

Pkt. 10 cts.; $1 / 8$ oz. 50 cts

Pride of Castle Gould. All shades of yellow and rose to crimson. Splendid.

Pkt. 25 cts.; $1 / 8$ oz. $\$ 1.00$.

Childsii. See Chinese Woolflower, page 25.

C HA. Produces thousands of beautiConnos ful flowers in white, pink and crimson shades in autumn when other flowers are scarce. When about a foot high pinch tops to induce bushy growth. They prefer a rather light, not too rich, soil. but do well almost anywhere. About $6 \mathrm{ft}$.

\section{WIISON'S GIANT-FIOWERED.}

Iady Ienox. Pink. Pkt. 5 cts.; 1/4 oz. 25 cts. Iady Inenox. White Pkt. 5 cts. 1/4 oz. 25 cts. Perfection, Crimson. Pkt. 5 cts.; $1 / 4$ oz. 25 cts. Perfection, Mixed. Pkt. 5 cts.; $1 / 4$ oz. $20 \mathrm{c} ;$ oz. $50 \mathrm{c}$. see also next column.

Tor a perfect lawn sow

WIISON'S EVERGREFN IAWN SEED. See Page 3

How to make a lawn, see inside front cover.

\section{WILSOIN'S EXTRA-EARIY COSMOS.}

Flowers in July.

Crimson. Pkt. 5 cts.; 1/4 oz. 25 cts.; oz. 75 cts. White. Pkt. 5 cts.; $1 / 4$ oz. 25 cts.; oz. 75 cts.

Pink. Pkt. 5 cts.; $1 / 4$ oz 25 cts.; oz. 75 cts.

NEW EXTRA-EARLY DOUBLE-CRESTED COSMOS

The flowers are of good size, with fully double centers and an outer row or crest of broad raypetals. This is the best of all Cosmos for cutflowers. Produces a large number of doubles.

Whirlwind White. Splendid. Pkt. $25 \mathrm{cts}$.

Peach Blossom Pink. Exquisite. Pkt. 25 cts.

Carnelia Crimson. Brilliant shade. Pkt. $25 \mathrm{cts}$.

Mixed Colors. Pkt. 25 cts.

ConvorvUrus. See Morning-Glory, page 30, and Ipomoea, page 29.

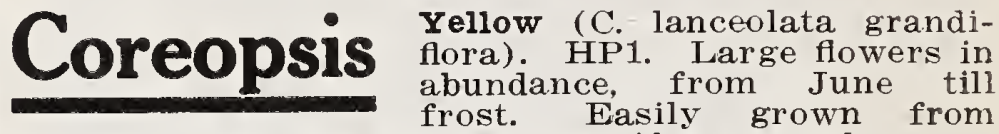
seed, flowering the first year if sown early.

Pkt. $10 \mathrm{cts}$; 1/8 oz. 20 cts.; 1/4 oz. 35 cts.; oz. $\$ 1$. CYPRESS VINE. See page 29. Ipomoea Quamoclit.

\section{Climbing Vines from Seed}

Climbing vines are very useful in camouflag ing some fence or telegraph pole or pile of rocks, with their attractive foliage or brilliant display of color, transforming them into beautiful spots. The hardy kinds such as Morning Glories, Ipomoea, etc., may be planted early in the spring, but the more tender climbers such as Canary Bird Vine, Dolichos, Gourds, etc. should not be planted until May.

Canary Bird vine ................ see page 24 Cardinal Climber ................... Cobaea scandens .................. see below polichos Dolichos $\ldots \ldots \ldots \ldots \ldots \ldots \ldots \ldots \ldots \ldots$ see page 28 Gourds $\ldots \ldots \ldots \ldots \ldots \ldots$ see page 28

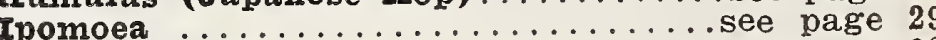
Mrorning Glory ..................... see page 30 Momordica Pueraria (Kudzu vine).............. see page 32

$\begin{array}{rllll}\text { Mrixed Annual Climbers. } & \\ \text { Pkt. } 10 & \text { cts.; } 1 / 4 & \text { oz. } 25 & \text { cts.; oz. } 75 & \text { cts. }\end{array}$

\section{Cobaea scandens HA. Fine}

Puxple. Bell-shaped flowers. $15 \mathrm{ft}$. Pkt. $10 \mathrm{cts}$ white. Same as above. Pkt. 10 cts.

\section{Cut-Flower Garden}

\section{Mixture see page 20.}

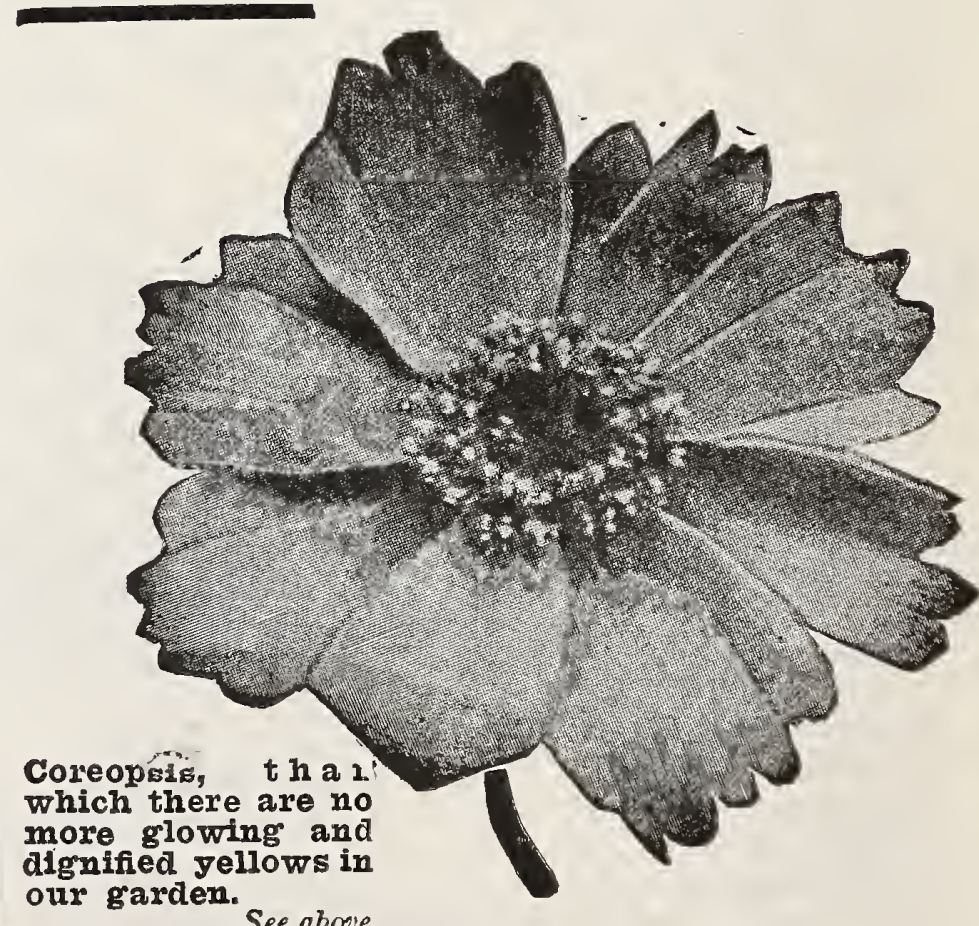


Dalias (From seed). HHP.1. Grown anlas very readily from seed and flowering the first season. It Dahlias bloom they turn the little afternoon garden tea party into "a regal reception." Just now they are enjoying an exceptional era of popularity. Why not start some new kinds from seed and thus secure the finest of blooms together with the joy of achievement and of unexpected results? From a single packet of seed you may obtain a seedling worth its weight in gold. Order today lest you forget.

Wilson's New Giant Mixed. A wonderful new selection producing Giant double and semidouble flowers of unusual grace and beauty. Takes in all the best types and colorings in existence. Don't fail to give it a trial.

Liberal pkt. \$1.00; smaller pkt. 50 cts.

Cactus-flowered, Extra Fine Mixed. Very fine. Pkt. 25 cts.

Paeony-flowered, Extra Fine Mixed. The very best strain obtainable. Pkt. $50 \mathrm{cts}$.

Double Mixed, Extra Fine. A splendid strain. Well worth trying. Pkt. 25 cts.

Giant Perfection, Finest Mixed Single. From selected flowers. Pkt. 15 cts.

For Bulbs of Named Varieties, see back cover. If you haven't tried Wilson's Dahlia Fertilizer, do it this year. See back cover.

DATURA WRIGHTII (Angel's Trumpet). HHA. White and lilac; sweet-scented; 3 feet. Pkt. $10 \mathrm{cts}$.

\section{Delphinium}

(Perennial Larkspur). HP.1. In variety and beauty o its blue tints, the Delphinium has no equal. Som species flower early and late; the season for all can be prolonged by cutting away withered flower-stems. All are easily cultivated. Blooms are finest in soil deeply dug and well enriched with old manure. They must have room to grow; 3 feet each way is not too much for the taller sorts. If sown in fall or very early spring nearly all will bloom the first season.

WIISON'S GOID MEDAI HYBRIDS MIXED. Splendid strain of vigorous habit. Immense spikes in all the varying shades of blue with iridescent colorings and markings making them lmost irradiant in their splendor.

Pkt. 25 cts.; $1 / 8$ oz. $\$ 1.00$

Blue Butterfly. (D. Chinense.) Lovely salvia blue shade. Distinct. Ht. 18 in. Pkt. 10 cts. white. (D. chinense). Fine. Pkt. 10 cts. See also next column.

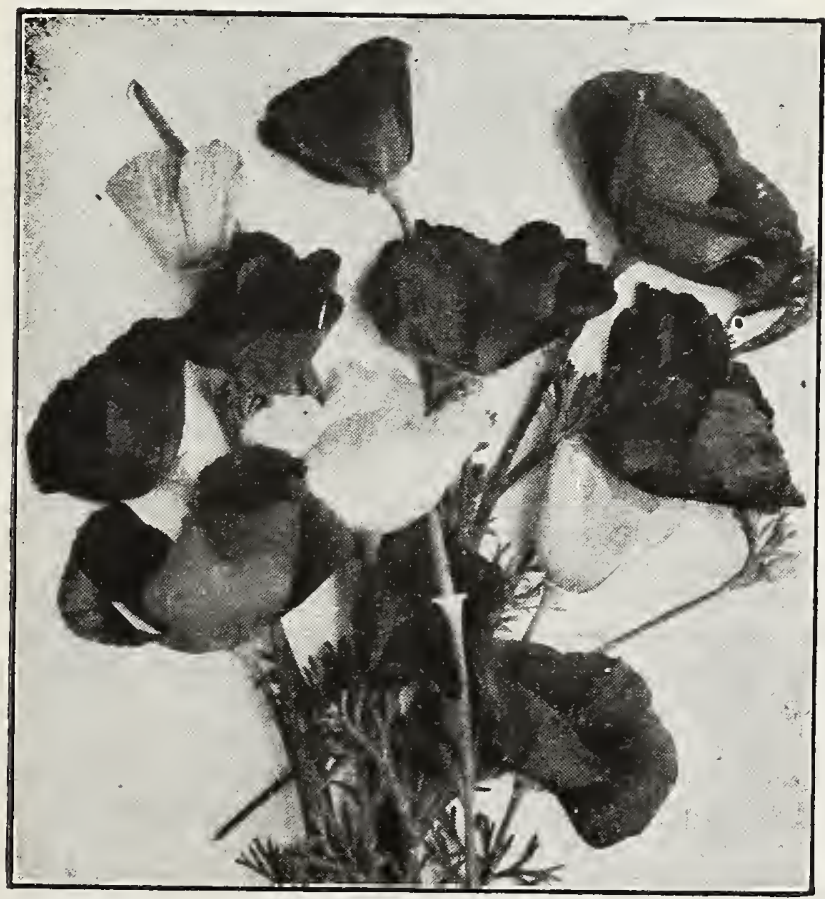

Fschscholtzia. How joyously the dainty California Poppies dance together in their gaudy gowns with lacy green trimmings!

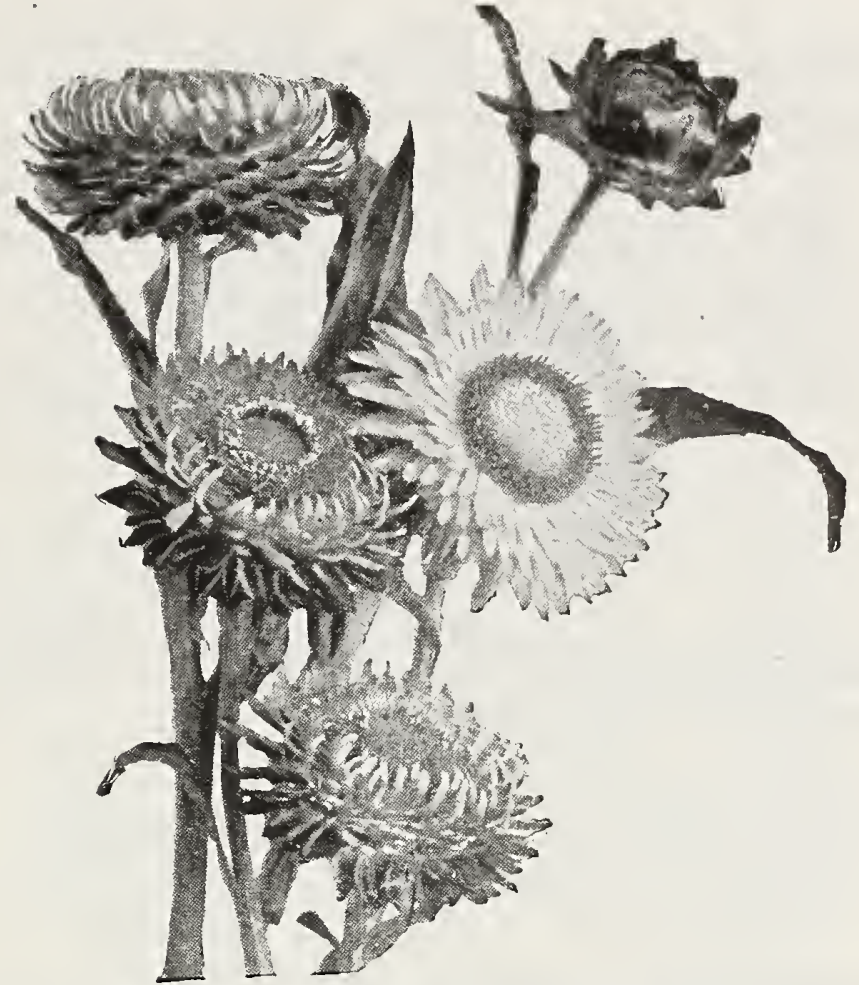

Helichrysum, the Flower Eternal (Bverlasting) See next page.

\section{DELPHINIUM - Continued}

Pale Blue (D. Belladonna). Lovely shade. Majestic plant; 4 feet tall. Pkt. 25 cts.

Dark Blue (Bellamosum). Belladonna type but dark blue. Pkt. 25 ets.

Belladonna Hybrids. All shades of blue in dazzling profusion. Pkt. 25 cts.

Blue, White Center (D. formosum). 3 feet. Pkt. 25 cts.

For ANNUAI IARKSPUR, see page 29.

Didiscus coeruleus

B 1 u e L a c e Flower). HA Long stemmed lavender blue flowers. Constant bloomer. Height 3 feet. soed requires 3 to 4 weeks to germinate. Plant in partial shade. Pkt. 15 cts.

\section{Dimorphotheca}

(African G o l d e $\mathbf{n}$ Daisy). HA. Beautiful. The flowers vary in color from white to salmon, many being zoned with several colors around the black disk. Easily grown in a sunny place.

Orange-Yellow (D. aurantiaca). Fine. Pkt. 10 cts mixed (D. aurantiaca hybrida). Pkt. 10 cts.

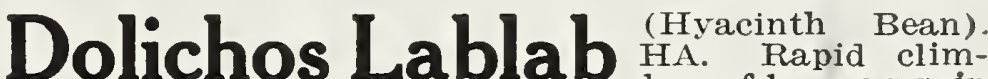 ber; f $10 \mathrm{w}$ e $\mathrm{r}$ s in clusters. 10 feet}

White, Purple, Mixed. Fach, pkt. 5 cts. $1 / 4$ oz. 15 cts.; oz. 40 cts.

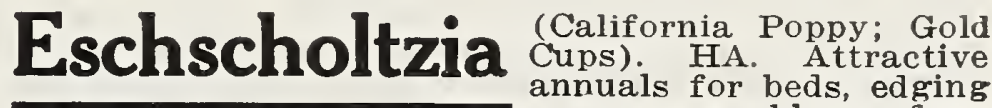
or masses; bloom from June to frost. Sow seed where plants are to remain. 1 foot.

Fire Flame. Brilliant orange-scarlet. Pkt. 10 cts.

Orange $\mathbf{K i n g}$. Intense orange shading lighter toward margin of petals. Pkt. $10 \mathrm{cts}$.

Orange (E. californica). Pkt. 10 cts.; 1/4 oz. 25 cts. Carmine-Rose (Rose Cardinal). Pkt. 10 cts.

Iixed, Iarge Flowering. Not the common sind A select large flowering erect type. Choica Pkt. 10 cts.; $1 / 4$ oz. 35 cts.

EUPAORBIA. HA. For beds or borders; flowers inconspicuous; foliage exceedingly ornamental.

Variegata (Snow-on-the-Mountain). Foliage veined and margined white: 2 feet. Pkt. 10 cts 
Everlasting Flowers $\begin{gathered}\text { (straw } \\ \text { rlowers). }\end{gathered}$

Flowers of eternal beauty, those that never fade. Unsurpassed for winter decoration and when made into bouquets or arrayed in vases, they last for years. Should be cut and dried when in bud and blossom.

Felichrysum monstrosum, Double, Mixed. HA. Will grow in almost any soil. 2 feet. Pkt. 10 cts.; $1 / 4$ oz. 50 cts.

Globe Amaranth (Gomphrena). HA. Globe-shaped or clover-like flowers. Fine bedder. 2 feet. Flesh, Purple, White, Mixed. All 10 ets. pkt.; 30 cts. per $1 / 40 z$

Xeranthemum. HA. Mixed. Very fine. Silvery foliage and double, silky flowers. Pkt. $10 \mathrm{cts}$.

Forget-Me-Not sown from spring till midsummer. Alpestris sorts bloom in April; Palustris not till May. Alpestris, Blue. Fine. Pkt. $10 \mathrm{cts}$.

Alpestris, Mixed. Very choice. Pkt, $10 \mathrm{cts}$.

Palustris semperfiorens. HP. Blue. True ForgetMe-Not. 9 inches. Pkt. 25 cts.; $1 / 8$ oz. 75 cts.

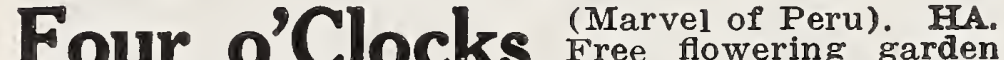 favorite. 2 feet.}

Mised Colors. Pkt. 5 cts.; 1/4 oz. 15 cts.; oz. 40 cts.

\section{Foxglove}

(Digitalis). HP. $H$ a $n d s o m e$ stately hardy plants, succeeding under almost all conditions, and Does well in half-shade. 3 to 5 feet.

cloxiniaeflora. Mixed Colors. Handsome, spotted, gloxinia-like flowers on long spikes.

Pkt. 10 cts.; $1 / 4$ oz. 40 cts.

C ำ a showy flowers. Blooms profusely from early summer borders, or for cutting. Sow where they are to bloom. $11 / 2 \mathrm{ft}$.

Single Irixed Picta. Fine colors. Pkt. 10 cts.; $1 / 4$ oz. 25 cts.

Double Mixed Iorenziana. Profuse-flowering strain; beautiful colors. Pkt. 10 cts.; 1/4 oz. $25 \mathrm{c}$.

Gaillardia grandiflora HP. Thrives almost anywhere, requires 1 it t l e ng in July ting. 2 feet.

The Dazzler (New). A splendid new variety of striking beauty and effectiveness. The color is rich dark orange, with deep crimson center. Pikt. 25 cts.; $1 / 8$ oz. $\$ 1.00$.

rinest IMixed. Newest perennial sorts. Pkt. 10 cts.; $1 / 8$ oz. 30 cts.

Godetia The plants bloom profusely and
bear showy flowers of satiny tex-
ture. Does best in rather poor soil and in somewhat shaded situations. 1 foot Dake of York. Scarlet; compact. Pkt. 10 cts. Pure White (Duchess of Albany). Pkt. 10 cts. Blood Red (Lord Roberts). Brilliant. Pkt. 10 cts Rose (Lady Satin Rose). Beautiful. Pkt. 10 cts. Mised from above named sorts. Pkt. 10 cts.

COTRDS, ORNANTRTAI. HA. Quick-growing vines; curious shapes; useful house ornaments. Finest Mixed. Plst. $10 \mathrm{cts}$; $1 / 4 \mathrm{oz} .20 \mathrm{cts}$; oz. $50 \mathrm{c}$.

\section{Gypsophila}

(Baby's Breath). Free-flowring. Of easiest culture; indispensable for cut-flowers. Should be in every garden. legans alba grandifora HA. Large-flowering, pure white. Our own special strain. Very superior. Pkt'. 10 cts.; 1/4 oz. 25 cts.; oz. 75 cts. Elegans rosea. Lovely rose. Pkt. 10 cts.; 1/4 oz. 35 cts.: oz. $\$ 1.00$.

Panicalata. HP1. White; fine; a favorite hardy perennial; 2 feet. Pkt. $10 \mathrm{cts}$ Helichrysum $\underset{\substack{\text { See } \\ \text { abovererlasting Flowers, }}}{\text { and }}$

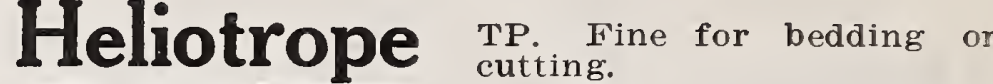

Regale or Regal. Dwarf, compact; large flowers Pkt. 25 cts.

Finest Mixed Iarge-flowering. $2 \mathrm{ft}$. Pkt. 10 cts.

\section{Haphazard Flower}

\section{Garden Seed see page 20.}

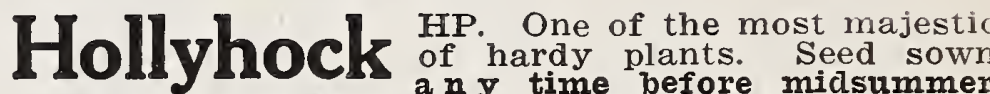
a $\mathrm{n}$ time before midsummer will produce fine flowering

plants the next year.

Double Varieties-Chater's Prize Strain

Black, Pink, White, Yellow, Crimson. Each, pkt 10 cts.

Collection: One plst. each of above 5 colors, 40 cts.

Double Mixed. Pkt. 10 cts.

IUMUIUS (Japanese Hop). HA. Rapid climber Fine for verandas, trellis, etc. Should be better known; so easily grown. 12 feet.

Japorica. Green foliage. Pkt. $10 \mathrm{cts}$

Japonica variegata. Green and white. Pkt. 10 cts

Hunnemannia HA. (santa Barbara

Fumarlaefolia. Bushy plants about 2 feet high, with striking, feathery, grayish foliage. Plants from seed sown early in May will bloom continuously from mid-July until frost The best of all Poppies for cutting, the buttercup-yellow. of all Poppies for cutting, the buttercup-yellow, stems, keeping in good condition for severa days. Pkt. 10 cts.; 1/4 oz. 25 cts.

HYACINTH BEAN. See Dolichos, page 27.

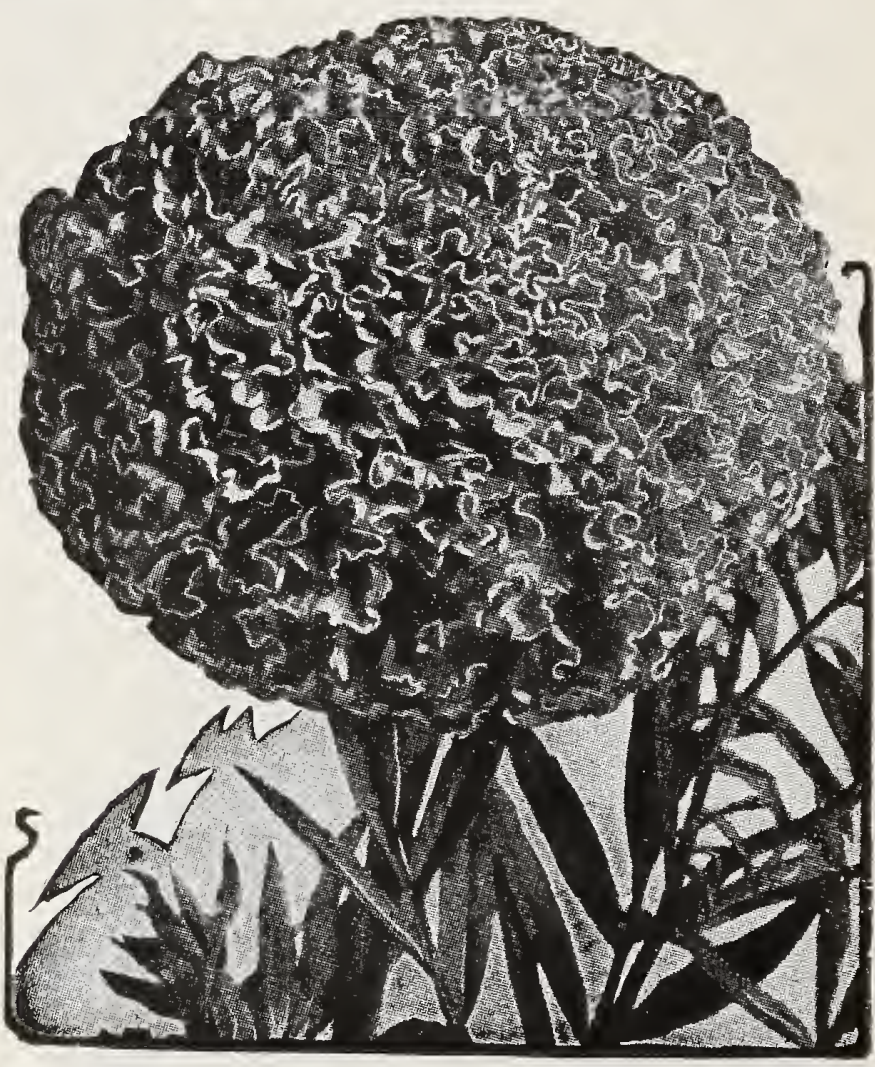

The Giant Double Marigold, its blossoms bursting with their load of golden petals, seems to have focused the sunshine in their glowing hearts. Sef pages 29 and 30 .

Sow Wilson's Irvergreen Irawn Seed-Best of all. See page 3 .

FIOWRRS FOR SHADY AND PARTIY SHADFD PIACFS

Achillea, Balsams, Begonia, Bellis, Campanula, Columbine, Coreopsis, Foxglove, L o b e 1 i a Myosotis (Forget-me-not), Pans y, Poppy (Perennial). 
Ipomoea

HA. Climbers of rapid growth, with beautiful and varied flowers; for covering walls, trellises arbors, etc. Soak seed in warm water over night to assist germination.

white (I. Mexicana alba grandiflora; Giant White Moonflower). Large, fragrant flowers, 5 to 6 inches in diameter; open at night and on dull days. Pkt. 10 cts.; 1/4 oz. 25 cts.

see also Morning Glory, page 30.

IPOMCA QUAMOCIIT (Cypress Vine). Fern-like foliage, star-shaped flowers. Sow in May. $15 \mathrm{ft}$ scarlet, white. Each, pkt. $5 \mathrm{cts}$.; 1/4 oz. $20 \mathrm{cts}$.

\section{Job's Tears}

(C o i $\mathrm{x}$ lacryma-Jobi)

most beautiful ornamental grass with great drooping sprays of hard bead-like seeds. These seeds are fine for various kinds of ornamental work and are strung and worn about the neck of teething babies who get much help and relief from chewing the beads.

Pkt. 5 cts.; $1 / 4$ oz. 15 cts.; oz. 40 cts.

\section{Kochia} tricophylla (Summer Cypress, or Mexican Fire Bush) midal; foliage green, turning to scarlet in the summer and brown in fall; 2 ft. Pkt. 10 cts.; 1/4 oz. 25 cts.

\section{Larkspur}

HA. (For hardy or perennial sorts see Delphinium, page 27.) The tall spikes of beautiful, ir ers, are especiall gular, often long-spurred fow f blue and the their charm. Especially desirable for bedding. Sow outdoors in early spring or fall; transplant $11 / 2$ feet apart.

ciant Stock-Flowered. 2 feet.

White, Iilac, Dark Blue, Sky Blue, Shell Pink, Carmine. Each, pkt. 10 cts.; 1/4 oz. 30 cts

rixed Giant Stock-flowered. Pkt. $10 \mathrm{cts}$.

Collection. 1 plit. each above 6 colors, 50 cts.

IAVATrRA (Mallow). HA. A beautiful annual, 2 feet high, bearing all summer, large, cupshaped flowers.

Pink (L. splendens grandiflora rosea). Pkt. 10 cts.

FA. Crandiflorum Rubrum (Crtmson 12UID Flax). $2 \mathrm{ft}$. One of the most brilliantly colored annuals; flowers glowing crimson-rose. Beautiful in beds and borders; may be had in bloom from May to October by successive sowings. Pkt. 10 cts. Grandiflorum Roseum. Delicately beautiful shade. Pkt. 10 cts.

Perenne. HP. Bright blue flowers; hardy. $11 / 2 \mathrm{ft}$ high. Pkt. 10 cts.

7 HHA. For edgings, urns and basLODela kets; requires rich soil and plenty of water.

Crystal Palace compacta. Deep blue; fine for car pet bedding: 4 inches. Pkt 25 cts.

Deep $\mathbf{3 l u e}$ (L. erinus gracilis). Trailing; 1 foot. Pkt. 10 cts.

\section{Love - in - a - Mist} Nigella). H A. Free flowering annuals of easiest

flowers and seed-pods. 1 to 2 feet.

Double Blue, Miss Jekyll. Pkt. 10 cts.

Double Mixed. Pkt, 10 cts.

\section{Lupinus} (Lupine). HA and HP. (Also called Ladies in Green.) Long, graceful spikes of richly colored, pea-shaped flowers; prefers a little shade. Splendid for cut-flowers. 2 feet

\section{Annual Sorts (Hartwegii)}

Sky-Blue, Rose, White. Fach, pkt. 10 cts.

Mixed. All colors. Pkt. 5 cts.; oz. 40 cts

\section{Perennial Lupinus}

Polyphyllus. Succeeds in any good soil; blooms in May and June.

Blue, White, Rose, Mixed. Each, pkt. 10 cts.

IYCHIIS. HP1. Handsome plants of easy culture; bloom the first year if sown early.

Scarlet (L. chalcedonica: Jerusalem Cross). $2 \mathrm{ft}$. Pkt. 10 cts.; 1/4 oz. 25 cts.

You do not HAVE to have a space purposely set aside for a :flower garden. Use flowers as borders in your vegetable garden or between the rows if you are cramped for room.

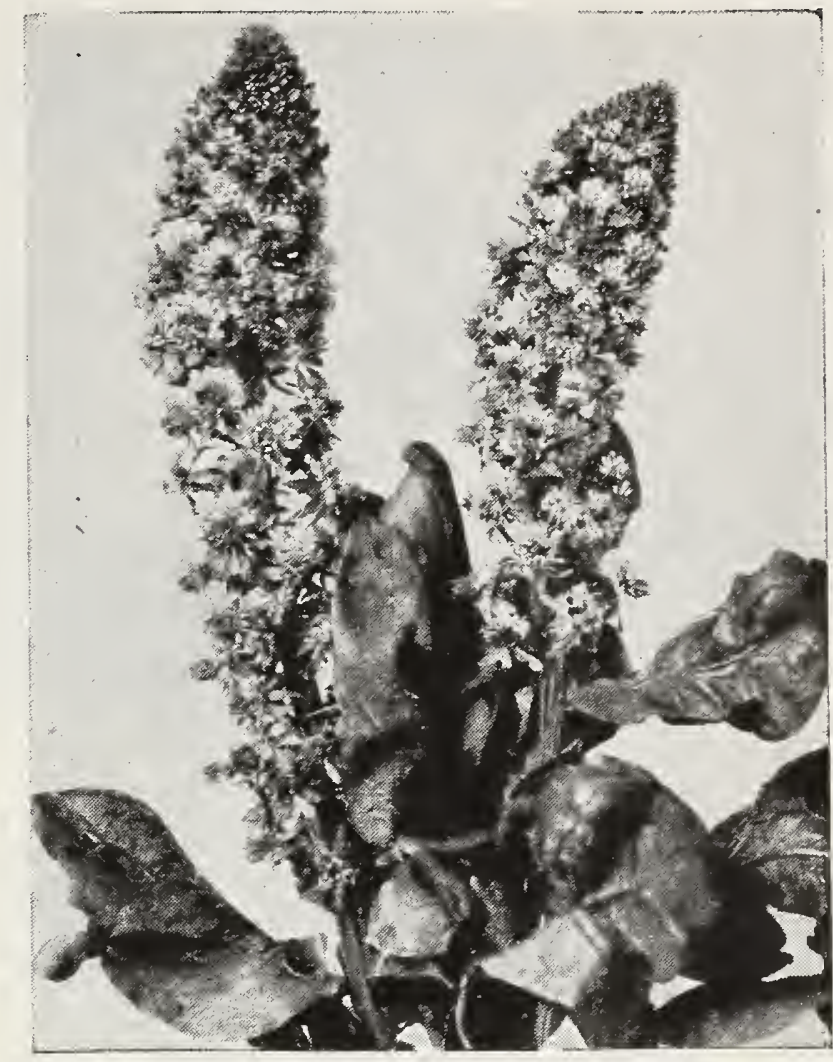

Modest, jet indispensable Sweet Mignonette.

Mignonette

(Reseda), HA. Mignonette is the French for "little darling," and no more expressive word could be found for this modest flower. No garden is complete without it, no nosegay finished without its sprig of this sweet-smelling annual. Sowings made in April and July keep up a succession from early summer until frost; can also bo grown in pots for winter and early spring flowering.

Dobbies Giant. Red; enormous spike.

Pkt. 10 cts.; 1/4 oz. 50 cts.

Machet, Extra. Magnificent strain.

Pkt. 10 cts.; 1/4 oz. 50 cts.

Sweet-scented (Reseda odorata).

Pkt. 5 cts.; 1/4 oz. 15 cts.; oz. 40 cts.

MARSHMAIIOW. See Lavatera, opp. column.

MATRICARIA capensis f.-pl. (Feverfew). HHP. Double, white flowers on long stems. Pkt. 10 cts. munosA pudica (Sensitive Plant). HHA. Purplish flowers. When touched the leaflets close. Pkt. 10 cts.

\section{Marigolds}

HA. See also Calendula, pace 24. Both African and French Marigolds are popular, effeceasy culture, succeeding best in a light soil and sunny exposure. The former have uniformly largo yellow, or orange flowers and are well adapted to large beds or mixed borders; the latter are dwarfer, with beautifully marked blossoms, and better for small beds and pot culture.

(Our Seed is Extra rine)

\section{French (Tall and Dwarf)}

Mixed, Tall Double French. Fine mixture of the tall French sorts in yellow brown and striped. Good for cutting. Pkt. 10 cts.

Mixed Dwarf Double French Marigolds. Very eIfective and long flowering. The dense bushes, not over 12 inches high, are unequalled for borders. Mixed colors. $1 / 4$ oz, 20 cts.; pkt. $10 \mathrm{cts}$

French Iegion of Honor (Little Brownie). A dwarf, bushy variety especially desirable for borders. The one-foot plants bear many singla, rich golden flowers with a garnet blotch in the center of each petal. 1/4 oz. 25 cts.; Pkt. 10 cts.

Double Iegion of Fonor. (Electric Light.) New: extra fine. Pkt, 10 cts. $1 / 4$ 0z, 35 cts.

Pigmy Marigold (Tagetes signata pumila). Forms a pretty little dwarf, compact round bush with slender fern-like foliage and an abundance of dainty single golden flowers. Splendid border subject. Plit. 10 cts. 


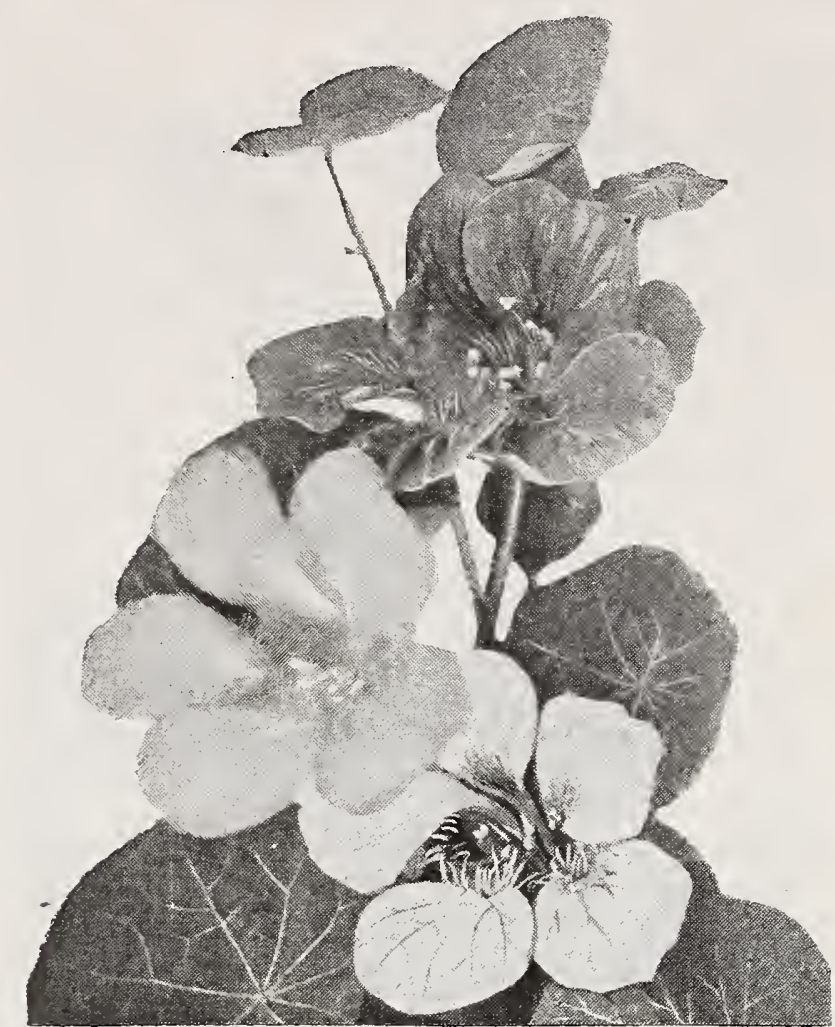

"Nasturtiums like circus clowns Dance about in gaudy gowns."

\section{MARIGOLDS-Continued Double African (Tall)}

Giant Iemon Queen. Fxtra Fine. This highly meritorious strain of the African Marigold is grown specially for us by a specialist who selects only the finest blooms and plants of un usually good constitution for seeding purposes. Height, $21 / 2$ feet. Pkt. 25 cts.; 1// oz. $\$ 1.00$.

Ciant Iemon Queen. Very good strain.

Pkt. $10 \mathrm{cts}$; $1 / 4$ oz. 35 cts

Giant Orange Prince. Extra Fine. The darker form of the preceding variety. Height, $2 \frac{1 / 2}{\text { feet }}$ Finest strain procurable; seed saved from show flowers. Pkt. 25 cts.; $1 / 4$ oz. $\$ 1.00$.

Giant Orange Prince. Very good strain. Pkt. 10 cts.; $1 / 4$ oz. 35 cts.

Mixed Orange and Iemon.

Pkt. 10 cts.; 1/4 oz. 25 cts.

MOMORDICA. HA Handsome, tendril climbers, bearing odd-shaped fruit.

Balsamina (Balsam Apple).

Pkt. 10 cts.; 1/4 oz. 25 cts.

Charantia (Balsam Pear). Pkt. $10 \mathrm{cts.;} 1 / 4$ 0z. $25 \mathrm{c}$.

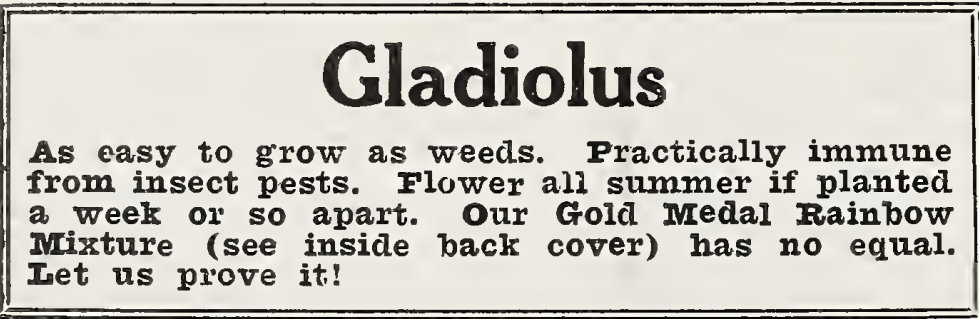

Hedges From Seed-Very Suitable

Marvel of Peru (Four o'Clock), Salvia (Flowering Sage) Kochia (Summer Cypress or Burning Bush), Ricinus (Castor Oil Plant).

\section{Monin Glory HA of the caster} Morning-Glory in the open ground when the weather has become warm and settled. "Morning Glories one by one Wake to greet the rising sun."

Mixed Giant Japanese. Pkt, 10 cts.: oz, 40 cts. adxed Climbing (Convolvulus major). Extra fine. Pkt. 5 cts.; $1 / 4$ oz. 15 cts.; oz. 40 cts.

See also Ipomoea, page 29 .

Tou will always find a cordial welcome at "Tour Friendly Seed Store" whether you come to parchase or complain.

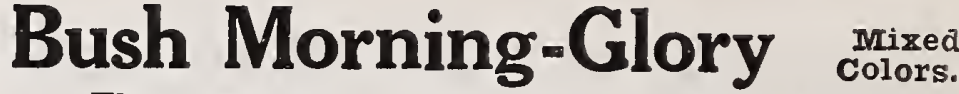

These divarf or bush morning-glories are very desirable for beds and borders. They form plants $11 / 2$ to 2 feet in diameter and 1 foot They bloom most profusely and closely resemb their climbing sisters, but the flowers remain open practically all day. Try them.

Plkt. 10 cts.; 1/4 oz. 15 ct's.; oz. 40 cts

\section{Wilson's \\ Famous Nasturtiums на.}

\section{THEY BLOOMI AIL SUMLMIR.}

All 10 cts. per pitt., 25 cts. per oz.

\section{Tom Thumb Dwarf}

Wilmon's Special Rainbow Mixture. Made up from many named varieties, embracing all color com binations known in this increasingly popular and easily grown annual. Included in this extra selection are the variegated leaved and ivy-leaved sorts seldom found in other mixtures.

Pkt. 10 cts.; oz, 25 cts. $1 / 4$ lb. 75 cts.; lb $\$ 2.50$ Chameleon, Mixed. Richly colored flowers on same plant.

Cloth of Gold. Fiery crimson; golden leaved. Crystal Palace Gem. Orange-yellow, garnet blotches. King Theodore. Deep maroon.

Salmon Queen (Vesuvius). Salmon rose.

Empress of India. Crimson, dark foliage.

Collection: 1 Pkt. each 8 named Dwarf Sorts, 75 cts.

\section{Tall, or Trailing}

Wilson's Superb Mixture. From named sorts and in cluding all colors and shades. Like our Rainbow (Dwarf) Mixture in a class by itself. Pkt 10 cts.; oz. 25 cts.; $1 / 4$ lb. 75 cts.; lb. $\$ 2.50$.

Chameleon (Coquette). Rare colors in mixture.

Cloth of Gold. Fiery crimson; golden leaved.

Salmon Queen. Salmon rose.

Butterfiy. Yellow spotted salmon.

King Theodore. Black.

Collection: 1 Pkt. each 8 named Tall Sorts, 75 cts INEMOPHIIA Insignis Blue (Love Grove). HHA. Compact habit; blooms all summer if planted in a cool, shady place, and in not too rich soil. Pkt. 10 cts.

SOW WIISON'S "EVERGREEN" IAWN SEED if You Want a Fine Velvety Iawn. See page 3 .

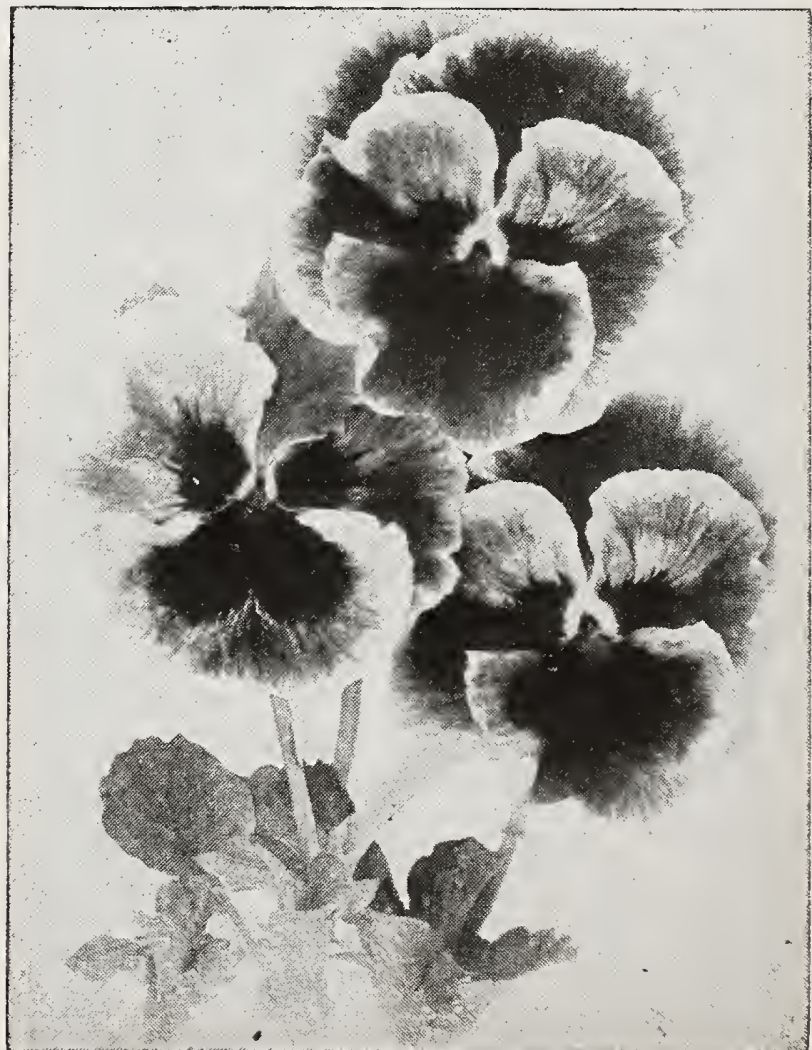

Wilson's Imperator Pansles for thourhts.

"Pansies looking grave and wise 


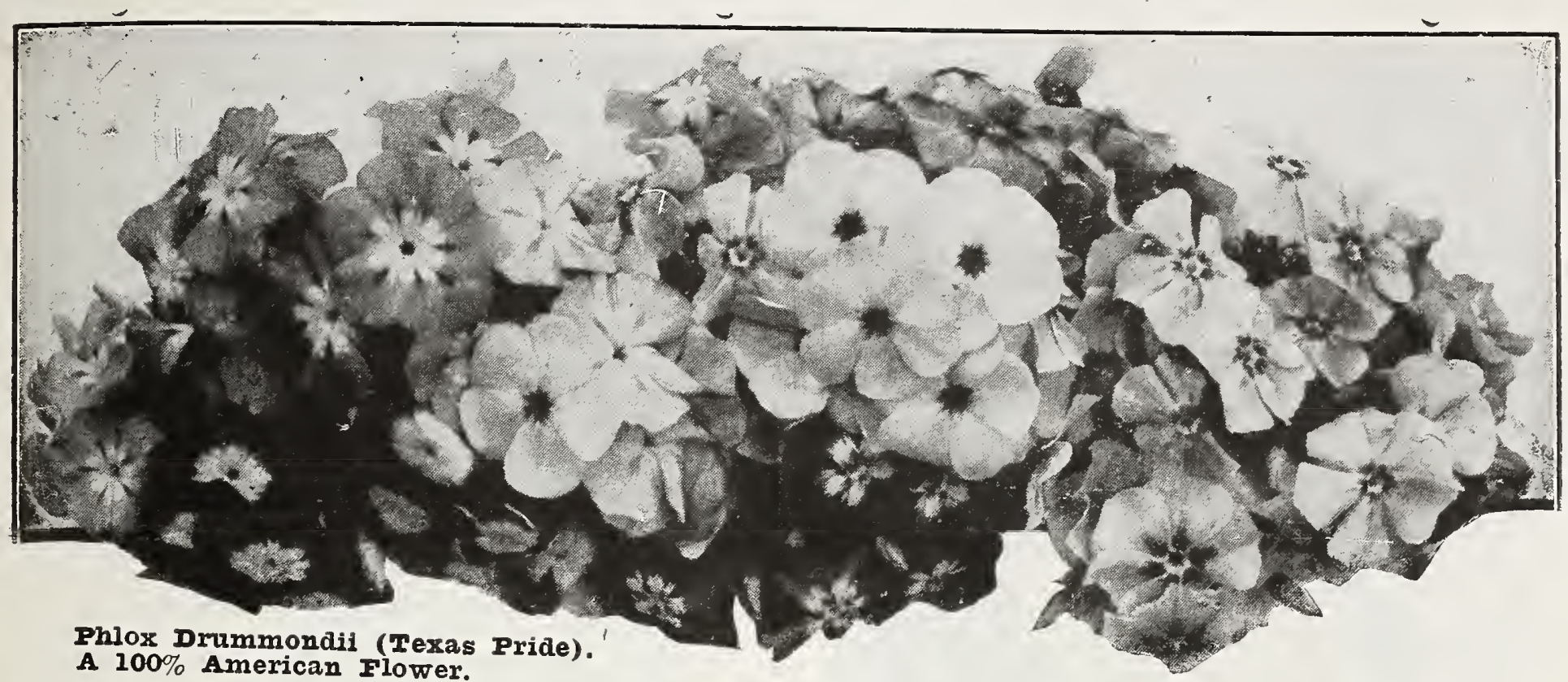

Nicotiana HA. Very showy and freecaring.

Carmine-Red (N. Sanderae). Pkt. 10 cts.

Sanderm Hybrids. Many colors. Pkt. $10 \mathrm{cts}$

Pure White (N. affinis). Fragrant; 4 feet. Pkt. 10c.

\section{Pansies}

HA. Seed sown in May will flower during late summer and autumn. For early spring fowering, sow in plants either August, and protect the young boughs. Soil should be light and well fertilizor The plants require plenty of moisture. Pansies do well in partial shade.

WISON'S DMPERATOR, MIXFD. Absolutely the richest mixture we know of; contains practically every combination of color and shade. Includes four- and five-blotched varieties orchid-flowered frilled sorts, and the selfs. Pkt. $25 \mathrm{cts}$.; 1/16 oz. $\$ 1.00$.

Butterfly, Mixed. A splendid mixture of largeflowered sorts. Not so fine as to colors and variations of colors as Wilson's Imperator (which is the finest obtainable), but still good. Pkt. 10 cts.

PASSION FIOWTR. TP. (Passiflora coerulea.) Sky-blue flowers. Fine climber. Pkt. 10 cts.

PENTSTEMON. (Beard Tongue.) HP. Persistent bloomer. Easily grown from seed.

Finest Mixed. Large Flowering Hybrids. Pkt. 25c.

Petunia HA. One of our most popular annuals, of the easiest culture, thriving in almost any soil and blooming all summer. Splendid for window boxes and for winter house plants save the weakest seedlings, for they produce the finest weakest
flowers.

Rosy Morn. Soft carmine-pink, white throat Pkt. 10 cts.

Carmen Sylva (Baby Blue so called, but color is Reddish Violet). Exquisite. Pkt. 10 cts.

Snowball. Pure satiny white flowers. Pkt. $10 \mathrm{cts}$. Violacea. Violet blue. Fine. Pkt. $10 \mathrm{cts}$.

Fine IMixed Colors. Pkt. 5 cts.; 1/4 oz. 30 cts.

Mixed, Inimitable Striped and Blotched. Pkt. 10c. California Giants, Mixed. Enormous flowers; colors unequalled. Pkt. $25 \mathrm{cts}$.

Double Fringed Mrixed. Extra choice strain, producing 40 to $50 \%$ double flowers. Pkt. 75 cts.

\section{Balcony Petunias}

A splendid large and free flowering type for window boxes, vases, hanging baskets, etc. The flowers average 3 inches across and make a very effective display over a long season.

Balcong Blue. Velvety indigo blue. Pkt. $25 \mathrm{cts}$

Balcony Rose. Brilliant rose-pink; very effective. Pkt. 25 cts.

Balcony White. The pure white form. Pkt. $25 \mathrm{cts}$. One packet each of the above 3 for $60 \mathrm{cts}$.

Show me a well-ordered garden and I will show you a well-ordered home
Phlox Drummondii HA one of the easiest plants that grown from seed. It will thrive in a $n$ grown from seed. It will thrive in any kind of light, rich loam. Seed may be sown in the open ground after danger of frost is past. A distinctly American flower blooming all summer.

\section{Large-Flowering Varieties}

White, Primrose, Purple, Chamois-rose, Scarlet. Each, pkt. 10 cts.

Collection: One plet. each of above 5 colors, 40 ct. Cholce rixed. Pkt. $10 \mathrm{cts}$.; 1/8 oz. $30 \mathrm{cts}$.

\section{Dwarf Phlox}

Compact habit. Fine for pots. 6 inches. Finest Mired. Pkt. 10 cts.

\section{Hardy Perennial Phlox}

Wuson's Superb Large-flowered, Mized, Pkt. 20 cts.

Din (Dianthus). HB1 and HP. One of our In most beautiful and best-loved flowers. Some are hardy biennials that bloom finely the first season. Seed can be sown under glass in spring, or in an open, sheltered bed Transplant the seedlings to stand 8 to 12 inches apart.

Chinensis, Double, Mixed (China Pinks).

Pkt. 10 cts.; $1 / 4$ oz. 25 cts.

Heddewigt (Japan Pinks). Large and brillant: often oddly edged and striped.

Single Mixed. Very choice. Pkt. 10 cts

Double, Mixed. Extra-fine strain. Pkt. 10 cts

wilson's Royal Pinks. Very large flowers of various colors, with crested surface to petals and white throats. Pkt. 10 cts.

Plumarius (Hardy Garden Pinks). HP. The fine, fragrant perennials of old-time gardens.

Pheasant's Fye. Single mixed. Pretty, fringed flowers. Pkt. 10 cts.

Semperflorens. Mixed. Perpetual pinks.

Pkt. 10 cts.

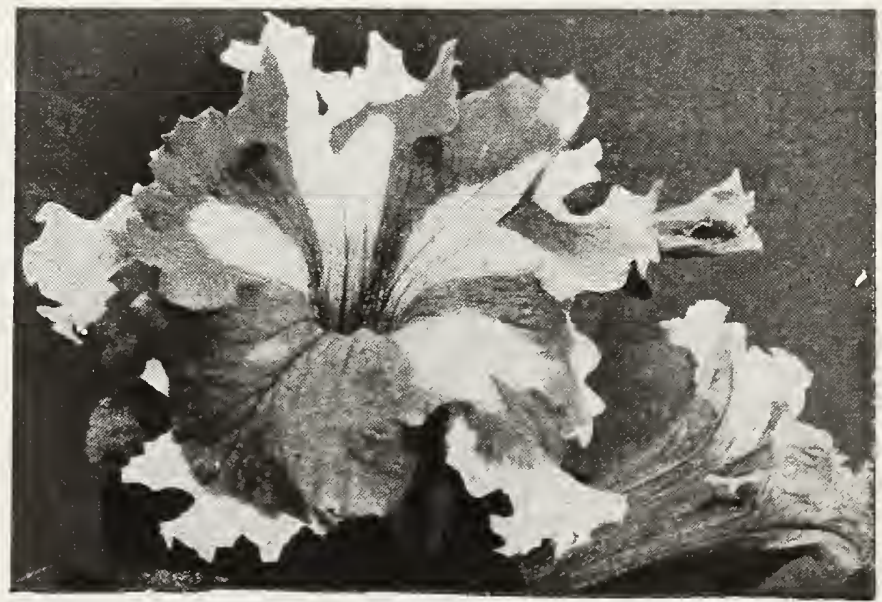

The richly colored, easily grown, long blooming drought-resisting Petunias. 


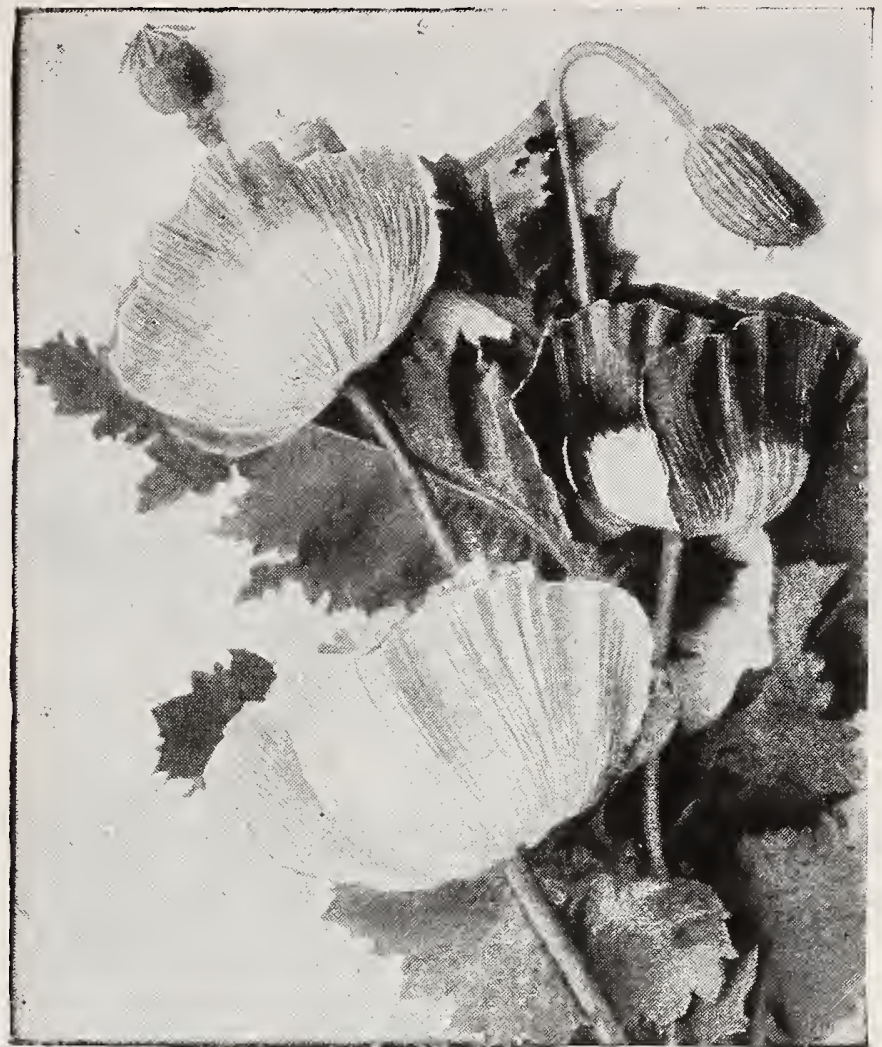

Bhirley Popples. Brilliantly colorful, tho fragllo as the wings of a butterfis.

Popies early and very thinly, preferably in early and very thinly, preferably in cloudy weather or after a shower. down firmly. Thin out to stand 3 or more inches apart. Make several sowings at intervals for a succession.

\section{Shirley Poppies HA.}

These interesting and lovely flowers, now growing in almost every garden in the world, are called Shirley poppies from the place of their origin. They originated in the garden of the Rev. William Wilkes, who was for many years vicar of Shirley, England, and who died only recently.

single Shirley. Choicest strain of seed of this lovely flower. Pkt. $10 \mathrm{cts}$; 1//4 oz. $25 \mathrm{cts}$.

Double Shirley. (Eldorado.) Beautiful new shades. Pkt. $10 \mathrm{cts}$.; 1/4 oz, $35 \mathrm{cts}$.

Double Annual Poppies HA.

Shrimp Pink. Exquisite. Pkt $10 \mathrm{cts}$

Cardinal. Very striking. Pkt. $10 \mathrm{cts}$.

arised Carnation-Flowered. Pkt. 5 cts.; oz. 25 cts.

\section{Poppies, Hardy Perennial}

Iceland Poppies (Papaver nudicaule). HP1. Mixed colors. These flower the first year from seed, blooming almost as quickly as the annuals. Pkt. $10 \mathrm{cts}$

Oriental Popples. Sow outdoors in early spring. When fall growth starts, transplant to permanent quarters. Deep Crimson ( $P$. bracteatum). Immense flow-

Orange-Scarlet (Rembrandt). Magnificent flowers of great substance, Pkt, 10 cts.

Mixed Hybrtds. Immense flowers. Pkt, $10 \mathrm{cts}$.

\section{Portulaca}

(Sun Plant: Rose Moss). HA. Of easy culture, thriving best in light loamy soil, and in a sunny situation. Fine for beds, edgings or rockwork. Mix the seed with three or four times its bulk of soil, to permit even distribution. Blooms all summer. Height 6 in. Single Irixed. Pkt. $10 \mathrm{cts}$; 1/4 oz. $30 \mathrm{cts}$.

Double INixed. Pkt', 15 cts

PRIMUIA (Hardy Primroses). HP. One of the best early spring-flowering plants. With slight protection they will stand the winter.

obconica, Mixed. TP. Fine for window gardens. Pkt. 25 cts.

Malacoldes. Lilac. flne Pkt, 25 cts

Sinensis. fimbrlata, Mixed. Pkt'.50 cts.

PUERARIA Thunbergiana (Japanese Kudzu Vino; Jack and the Beanstalk). HP. Rapid climber. Large foliage; rosy purple, pea-shaped blossoms in August. Pkt. 10 cts.
Prrethrom (Persian Daisy). HP. Hand. some herbaceous plants of easy culture.

Parthenifolium aureum (Golden Feather). Yellow foliage. Pkt. $10 \mathrm{cts}$

roseum hybridum. Large-flowering, single. Mixed. $2 \mathrm{ft}$. Pkt. $15 \mathrm{cts}$.

roseum hybrldum. Large-flowering, double. Mixed. Pkt. 25 cts.

D. (Castor-Oil Bean). HA. Ornamental Ricinus plants of stately growth, producing subtropical effects. Fine for annual subtropical effects. Fine for annual Zanzibariensis. Mixed. Very large leaves, some coppery bronze, changing to green. Pkt. 10 cts.: $1 / 2$ oz. 25 cts.; oz. 40 cts.

Rudbeckia ${ }_{\text {(Coneflower). }}^{\mathrm{HA}}$ free-flowering $\underset{\text { plant }}{\text { Haf }}$ of compact growth about 2 feet high forming a dense bush
and blooming profusely. Long stems; fine for cutting.

Bicolor Superba. HA. Golden yellow flowers spotted velvety brown at the base and with brown discs. Pkt. 10 cts.

Newmanil. HP. One of the finest autumn-flowering perennials. Large flowers with bright orange-yellow petals surrounding a large black zone. Pkt. 15 cts.

SALVIA (Flowering Sage). See page 34 . Salpiglossis $\begin{aligned} & \text { Beautiful, orchid-like flowers: } \\ & \text { from early summer until fall: }\end{aligned}$ of easy culture. Sow early in spring in a hotbed or window, and transplant outdoors after danger of frost is past. Finest Colors Mixed, Emperor. Pkt. $10 \mathrm{cts}$ grandiflora mixed colors extra. Pkt. $10 \mathrm{cts}$ Schizanthus $\begin{aligned} & \text { (Butterfiy Flower) HA. HA. } \\ & \text { Erect grower. Wonderfui } \\ & \text { coloring; of easy culture: }\end{aligned}$ fine for cutting; $11 / 2 \mathrm{ft}$.

Grandiflora, Mixed. Splendid. Pkt. $10 \mathrm{cts}$.

Wisetonensis, Mixed. All colors varying from white with yellow eye to bright rose with brown centers. Pkt. 10 cts.

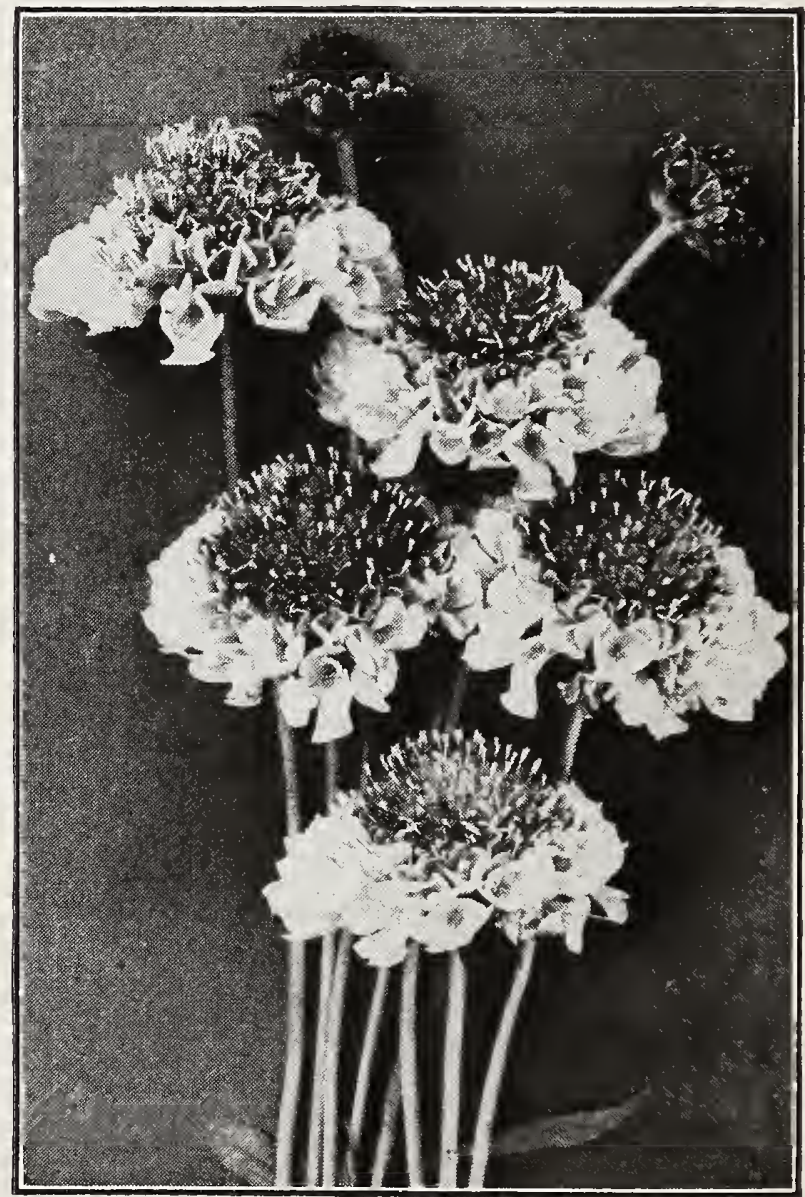

Scablosa. See page 33.

The brighter hues of the Mourning Bride belle It name while the darker, rlcher color are splendid in their depth and mystery. 


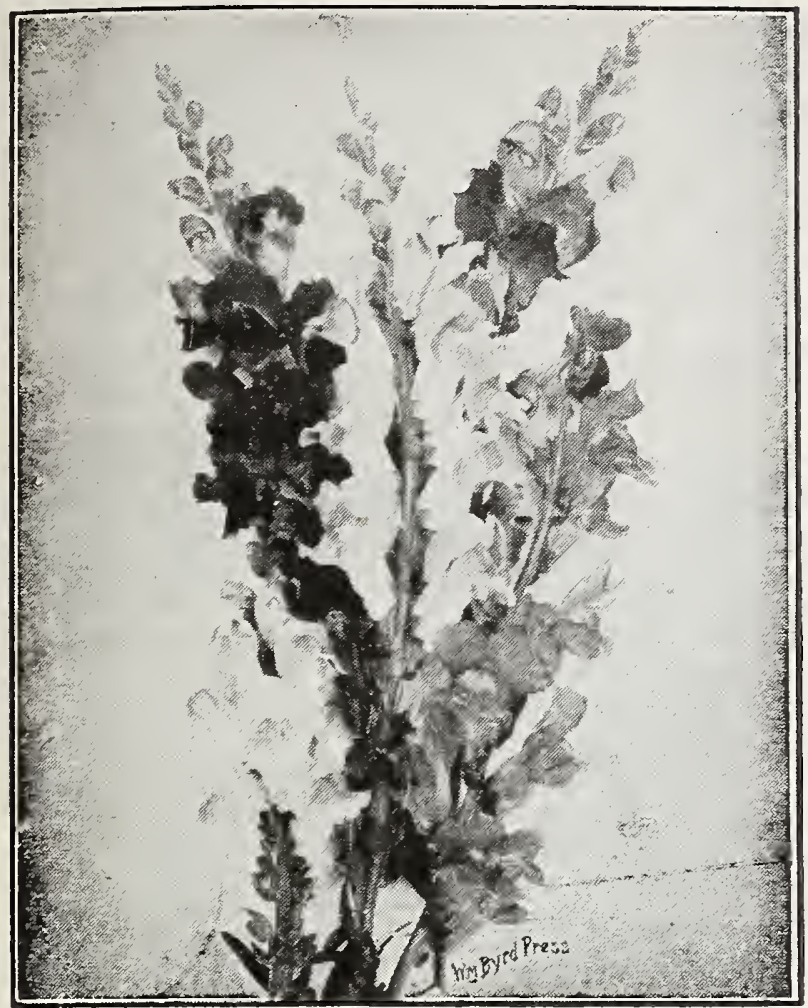

Snapdragon.

It seems to speak of noble birth and Aristocratic lineage, though any one can grow themand everybody should.

Scabiosa

(Mourning Bride, or Pin-Cushion Flower.) HA. Another of the "old reliables." Seeds of the annual sorts can be sown as soon as danger from frost is past. Growing about $21 / 2$ feet high, they come into bloom early in July and remain so till hard frosts. The exquisitely shaded flowers on long stems keep in perfect condition, when cut, for several days.

\section{Annual Large-Flowering}

Fing of the Blacks. Velvety black-purple Pkt. 10 cts.; $1 / 4$ oz. 30 cts.

Azure Fairy. A clear lavender-blue. Pkt. 10 cts.; $1 / 8$ oz. 30 cts.

Crimson. Beautiful. Pkt. 10 cts.; 1/4 oz. 30 cts. Snowball. Pure white. Pkt. 10 cts.; 1/4 oz. 30 cts. Rose. Rosy-pink. Pkt. 10 cts.; $1 / 4$ oz. 30 cts.

Mixed Scabiosa. All colors. Pkt. 10c; 1/4 oz. $25 \mathrm{c}$.

Collection: 1 Pkt. each of above 5 separate sorts, $45 \mathrm{c}$.

\section{Hardy Perennial Scabiosa}

Scabiosa Caucasica (Blue Bonnet). Extremely handsome and especially good for cutting. flowers soft lavender-blue. Oz. 40c; pkt. $15 \mathrm{c}$.

SFISTTIV PIANT. See Mimosa, page 29.

\section{Snapdragon}

Also called Little Bo-Peep. (A $\mathrm{ti} r \mathrm{~h}$ in $\mathrm{m}$ ) HP1. Within the last few years Snapdragons have become immensely popular. This is not to be. wondered at, as, whether used for cutting or for show in the garden, they are one of the most valuable flowers which can readily be grown from seed. We offer two distinct types, the large-flowering, tall-growing or giant, and the equally largeflowered, half dwarf variety. Seeds sown out of doors the first week of May came into bloom early in July, remaining in full flower until November. For earlier flowering, they may be started indoors or in a frame in March, transplanting them to the open when the weather is suitable.

\section{GIANT VARIETIES}

All 10 cts, per pit.; 40 cts, per $1 / 80$ os. Of all growth, very large individual flowers Height, 3 feet.

Apple Blossom. Rose sharing to pink, yellow throat. Charming sort.
GIANT SNAPDRAGONS-Continued.

Crusader. Velvety reddish maroon with crimson cast Fine.

Bunch of Iilac. Violet purple; immense flowers Striking.

Golden Queen. Deep yellow flowers of great substance. Extra.

Purple King. Rich.

Canary Bird. Canary-yellow.

Snowflake. Pure white, yellowish throat.

Sunshine. Rich bright yellow with a touch of pink in the tube. Distinct.

Wallfower. Rich deep coppery crimson, immense spikes. Very unusual.

Copper Iing. Coppery-scarlet.

Collection: 1 pkt. each above 10 extra fine sorts, $90 \mathrm{c}$. Glant Inised. All colors.

\section{Large-Flowering Half Dwarf Varieties}

Best type for bedding. Height, 18 inches. All $10 \mathrm{cts}$. per plst.; 1/8 0z. $25 \mathrm{cts}$.

Black Prince. Dark crimson

Canary Bird. Lemon-yellow. Fine.

Climax. Orange shading to yellow in lip. Splendid. Carmine Queen. Brilliant rose carmine. Fine.

Empress. Rich velvety crimson. Exquisite.

Defiance, Fiery scarlet.

Mauve Beauty. Rosy mauve.

Rose Dore. Golden-rose. Distinct.

Purity. Pure white. Very chaste.

Silver Pink. Pearly pink self. Very dainty.

Collection: 1 pkt. each above 10 sorts for $90 \mathrm{cts}$.

Mired Ealf Dwarf Sorts. All colors.

SNOW ON THE MOUNTAIN. See Euphorbia, p. 27

\section{Stocks}

HA. These popular flowers are eag1ly grown, and are so highly fragrant and of such great beauty, and have so many good qualities, that they deserve a place in every garden. They should be given good rich soil to grow in, and will amply reward good treatment with remarkably large pyramids of bloom. The flowers represent a great diversity of color. The Tall Perfection and Beauty Stocks are great improvements over the Gilliflowers of the olden times, the flowers being much larger and more densely double, and there is also a much larger variety of colors and shades than there used to be.

\section{Wilson's Cut and Come Again, or Improved Giant Perfection Stocks}

All $\operatorname{sam} \theta$ price 25 cts. per plat.; $\$ 1.00$ per $1 / 80$ os.

Of splendid, pyramidal growth, freely branching from the main stem, giving an abundance of large spikes of double flowers from early summer unti] fall; used largely for cutting. 2 feet.

White (Princess Alice).

Crimson (Triumph).

Dark Blue.

Canary-Yellow (Creole). Flesh Color.

Featham Beauty. Rose shaded, terra-cotta. Collection: 1 plst. each of above 10 colors, $\$ 2.00$

\section{Giant-Flowering Beauty Stocks}

A11 same price-25 cts per pkt.; $\$ 1.00$ per $1 / 8$ oz.

A magnificent, recently developed strain of early flowering winter or Brompton Stocks, forming much branched plants about 2 feet high, and having num. erous spikes of very large, double, delightfully fra. grant flowers; they are of special value as potplants for greenhouse decoration and for cutting during the dull winter months; for this purpose seed should be sown from July to September; if sown in February or March, will produce plants that wll] bloom from mid-summer to frost.

Almond Blossom. White, shaded carmine.

Beauty of Nice. Delicate pink.

Mont Blanc. Purest white.

Monte Carlo. Canary-yellow.

Queen Alexandra. Beautiful lilac.

Summer NIght. Rich deep blue.

Souvenior of Monaco. Brillant crimson.

Abundance, Carmine-rose.

Collection: 1 plet. each of above 8 colors, $\$ 1.75$.

\section{Dwarf Mixed Ten-Week Stocks}

For outdoor sowing for beds and borders. Pkt. 10 cts.

SWrFT ROCKrT (Hesperis). HP. Also known a Dame's Rocket; grows 2 to 3 feet high with spikes of showy, fragrant flowers. Parple. Dark shade. Pkt. $10 \mathrm{cts}$; $1 / 40 \mathrm{z} .25$ cte. White. Fine. Pkt. 10 cts.; $1 / \%$ oz. 25 cts. 


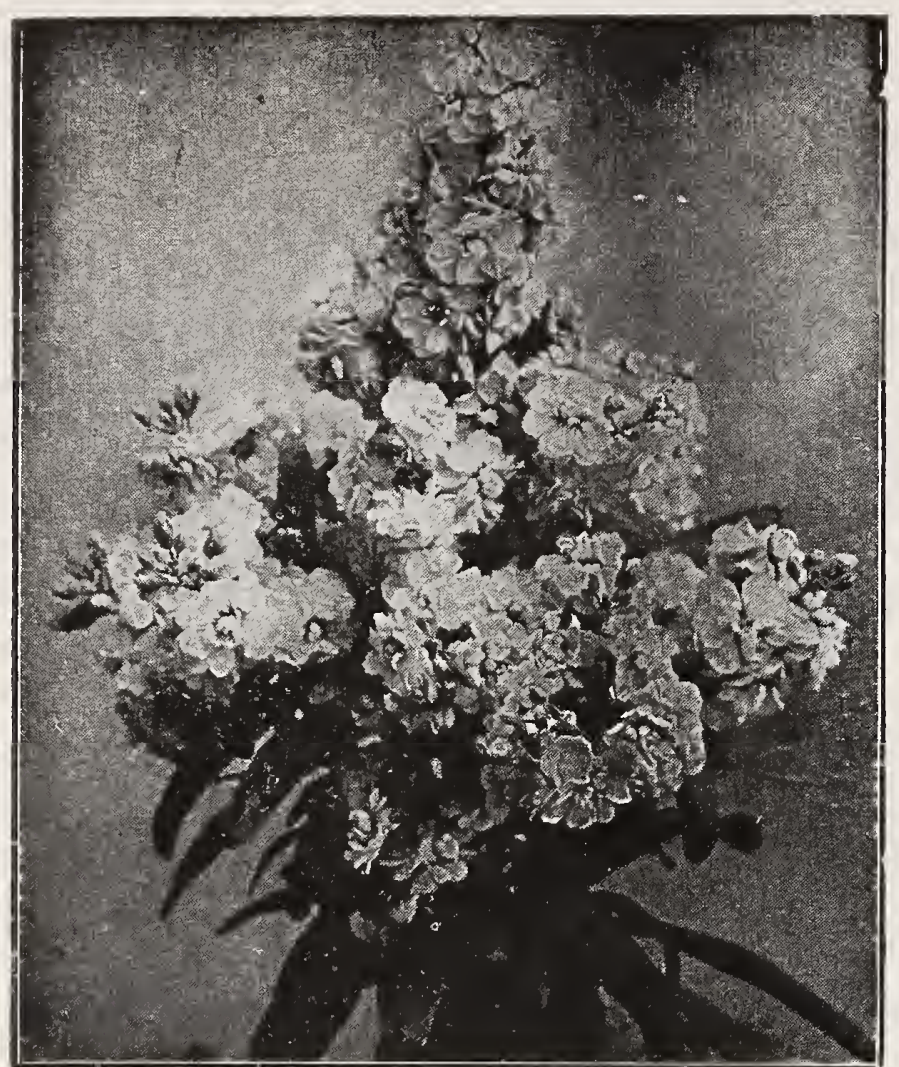

Glant Perfection Stocks.

So greatly improved as to be hardly recognizabie as the old-fashioned Gilliflower of grand. mother's garden. See page 33 . Sunflawers prise plants of majestic growth and immense showy beries, woodlands, flowers, suitable for shrubgardening; the dwarfer kinds, with smaller flowers, are charming when grouped in mixed flower borders.

\section{Large-Flowered Tall}

Annuus Purpureus, Gaillardia-Flowered, or Red Sunflower, 4 to $8 \mathrm{ft}$ Some flowers of a rich chestnut-red color, others tipped with yellow and others slightly washed with red. Pkt. 10 cts.

Globosus Fistulosus. Fl. Pl. $6 \mathrm{ft}$. Double globe or dahlia sunflower. Flowers a rich saffron color. Pkt. $10 \mathrm{cts}$; $1 / 4$ oz. $20 \mathrm{cts}$.

Russian Mammoth. Single, of gigantic dimensions. Pht. 5 cts.; oz. 20 cts.

\section{Miniature-Flowered Sunflowers-Single Average Feight 4 Feet.}

Spreading bushes with small graceful foliage and multitude of small elegantly formed flowers, which are borne for a long time in succession, and are invaluable as cut-flowers.

Red Hybrids. Various shades of red; very effective. Pkt. 10 cts.

Stella. Large golden-yellow petals; small dark center. Pkt. 10 cts.; 1/4 oz. $25 \mathrm{cts}$.

Seedlings of stella. The prevailing colors are pale yellow, golden yellow and creamy white, some with black centers. All beautiful and fine for cutting. Pkt. 10 cts.; $1 / 4$ oz. 25 cts.

Orion. Petals rolled, resembling single Cactus Dahlia. Yellow, dark center. Pkt. 10 cts.

Diadem. Lemon yellow flowers with black centers. Fine. Pkt. 10 cts.; $1 / 4$ oz. 25 cts.

Double Miniature Sunflowers. Flowers borne very freely; bright golden yellow. Fine.

Pkt. 10 cts.; $1 / 4$ oz. 30 cts.

SUMMER CYPRESS. See Kochia, page 29.

SWEET SUITAN. See page 25.

SWEFT ROCKFT. See page 33 .

SWFET PrAS. See page 20.

TAGETIS SIGNATA PUIIIA. See IIarigold, p. 29

\section{SUNFLOWERS !}

Do you know them? Plant some of the Miniature Sorts listed on this page and you'll have:something extra fine for cutting.

Q 12 (Flowering Sage) HA Fasily raised Dal 12 from seed sown in February or March end of May.

in the greenhouse or hotbed. Transfer

scarlet (S. splendens). 3 feet. Pkt. 10 cts.; $1 / 8$ oz 40 cts.

Bonfire. Fine spikes. Pkt. $10 \mathrm{cts}$; 1/8 oz. $60 \mathrm{cts}$.

Zurich. Early dwarf; scarlet. Very compact. Pkt. 25 cts.

Blue (S. patens). TP. Erect spikes; 2 feet. Fl. 25 cts.

\section{Sweet William}

(London Tufts: Dianthus barbatus). HP. Well-known, attractive, free - flowering hardy perennials. It is much better to raise new plants from seed every season than to divide the old ones.

Giant White, Pkt. 10 cts.

Pink Beauty. Pkt. 10 cts.

Scarlet Beauty. Pkt, $10 \mathrm{cts}$.

1 pkt. each of the 3 colors for $25 \mathrm{cts}$.

Single IIixed. All colors. Pkt. 10 cts.

Single Mixed Dwarf. All colors. Pkt. 10 cts.

Double Mixed. Very fine strain. Pkt. 10 cts.

STOKFSIA cyanea (Cornflower Aster). HP. Cornflower-like blossoms from July until frost. 2 It

Iavender-blue. Pkt. $10 \mathrm{cts}$

Plenty of room for your car right at our door. Drive right up.

Vejoena HA. One of the finest bedding and border plants. Brilliant colored flowers.

Mammoth Strain. Produces immense flowers. White, Purple Shades, Scarlet Defiance, Yellow. Pink Shades, Blue Shades, and Very Fine Mixed. Each, pkt. 10 cts.

Collection: 1 pkt. each of the 6 colors for $50 \mathrm{cts}$

VINCA (Periwinkle). HA. Of easy cultivation. Hino for pots and bedding.

rosea. Rose. Pkt. 10 cts.

rosea alba, White, rose eye. Pkt. 10 cts.

alba pura. Pure white. Pkt. 10 cts.

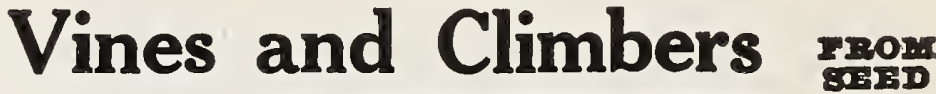

\section{See page 26}

Zinnia

One of our hobbies. See page 22 for wonderiul now sorts.

For a Permanent Velvety Iawn, sow WIISON'S EVFRGREFN IAWN SFED. seed page 3 .

XFRANTHEMUM. See Everlastings, page 28.

Wallflower

\section{A. \\ An}

Earliest Paris, Single Mixed. Pkt. $10 \mathrm{cts}$. Perennial Sorts.

rinest Single Mixed. Pkt. $10 \mathrm{cts}$.

Pinest Double Mixed. Pkt. $25 \mathrm{cts}$.

\section{FUOWERS OF MUCH IIFRIT THAT SHOUID} BE BETTER KNOWN. AIL ARE EASY

$$
\text { TO GROW. }
$$

Arctotis. Page 23. Dimorphotheca. Page 27. Didiscus. Page 27. Iavatera. Page 29. Rudbeckia. Page 32. Bush Marning Glory. Page 30.
Iove-in-a-mist. Page 29. Schizanthus. Page 33. Miniature Sunflowers. Opposite column. 


\section{Summer Flowering}

GLORIOUS GLADIOLUS Everybody's Flower Because

Plant a few bulbs each week from April to end of July and provide wonderful cut-flowers from July to Oct.

CUITURE-Any good garden soil, thoroughly prepared and manured, is suitable. Bonemeal or Four Seasons Fertilizer are particularly good. (See page 4.) If the soil is stiff, fill drills with sandy loam, mixed with sifted ashes.

Gladioli do best in full sun. Plant in rows, 6 inches apart in the row, and 6 inches deep, rows 12 inches apart. Mass planting in beds, setting bulbs 5 to 6 inches apart in either direction, will be found highly desirable. Frequent cultivation is advisable. Water copiously and as the flower buds begin to form apply liquid manure for best results. Take up bulbs in fall before ground begins to freeze and put in a warm sunny place, for a few days, to dry. Remove stems by cutting them off six inches above bulb, tie in bunches and hang in a dry cool place till spring or store in paper bag's.

In cutting Gladioli for the house, it is best to cut the spikes as soon as the first one or two flowers are open. The remainder will open in the house. If you take pains each clay to remove the faded flowers, cut a little off the end of the stem and change the water, a spike will last a week or ten days.

\section{Wilson's Gold Medal Rainbow Mixture}

Most gladioli mixtures are composed of a number of odd (mostly cheap) varieties thrown together into one container and sold in that way. That's why mixtures are usually a disappointment. You never know what you get. Our nixtures are taken from named sorts-12 separate named varieties in this particular offering-so that the pur chaser is absolutely sure he is getting a real mixture. Wilson's G. M. R. Mixture positively contains sorts listed as high as $\$ 2.00$ per dozen. No other mixture we ever heard of can equal it.

We have made arrangements for an ample supply of bulbs. So we can fill all orders for this superb assortment, but don't delay ordering if you want to be sure of the original mixture.

Prices of Wilson's G. M. R. Gladioli Mixture

Per dozen, $\$ 1.00$; per $100, \$ 7.50$ (25 at 100 rate). Delivered anywhere in the United States.

Per dozen, 85 cts.; per $100, \$ 6.00$ (25 at 100 rate). If carried away.

\section{Glorious Gladiolus in the Best Named Varieties}

\section{THE CREAM OF AMERICA'S BEST}

Six of a kind at dozen rates; 25 of a kind at 100 rate.

Letters following names of varieties indicate season of blooming thus: (E.) - Very early. (E.M.) - Early midseason. (M.)-Midseason. (L.M.)-Late midseason. (L.)-Very late.

AMERICA. (L.M.) Delicate lavender-pink flowers of large size, borne on strong stems, and well placed; splendid habit. Very popular cut-flower variety. 6 cts. each; 60 cts. per doz.; $\$ 4.00$ per 100 .

ANNA FBERIUS. (M.) Dark velvety purple, throat deeper shade; very large flowers on tall, fine spikes. A very fine variety in an unusual color. 16 cts. each; $\$ 1.75$ per doz.; $\$ 12.00$ per 100 .

BARON HUTOT. (M.) Rich, royal violet-blue. One of the finest of its color. Flowers are medium in size, well placed, and borne on strong spikes. 16 cts. each; $\$ 1.75$ per doz., $\$ 12.00$ per 100 .

CATHARINA (New). (E.) A most attractive sort. The color is a wonderful light grayish blue lower petals a little deeper blue with brownish red spot at throat. 16 cts. each; $\$ 1.75$ per doz. $\$ 12.00$ per 100 .

FIORA. Exquisitely beautiful clear canary yellow flowers of immense size and with very little markings. Sure bloomer. The best yellow in our judgment. 16 cts. each; $\$ 1.75$ per doz.; $\$ 12$ per 100

HAIIEY. (E.) The flower's are large, beautiful salmon-pink, with creany white blotch in throat. One of the earliest-blooming varieties. 6 cts. each 65 cts. per doz.; $\$ 4.50$ per 100 .

INDEPENDENCE. (M.) Rich coral-pink with darker throat. A fine large flower of good substance. 9 cts. each; 90 cts. per doz.; $\$ 6.00$ per 100 .

IE MARECHAT FOCF. (E.M.) A beautiful light salmon-pink; will be more generally grown when better known. The flowers are extra large and of unusual substance. An improved America. 9 cts. each; 90 cts. per doz.; $\$ 6.00$ per 100 .

MARY FFNNFI. (M.) A beautiful shade of deep lavender, with petals penciled primirose. Flowers are large in size, borne on svikes medium in height. An excellent variety for contrasting with pale pink and primrose sorts. 14 cts. ea.ch: $\$ 1.40$ per doz.; $\$ 10.00$ per 100 .

IIRS. FRANCIS KING. (M.) Brilliant flamingopink, blazed vermilion. Splendid for mass effects. Hlowers are large. on strong. tall spikes. 9 cts. each; 90 cts. per doz.; $\$ 6.00$ per 100.
MRS. FRANK PENDIFTON. (M.) Salmon-pink which extends to reverse side of the petals as well as in the center, with a rich, deep maroon blotch on the three lower petals. Flowers are wide open and well placed on strong spikes. 9 cts. each; 90 cts. per doz.; $\$ 6.00$ per 100

IMRS. DR. NORTON. (E.) Pure, soft white, with tips of petals suffused LaFrance Pink, soft sulphurous blotch. Wonderful variety; very large spikes. 16 cts. each; $\$ 1.75$ per doz.; $\$ 12$ per 100 NIAGARA. (E.M.) Soft primrose, faint lines of lilac in the throat, with purple stamens and pale carmine stigmas which add to its attractiveness. Flowers large, borne on tall spikes. 10 cts. each $\$ 1.10$ per doz.; $\$ 7.00$ per 100 .

PANAMA. (L.M.) Similar to America, but of a deeper shade of pure rose-pink. The flowers are large in size and well placed on tall, strong spikes. 9 cts. each; 90 cts. per doz.; $\$ 6.00$ per 100.

PEACs. (L.) Very large, white, with pale violet feathering on lower petals. Splendid bloomer. A beautiful variety that never disappoints. $10 \mathrm{cts}$. each; $\$ 1.10$ per doz.; $\$ 7.00$ per 100 .

PRINCE OF WAIES. (E.) The flowers are large and well placed and the color is a most charming coral-pink. It is a sport of Halley, but larger, taller and somewhat earlier. The delicate tint is practically without any throat markings. 10 cts each; $\$ 1.10$ per doz.; $\$ 7.00$ per 100 .

SCHWABFN. (L.M.) Pure canary-yellow, with a carmine blotch deep in the throat. Flowers are wide open, large in size and well placed on strong spikes of medium height. $10 \mathrm{cts}$. each; $\$ 1.10 \mathrm{per}$ doz.; $\$ 7.00$ per 100

WAR. (E.M.) The finest of its color. Flowers often measure 5 inches across, of a deep ox-bloodred, shaded crimson-black. They are well placed on spikes frequently attaining a height of 5 or 6 feet. A wonderful variety. 16 cts. each; $\$ 1.75$ per doz.; $\$ 12.00$ per 100 .

Collections: 1 each of the above 18 sorts (18 in all) for $\$ 1.75$.

Collections: 3 each of the above 18 sorts (54 in all) for $\$ 5.00$. 


\section{Strong Roots Ready from April 10th to May 5th}

Letters following names of varieties offered refer to types thus: (D.)-Decorative. (C.)-Cactus. (H. C.)-Hybrid cactus. (P.)-Paeony.

We list varieties that have proven their worth as gocd cut-flower sorts. We are not dealing in novelties or freaks that are usually a disappointment and abnormally high priced.

ATTRACTION (H. C.). Large flowers erect on strong

stems. Color clear lilac rose. $\$ 1.50$.

AZALEA (D.). Color soft yellow, tinged pink. Good stems and free in bloom. $\$ 1.00$.

BIANCA (H. C.). Medium flowers on fine stems. The color is a lovely lavender. $\$ 1.00$.

CALIFORNIA ENCHANTRESS (H. C.). The color is a beautiful pink and the stem excellent. Large blooms of good substance. $\$ 1.50$.

CARMENCITA (D.). A low growing plant; profuse bloomer. Yellow striped red; good stem. $\$ 1.50$.

CHARM (D.). A combination of burnt orange and copper, shading to yellow. Very profuse in bloom, with good long stems. $\$ 2.00$.

EDITH CAVEII (P.). A large flower carried erect on a long, strong stem. Old gold shaded reddish bronze. $\$ 2.00$.

EMPEROR (D.). Deep maroon purple blooms of large size with strong stems. $\$ 2.00$.
EIIZABETH BOSTON (P.). A very large flower of deep crimson shading to old gold at the tips. The best of stems and free in bloom. $\$ 3.00$.

GLADYS SHERWOOD (D.). Pure snow white blossoms of immense size on long, strong stems. The best white dahlia. $\$ 1.50$.

JUDGE MAREAiv (D.) Large flowers of perfect form with good stems. A combination of red. yellow, orange and gold. Very attractive. $\$ 1.50$. IATONA (P.). Large flowers with perfect stems. Color is orange yellow or buff. $\$ 1.00$.

MIT. SHASTA ( H. C.). Light shell pink shading to yellow. Large flowers on long strong stems. $\$ 2.00$. POLAR STAR (D.). A pure white flower of large size and good stem. One of the best whites. $\$ 1.50$ PRINCESS PAT (D.). A beautiful flower of soft old rose, with splendid stems. One of the best. $\$ 2.00$. RED CROSS (H. C.). Old gold shading to yellow, suffused scarlet. Large flower, good siem $\$ 1.01$ aMSON (D.). Deep garnet tipped white. Large with good long stem. Showy and fine. $\$ 1.50$.

\section{Special Fertilizer for Dahlias}

This special fertilizer has been used for several years by an expert grower who supplies us with many of our choicest Dahlias. It produces blooms
of the finest quality and should be used at the rate

of 2 pounds to each plant throughout the growing season, as a top dressing, after growth has well ten days or so. Prices 10 lbs. $\$ 1.50 ; 25$ lbs. $\$ 3.00 ; 50$ lbs. $\$ 5.50 ; 100$ lbs. $\$ 10.00$.

Heavy Chinese Bamboo Dahlia Stakes
Much stronger than wood and only about one-third the price.
Six feet long, 5/8 inch to $3 / 4$ inch diameter. Dozen, $\$ 1.25 ;$ per 100, $\$ 9.00$.
Used by many of the largest dahlia growers.

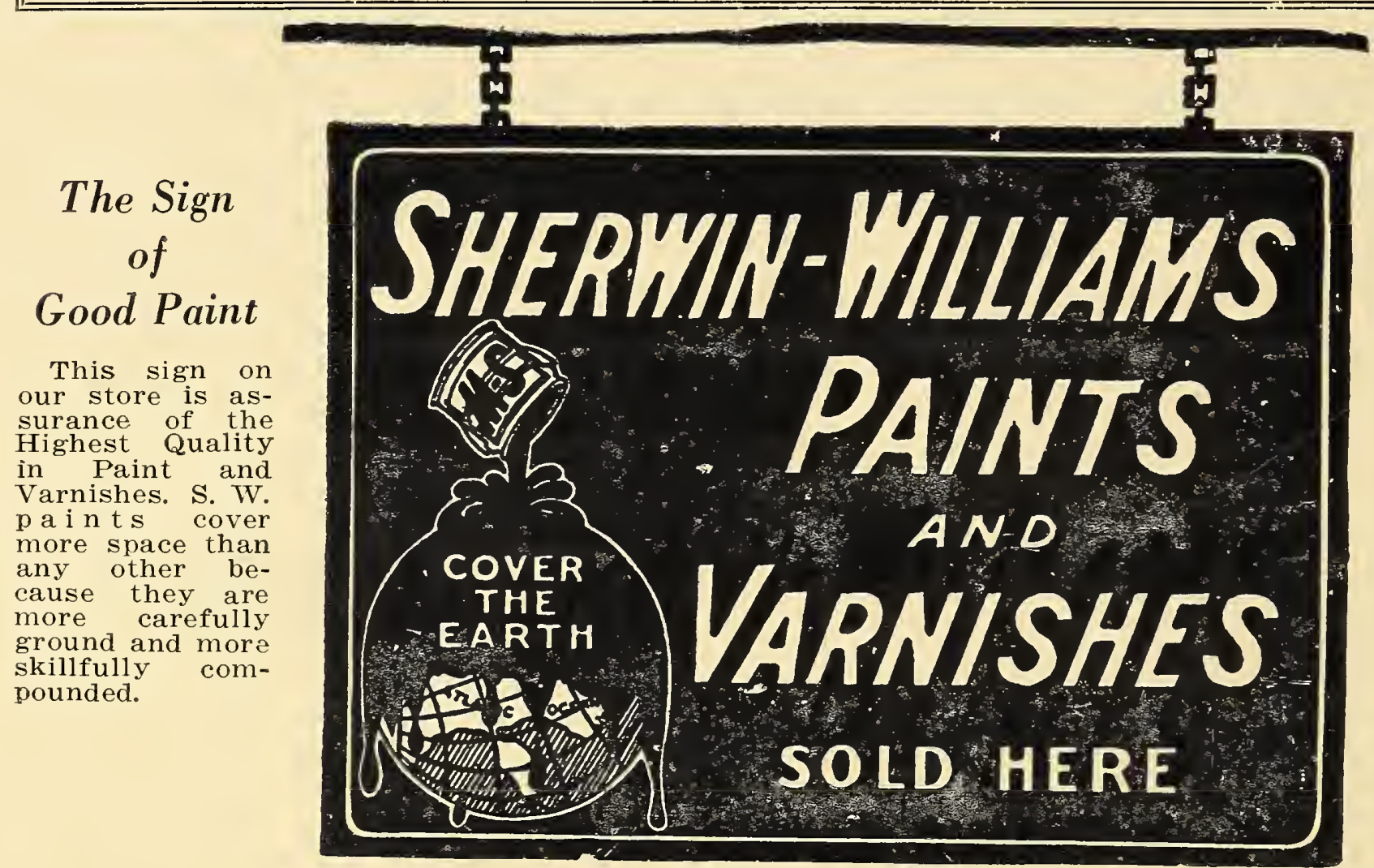

Sherwin-

Williams

Products

Paints

Varnishes

Enamels

Stains

Shellac

Driers

Fillers

Japans

Asphaltums

Greenhouse White

for frames and glass houses.

\section{A N N O U C E M E N T}

Property owners and others who use, or ought to use, paints and varnishes will be interested to know that we now have the

\section{Agency For}

For more than half a century this line has been the world's leader-that's why we salected it. And we are leaders in this locality-that's why the manufacturers granted us the agency for this well known line. A pretty good combination to do business with.

\section{SHERWIN-WILLIAMS PAINTS AND VARNISHES}

When you have need of anything in the paint and varnish line, you can depend upon full satisfaction and the most courteous attention here.

Our stocks

are new and our prices right.

ting Guide Free-Send for It.

J. J. Wilson Seed Co. Inc. 79 Orange St. (Close to Broad St.) Newark, N. J. 